
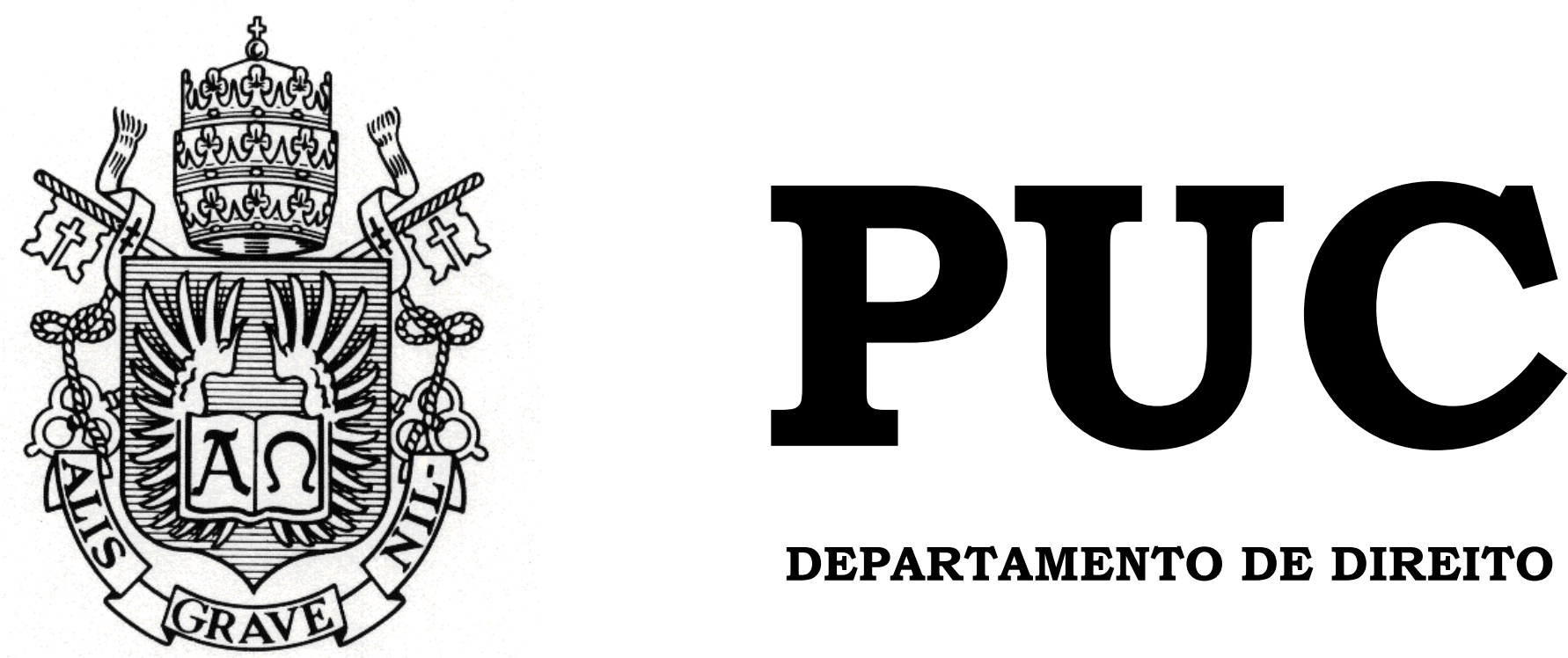

DEPARTAMENTO DE DIREITO

\title{
COISA JULGADA SOBRE QUESTÃO PREJUDICIAL À LUZ DO NOVO CÓDIGO DE PROCESSO CIVIL
}

por

JÚLIA DE OLIVEIRA RAVANELLI

ORIENTADOR: RONALDO EDUARDO CRAMER VEIGA

2019.1

PONTIFÍCIA UNIVERSIDADE CATÓLICA DO RIO DE JANEIRO

RUA MARQUÊS DE SÃO VICENTE, 225 - CEP 22453-900

RIO DE JANEIRO - BRASIL 


\title{
COISA JULGADA SOBRE QUESTÃO PREJUDICIAL À LUZ DO NOVO CÓDIGO DE PROCESSO CIVIL
}

\author{
por \\ JÚLIA DE OLIVEIRA RAVANELLI
}

Monografia apresentada

ao Departamento de

Direito da Pontificia Universidade Católica do Rio de Janeiro (PUC-Rio) para a obtenção do Título de Bacharel em Direito.

Orientador:

Ronaldo

Eduardo Cramer Veiga 


\section{DEDICATÓRIA}

À minha mãe, Sirinea

Ravanelli, minha estrela guia,

que brilha eternamente no céu. 


\section{AGRADECIMENTOS}

Ao meu pai, Sérgio Ravanelli, por toda o esforço e apoio em minha trajetória acadêmica, principalmente nessa fase turbulenta de final de curso. Sem você, não teria a força para conseguir seguir em frente.

À minha mãe, Sirinea Ravanelli, por todo amor e dedicação. Por você, tento ser uma pessoa melhor todos os dias da minha vida e não desisto dos meus sonhos. Avante!

À minha irmã, Mariana Ravanelli, formanda de engenharia civil, com uma brilhante carreira profissional pela frente, pelo incentivo diário para que eu me dedicasse inteiramente a cada um dos meus projetos.

Ao meu professor, Ronaldo Cramer, pela oportunidade e apoio na elaboração deste trabalho e por todo o conhecimento que obtive com as suas aulas.

Aos meus familiares, principalmente minhas queridas avós, Hermínia e Theresa, por serem minha base sólida. Pelo apoio e amor incondicional.

Ao meu namorado, Pedro Bruzzi, meu maior incentivador, que não poupou esforços para me ajudar em todas as etapas deste projeto.

A todos os meus professores, que tanto contribuíram para o meu desenvolvimento como futura profissional do direito.

A todos os meus amigos que dedicaram o seu tempo para me auxiliaram na realização do trabalho, sugerindo caminhos e fontes de pesquisa. 


\section{RESUMO}

O escopo do presente trabalho é analisar pormenorizadamente a extensão da coisa julgada após as alterações trazidas pelo novo diploma processual civil, essencialmente quanto à solução das questões prejudiciais incidentais. Para tanto, o trabalho foi dividido em três capítulos. O primeiro se voltará ao estudo do fenômeno da prejudicialidade, matéria insuficientemente tratada pela processualística nacional. O segundo tratará especificamente sobre coisa julgada, sendo destacado seu caráter constitucional e seu objetivo precípuo de assegurar a segurança jurídica nas relações processuais. Além disso, será apresentada uma síntese acerca do desenvolvimento do instituto tanto em sede doutrinária quanto legislativa. Por fim, o terceiro será iniciado com uma comparação crítica entre o regime da coisa julgada dos Códigos de Processo Civil de 1939 e 1973 e o atual diploma processual, com um enfoque no alcance da coisa julgada sob a questão prejudicial, sobretudo, a pretérita ação declaratória incidental. Neste ponto, o tema será realmente delimitado, destacando-se a coisa julgada comum, relativa à solução da questão principal e a coisa julgada especial, consoante à solução da questão incidental.

\section{PALAVRAS-CHAVE}

Coisa julgada - Questão prejudicial - Novo Código de Processo Civil. 


\section{SUMÁRIO}

INTRODUÇÃ O....................................................................................................8

CAPÍTULO 1. QUESTÃO PREJUDICIAL.............................................11

1.1. O conceito de prejudicialidade...........................................................11

1.2. Questões prévias preliminares e questões prévias prejudiciais...............14

1.3. Fenômeno da prejudicialidade: prejudicialidade lógica e jurídica.........19

1.4. Classificação das questões prejudicais: ponto, questão e causa..............25

CAPÍTULO 2. COISA JULGADA....................................................27

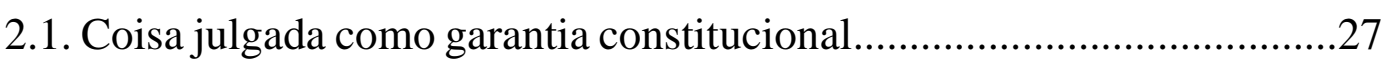

2.2. Reflexões doutrinárias sobre o conceito de coisa julgada e sua repercussão no direito positivado.................................................................28

2.3. Coisa julgada material e formal................................................................

2.4. Função positiva e negativa da coisa julgada...............................................40

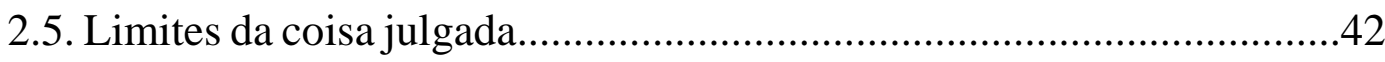

2.5.1. Limites objetivos da coisa julgada......................................................42

2.5.2. Limites subjetivos da coisa julgada.....................................................4

2.5.3. Limites temporais da coisa julgada....................................................47

CAPÍTULO 3. COISA JULGADA SOBRE QUESTÃo

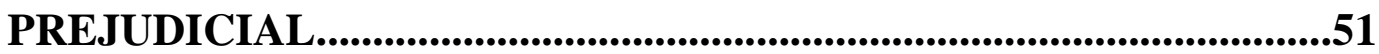

3.1. COISA JULGADA SOBRE QUESTÃO PREJUDICIAL NOS CÓDIGOS DE PROCESSO CIVIL DE 1939 e 1973 .......................................51

3.1.1. Panorama geral e ação declaratória incidental......................................51 


\subsection{COISA JULGADA SOBRE QUESTÃO PREJUDICIAL NO CÓDIGO}

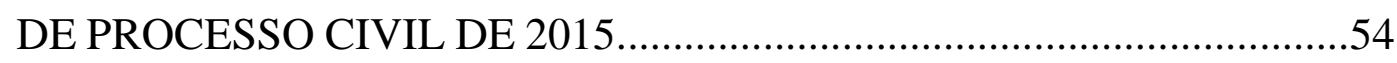

3.2.1. Distinção entre coisa julgada comum e coisa julgada especial............54

3.2.2. Requisitos para a formação de coisa julgada especial...........................55

3.2.2.1. Questão prejudicial expressamente decidida....................................56

3.2.2.2. Dependência para o julgamento do mérito.........................................59

3.2.2.3. Existência de contraditório prévio e efetivo......................................60

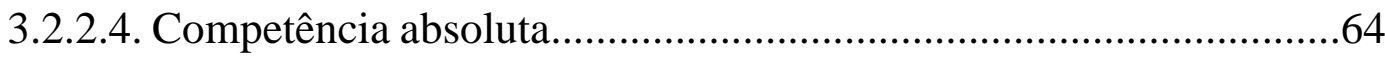

3.2.2.5. Ausência de restrições probatórias ou cognitivas..............................65

3.2.3. Diferença entre eficácia preclusiva e coisa julgada sobre questão

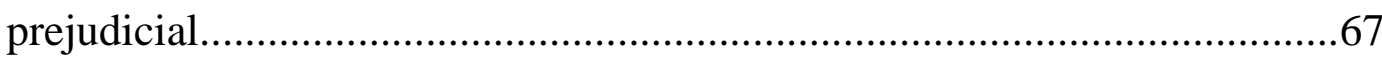

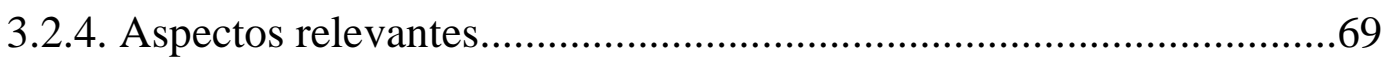

3.2.4.1. Desnecessidade de pedido declaratório expresso pela parte.............69

3.2.4.2. Sobrevivência da ação declaratória incidental.................................70

3.2.4.3. Desnecessidade de inserção no dispositivo da sentença.....................71

3.2.4.4. Submissão à remessa necessária.......................................................72

3.2.4.5. Impugnação da resolução da questão prejudicial e o interesse

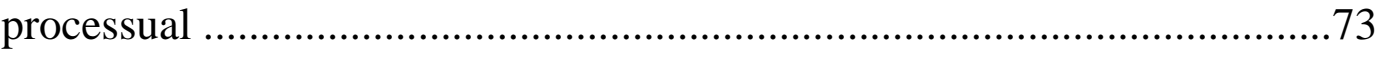

3.2.4.6. Controle da coisa julgada relativa à questão incidental.....................75

3.2.4.7. Questão prejudicial em relação a terceiros.........................................76

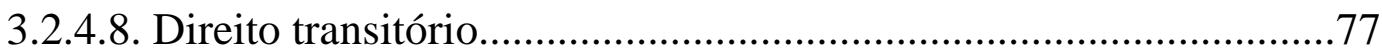

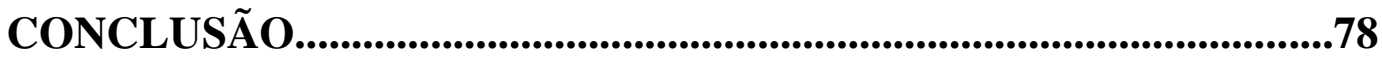

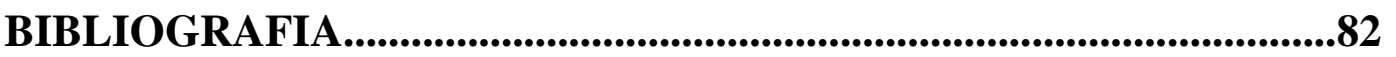




\title{
LISTA DE ABREVIATURAS
}

\author{
Art. - Artigo \\ CF - Constituição Federal \\ CPC - Código de Processo Civil \\ FPPC - Fórum Permanente de Processualistas Civis \\ STJ - Superior Tribunal de Justiça \\ STF - Supremo Tribunal Federal
}




\section{INTRODUÇÃO}

Alvo de discussão frequente da doutrina, a definição e os limites da coisa julgada foram substancialmente alterados pela nova sistemática processual assentada pela Lei 13.105/2015, o afamado novo Código de Processo Civil.

Sob a ótica de redução das vicissitudes do poder judiciário para a prestação jurisdicional efetiva, uma das inovações mais caras ao nosso ordenamento jurídico está relacionada à extensão dos limites objetivos da coisa julgada às questões prejudiciais resolvidas incidenter tantum no processo.

Em verdade, a abrangência dos limites objetivos da res iudicata sempre foi um tema muito controvertido pela doutrina processualista civil, principalmente no que tange às questões prévias indispensáveis ao deslinde do objeto principal do processo, as chamadas questões prejudiciais.

Apesar de sua indubitável importância na trajetória processual, o Código de Processo Civil de 1973 expressamente excluía tais questões da incidência da coisa julgada material. Em contrapartida, o legislador admitia que estas pudessem ser alcançadas pela imutabilidade e indiscutibilidade da coisa julgada através da postulação de uma ação - a ação declaratória incidental. $^{1}$

O novel diploma processual adotou tratamento diverso do diploma antecessor, permitindo a formação da coisa julgada sobre as questões prejudiciais, independentemente do pedido declaratório expresso.

A relatora-geral do Projeto do Código de Processo Civil de 2015, Teresa Arruda Alvim Wambier, entende ser a modificação especialmente útil para correção da incoerência consistente na existência de dois entendimentos

\footnotetext{
${ }^{1}$ CABRAL, Antonio do Passo. Coisa julgada. In: WAMBIER, Teresa Arruda Alvim et al. (coord.). Breves comentários ao Novo Código de Processo Civil. São Paulo: Revista dos Tribunais, 2015. p. 1.290 .
} 
distintos sobre a mesma causa petendi, proferidos em ações diversas. Para eminente jurista, a extensão da coisa julgada ampliada às questões incidentais propicia mais efetividade ao poder judiciário, atualmente sobrecarregado pela multiplicação exponencial de demandas a ele propostas. ${ }^{2}$

A Comissão do projeto de Lei, composta por onze juristas, reconheceu a inadequação em restringir a autoridade da coisa julgada apenas à solução da questão principal em si, visto que a cognição incidental sobre as questões prévias prejudiciais era profunda o bastante para tornar-se estável. ${ }^{3}$

Diante das particularidades de nosso ordenamento e dos princípios processuais, foram estabelecidos alguns requisitos legais para viabilizar a instauração de regime da coisa julgada sobre a questão prejudicial incidental. São eles: (i) expressa decisão da questão prejudicial; (ii) dependência de julgamento do mérito da decisão da solução da questão prejudicial; (iii) existência de contraditório prévio e efetivo; (iv) competência absoluta do juízo para decidir a referida questão como principal e; (v) ausência de restrições probatórias ou cognitivas.

Transparece, assim, o intuito do legislador em coibir a incidência da coisa julgada sobre pronunciamentos jurisdicionais que não fossem precedidos de debate efetivo entre as partes. De fato, não seria plausível que, ao final do processo, as partes se surpreendessem em vista de decisão que voluntariamente não pretendiam se vincular. ${ }^{4}$

De qualquer forma, é extremamente comum que uma inovação legislativa deste porte acomode percepções heterogêneas. A doutrina vem se debruçando sobre o tema, enfrentando alguns aspectos relevantes e,

\footnotetext{
${ }^{2}$ WAMBIER, Teresa Arruda Alvim. O que é abrangido pela coisa julgada no Direito Processual Civil Brasileiro: a norma vigente e as perspectivas de mudança. Revista de Processo. ano 39. v. 230. P. 75-89. São Paulo: Revista dos Tribunais, abr. 2014. p. 76.

${ }^{3}$ Ibid. p. 80.

${ }^{4}$ CABRAL, Antonio do Passo. Coisa julgada. In: WAMBIER, Teresa Arruda Alvim et al (coord.). Breves comentários ao Novo Código de Processo Civil. São Paulo: Revista dos Tribunais, 2015. p. 1.291 .
} 
inclusive, propondo requisitos supralegais à extensão da coisa julgada à questão prejudicial. 


\section{CAPÍTULO 1. QUESTÃO PREJUDICIAL}

A princípio, serão feitos alguns apontamentos acerca dos conceitos jurídicos da prejudicialidade e da coisa julgada, de forma a constituir um suporte teórico consistente para a apresentação do tema objeto do presente projeto. O primeiro conceito a ser abordado é o da prejudicialidade. Salutar destacar como ele se desenvolveu historicamente, a distinção entre questão prévia prejudicial e questão prévia preliminar; a prejudicialidade lógica e jurídica e a classificação das questões prejudiciais.

\subsection{O conceito de prejudicialidade}

A prejudicialidade não é nem deve ser relacionada com dano ou prejuízo. Na acepção ampla do termo, a prejudicialidade pode ser definida como "um fenômeno de influência”. Essa definição se correlaciona diretamente com a causalidade lógica e causalidade ontológica, ou seja, com as relações necessárias entre as coisas. ${ }^{5}$

No âmbito jurídico, a própria atividade jurisdicional pressupõe que o juiz siga uma cadeia causal lógica. Para que o magistrado profira a decisão, deve realizar uma operação mental, construindo um silogismo para chegar à sentença. No caminho transcorrido entre o ajuizamento da demanda e a prolação da decisão final, o magistrado se verá diante das mais diversas questões, que podem influenciar de alguma forma na solução do objeto litigioso. ${ }^{6}$ Dentre estas questões, há a questão prejudicial.

\footnotetext{
${ }^{5}$ LEITE, Clarisse Frechiani Lara. Prejudicialidade no processo civil. São Paulo: Saraiva, 2008. p. 21.

${ }^{6}$ ALVIM, Thereza. Questões previas e os limites objetivos da coisa julgada. São Paulo: Revista dos Tribunais, 1977. p. 13. No mesmo sentido, salienta Ada Pelegrini Grinover: "O raciocínio do juiz, em seu caminho lógico, é feito através de silogismos. E nas várias etapas de seu raciocínio, o magistrado terá de considerar e resolver todas as questões controvertidas com que se defrontar. $O$ julgamento da questão final só pode ser feito após a eliminação gradativa de todas as questões prejudiciais, assim chamadas por constituírem o antecedente lógico da decisão final e por serem julgadas antes que se possa decidir sobre a questão principal. A decisão de cada ponto prejudicial é, desse modo, uma espécie de degrau possibilitando outro passo rumo a decisão final."
} 
O fenômeno da prejudicialidade sempre foi notado pelos processualistas, porém estes só se voltaram a uma análise mais detalhada sobre a matéria em meados do século XX. No ano de 1904, foi publicada a primeira obra mais consistente sobre a prejudicialidade de autoria do jurista italiano Francesco Menestrina ${ }^{7}$. Influenciado por ela, Barbosa Moreira introduziu a temática na doutrina brasileira com a obra "Questões prejudiciais e coisa julgada" $\$$. 9

Barbosa Moreira se vê diante de contornos imprecisos sobre a temática da prejudicialidade não só na literatura processual, mas sobretudo na linguagem legislativa. Segundo ele o desconcerto doutrinário assumira tamanha proporção, que seria compreensível a desistência completa dos estudiosos do processo em adotar, de fato, tal nomenclatura e determinar sua conceituação. ${ }^{10}$

Para delinear melhor o conceito, fundamental entender, antes de tudo, sua origem histórica. A primeira referência ao tema nos remete ao direito romano. No sistema jurídico desenvolvido em Roma, o termo "praeiudicium" era utilizado de maneira abrangente, consistindo nos pronunciamentos judiciais ou processos que antecediam outros, lhes impondo certa influência. ${ }^{11}$

Esse era um conceito demasiadamente amplo. Em um mesmo processo, a prejudicialidade se configurava quando os pronunciamentos judiciais anteriores a sentença nela influíam, como é o caso de um juiz penal decidir incidentalmente uma questão civil para o melhor julgamento da matéria criminal. Em processos distintos, a prejudicialidade aparecia tanto

GRINOVER. Ada Pelegrini. Ação declaratória incidental. São Paulo: Revista dos Tribunais LTDA., 1972. p. 10.

${ }^{7}$ MENESTRINA, Francesco. La pregiudiciale nel processo civile. Milano: A. Giuffré, 1963.

${ }^{8}$ BARBOSA MOREIRA, José Carlos. Questões prejudiciais e coisa julgada. Rio de Janeiro: Borsoi, 1967.

${ }^{9}$ LEITE, Clarisse Frechiani Lara. Op. cit. p. XXI.

${ }^{10}$ BARBOSA MOREIRA, José Carlos. Questões prejudiciais e coisa julgada. Rio de Janeiro: Borsoi, 1967. p. 14.

${ }^{11}$ LEITE, Clarisse Frechiani Lara. Op. cit. p. 3. 
em forma de "precedente", ou seja, um modelo a ser adotado em casos semelhantes como de uma questão essencial ao julgamento de outra. ${ }^{12}$

Após certos percalços e imprecisões conceituais, mormente na Idade Média - em que o termo passou a ser relacionado com a ideia de prejuízo ou dano - a doutrina passou a adotar o entendimento de que a prejudicialidade seria uma sujeição de um juízo a outro. ${ }^{13} \mathrm{~A}$ ideia principal do instituto é que o julgamento de uma matéria seria um "antecedente lógico" para a apreciação de outra. ${ }^{14}$

Nas palavras de Barbosa Moreira a melhor doutrina compreende este fenômeno "como mero corolário da existência de relações de subordinação e dependência. As questões prévias são assim denominadas pelo fato da influência que suas soluções exercem sobre as outras questões”. ${ }^{15}$

Na mesma linha, Cândido Dinamarco precisamente assevera que:

"Há relação de prejudicialidade entre duas causas quando o julgamento de uma delas é apto a influir no de uma outra. A primeira diz-se prejudicial à segunda e esta, prejudicada". 16

Thereza Alvim também salienta:

“(...) se o magistrado puder resolver qualquer questão de mérito, ou não, sem examinar e solucionar outra, esta não poderá nem ser considerada questão prévia, quanto mais prejudicial, dado que não integrará o raciocínio lógico do juiz". ${ }^{17}$

A autora esclarece, ainda, que a antecedência lógica decorre de uma relação de dependência que existe entre a solução da questão prévia e da questão principal, tornando indispensável ao pronunciamento desta a anterior decisão sobre aquela. ${ }^{18}$

\footnotetext{
${ }^{12}$ Ibid. p. 4.

${ }^{13}$ Ibid. p.9.

${ }^{14}$ Ibid. p. 28.

${ }^{15}$ BARBOSA MOREIRA, José Carlos. Questões prejudiciais e coisa julgada. Rio de Janeiro: Borsoi, 1967. p. 11.

${ }^{16}$ DINAMARCO, Cândido Rangel. Instituições de direito processual civil. v. 2. $4^{\mathrm{a}}$ ed. São Paulo: Malheiros, 2004. p. 155.

${ }^{17}$ ALVIM, Thereza. Op. cit. p.13.

${ }^{18}$ Ibid. p. 14.
} 
Todavia, deve-se atear ao entendimento de que a ordem de dependência é muito mais lógica que cronológica. É que a princípio é irrelevante estabelecer uma ordem temporal. $\mathrm{Na}$ verdade, a questão prejudicial pode ser julgada simultaneamente com a questão prejudicada, inclusive, no mesmo pronunciamento judicial. De qualquer forma, o importante é que o raciocínio do juiz obedeça a um concatenado lógico julgando-se o prius (questão subordinante) e o postemus (questão subordinada). ${ }^{19}$

A importância de tal subordinação fica evidente quando se pensa na esquizofrênica hipótese de o operador no direito ignorar a lógica, antepondo a questão subordinada à questão subordinante. É o caso de o juízo apreciar a questão meritória apresentada em um recurso antes mesmo de analisar a tempestividade de sua interposição ou decidir sobre a constituição de um débito tributário antes mesmo de julgar a constitucionalidade da lei tributária. $^{20}$

\subsection{Questões prévias preliminares e questões prévias prejudiciais}

Segundo Barbosa Moreira, a partir da lógica de subordinação e dependência, surgiram duas correntes doutrinárias igualmente equivocadas. ${ }^{21}$

A primeira tratava como prejudicial toda a questão cuja solução precedesse logicamente de outra, de forma a ampliar desmedidamente o seu conceito. Além disso, não se preocupava com a distinção entre questões prejudiciais e preliminares, utilizando-se de tais adjetivos de forma completamente genérica para tratar de quaisquer questões prévias. ${ }^{22}$

19 BARBOSA MOREIRA, José Carlos. Questões prejudiciais e questões preliminares. In: BARBOSA MOREIRA, Jose Carlos. Direito Processual Civil (Ensaios e Pareceres). Rio de Janeiro: Borsoi, 1971. p. 76.

${ }^{20}$ Ibid. p. 76.

${ }^{21}$ BARBOSA MOREIRA, José Carlos. Questões prejudiciais e coisa julgada. Rio de Janeiro: Borsoi, 1967. p. 12.

${ }^{22}$ Ibid. p. 12. 
Verifica-se, portanto, insatisfatória essa linha de pensamento ao ignorar completamente a peculiaridade de cada um dos termos. Ora, como adverte Moreira, o próprio nomem iuris de preliminar não é tão expressivo quanto o de prejudicial. No primeiro, apenas está ínsita a ideia de antecedência, enquanto que no segundo, a de vinculação lógica e dependência. ${ }^{23}$

A segunda corrente, por outro lado, enfocou-se na diferenciação entre matérias constantes ao mérito e as demais matérias. Desta forma, restringiu o conceito de questões prejudiciais àquelas que diziam respeito ao mérito da causa e interviriam na solução final do litígio e conceituou as questões preliminares como as de caráter eminentemente processual - condições da ação. ${ }^{24}$ Esse, na verdade, é o entendimento consignado na prática processual, porém há grande discussão doutrinária a seu respeito.

Adroaldo Furtado ainda cita uma terceira corrente, cujos adeptos inseriram entre as questões prejudiciais (de mérito) e as questões preliminares (de rito) uma categoria denominada de "questões intermediárias", para que houvesse uma melhor correspondência com a classificação tríplice: processo, ação e mérito. Neste contexto, as chamadas questões intermediárias abrangeriam as condições da ação. ${ }^{25}$

Essa desordem conceitual não tem sede apenas doutrinária. O legislador foi completamente impreciso ao redigir o Código de Processo Civil de 1939, visto que nos artigos 877 e 878 do diploma processual, os adjetivos "prejudicial” e "preliminar" apareciam como sinônimos e no artigo 282 , o termo "questão prejudicial" abrangia qualquer questão prévia. ${ }^{26} \mathrm{Da}$ mesma forma, o código civil italiano também é desordenado, falando em

\footnotetext{
${ }^{23}$ Ibid. p. 31.

${ }^{24}$ Ibid. p. 12.

${ }^{25}$ FABRÍCIO. Adroaldo Furtado. A ação declaratória incidental. $3^{\mathrm{a}}$ ed. Rio de Janeiro: Forense, 1996. p. 45.

${ }^{26}$ BARBOSA MOREIRA, José Carlos. Questões prejudiciais e coisa julgada. Rio de Janeiro: Borsoi, 1967. p. 28.
} 
questioni pregiudiziali attinenti al processo, questioni pregiuziali e questioni preliminar di merito. ${ }^{27}$

Na doutrina Italiana, por sua vez, houve uma tentativa de elucidação da matéria. Com base nos ensinamentos de Francesco Menestrina, Gaetano Foschini consolidou o entendimento de que a distinção entre as questões prejudiciais e questões preliminares seria sua maior ou menor influência com a decisão final da lide. Neste sentido, apenas seria prejudicial a questão referente ao mérito que configurasse "antecedência lógica e imediata, capaz de integrar o silogismo judicial”, ${ }^{28}$

No Brasil, Barbosa Moreira se preocupou em apresentar uma distinção válida. Para ele a natureza das questões prévias, em si, não é fundamental a sua classificação como prejudicial ou preliminar. Pode haver prejudiciais que digam respeito a questões processuais, assim como, preliminares que se reportem ao mérito da causa. ${ }^{29} \mathrm{O}$ critério de distinção entre a questão prejudicial e a questão preliminar não deve partir da análise isolada das questões, mas da análise da "relação lógica de subordinação". 30

Segundo ele:

“(...) o critério de distinção entre as questões prejudiciais e preliminares há de ser buscado na diferenciação entre os dois tipos de influência. Cabendo a qualificação de "prejudiciais" as questões de cuja solução dependia do teor ou conteúdo da solução de outras, reservar-se-á a expressão "questões preliminares" para aquelas de cuja solução vá depender a de outras não no seu modo de ser, mas no seu próprio ser, isto é, para aquelas que, conforme o sentido em que sejam resolvidas, oponham ou, ao contrário, removam um impedimento a solução de outras, sem influírem, no segundo caso sobre o sentido em que estas outras hão de ser resolvidas." (grifos nossos) ${ }^{31}$

\footnotetext{
${ }^{27}$ LEITE, Clarisse Frechiani Lara. Op. cit. p. 40.

${ }^{28}$ FOCHINI, Gaetano. La pregiudizialitá nel processo penale. Milano: La stampa moderna, 1942. p. 46-47 apud. LEITE, Clarisse Frechiani Lara. Op. cit. p. 43.

${ }^{29}$ LEITE, Clarisse Frechiani Lara. Op. cit. p. 45.

30 BARBOSA MOREIRA, José Carlos. Questões prejudiciais e questões preliminares. In: BARBOSA MOREIRA, Jose Carlos. Direito Processual Civil (Ensaios e Pareceres). Rio de Janeiro: Borsoi. 1971.p. 81.

31 BARBOSA MOREIRA, José Carlos. Questões prejudiciais e coisa julgada. Rio de Janeiro: Borsoi, 1967. p. 30.
} 
Desta forma, conclui-se que as questões prévias condicionam a decisão principal a ser proferida no processo seja para impossibilitar tal decisão, seja para influenciar seu teor. ${ }^{32}$ Neste ponto, a distinção entre as questões prévias prejudiciais e questões prévias preliminares está estritamente relacionada ao tipo de influência exercido sobre a decisão subordinada. As questões prejudiciais são aquelas que influem no conteúdo da decisão prejudicada, de sorte que possam alterar seu teor de alguma forma, enquanto que as preliminares apenas têm o escopo de impedir ou tornar dispensável a decisão final, interferindo em sua existência. ${ }^{33}$

Na mesma linha de Barbosa Moreira, destacam-se diversos autores, como Adroaldo Furtado Fabrício.

Adroaldo Furtado afirma que a questão preliminar é aquela que "obsta a apreciação da subordinada, tornando-a desnecessária ou mesmo impossivel"34. Para ilustrar o conceito, traz o seguinte exemplo:

“(...) questão prévia relativa à legitimidade ad processum, se dirimida no sentido da ausência desse requisito, trunca aí mesmo o iter procedimental, impedindo o juiz de passar ao exame de outras questões, a respeito das quais fica pré-excluída qualquer apreciação", ${ }^{35}$.

Quanto à questão prejudicial, este autor a conceitua como aquela que "pode determinar o sentido em que esta (a subordinada) será resolvida"36. O exemplo trazido é:

“(...) chamado a responder como fiador, um réu opõe como defesa a nulidade ou inexistência da obrigação principal, a resolução judicial que acolher essa alegação, sem dispensar o órgão julgador de apreciar e decidir a questão principal condiciona, entretanto, o teor desta decisão, impondo, nesse exemplo, a improcedência da demanda".

Indo além, Adroaldo Furtado defende que se mesclados os dois critérios de classificação - o da natureza da questão prévia considerada em si mesma e o do grau de influência entre as questões prévias e a questão

\footnotetext{
${ }^{32}$ FABRÍCIO, Adroaldo Furtado. Op. cit. p. 45.

${ }^{33}$ LEITE, Clarisse Frechiani Lara. Op. cit., p. 45.

${ }^{34}$ FABRÍCIO, Adroaldo Furtado. Op. cit. p. 45 - 46.

${ }^{35}$ Ibid. p. 46.

${ }^{36}$ Ibid. p. 46

${ }^{37}$ Ibid. p. 46.
} 
principal - , pode-se falar em quatro espécies distintas de questões prévias, quais sejam: (i) prejudiciais de mérito, (ii) prejudiciais processuais, (iii) preliminares de mérito e (iv) preliminares processuais. ${ }^{38}$

Destarte, segundo o mestre Barbosa Moreira as questões prejudiciais são aquelas que influem no teor meritório de outras. Isso não significa necessariamente que a prejudicialidade vai se restringir ao mérito da causa. Realmente é no meritum causae que esse fenômeno ganha maior relevo, visto que a questão prejudicada versará sobre o pedido e será decidida pondo fim ao litígio, no entanto a prejudicialidade não se descaracteriza se referente às questões processuais. ${ }^{39}$

Após a devida explicitação do tema, importante voltar o estudo ao revogado Código de Processo Civil de 1939.

Como já exposto acima, alguns artigos do diploma processual tratavam o instituto de forma imprecisa. $\mathrm{O}$ artigo 282 assim dispunha:

“Art. 282 - Na sentença em que resolver questão prejudicial, o juiz decidirá igualmente do mérito da causa, salvo se esta decisão fôr incompatível com a proferida na questão prejudicial." ${ }^{40}$

De uma leitura atenta do dispositivo sob análise, conclui-se que, de fato, o legislador não fez um bom emprego do termo. Na primeira parte do artigo, nitidamente, sua verdadeira intenção era se referir as questões prévias latu senso, abrangendo tanto as prejudiciais quanto as preliminares. $\mathrm{Na}$ segunda parte do artigo, por outro lado, fica ainda mais latente o equívoco legislativo, visto que jamais a questão prejudicial seria incompatível com a

\footnotetext{
${ }^{38}$ Ibid. p. 47.

39 BARBOSA MOREIRA, José Carlos. Questões prejudiciais e questões preliminares. In: BARbOSA MOREIRA, Jose Carlos. Direito Processual Civil (Ensaios e Pareceres). Rio de Janeiro: Borsoi. 1971. p. 87.

${ }^{40}$ BRASIL. Decreto-Lei n. 1608, de 18 de setembro de 1939. Código de Processo Civil. Rio de Janeiro. 18 set. 1939. Disponível em: <http://www.planalto.gov.br/ccivil_03/decreto-lei/19371946/Del1608.htm> Acesso em: 10 mar. 2019.
} 
questão principal, mas tão-somente influenciaria no seu conteúdo. ${ }^{41}$ Desta forma, Barbosa Moreira propõe a seguinte leitura do artigo:

"Na sentença, em que resolver questão prévia, que condicione o julgamento do mérito, o juiz decidirá igualmente deste, salvo se se tratar de questão preliminar e a solução dela preexcluir o conhecimento da questão (principal) de mérito." ${ }^{42}$

Da mesma forma, nos artigos 877 e 888, o legislador utilizou-se dos termos "questões prejudiciais" e "questões preliminares" de forma genérica, sem a devida cautela com suas peculiaridades, senão vejamos:

“Art. 877. Qualquer questão preliminar ou prejudicial, suscitada no julgamento, será julgada antes do mérito, deste não se conhecendo se incompatível com a decisão da preliminar ou da prejudicial.

Art. 878. Rejeitada a preliminar ou a prejudicial, ou se com elas não fôr incompatível a apreciação do mérito, seguir-se-á, a discussão e julgamento da matéria principal, sobre esta devendo pronunciar-se os juízes vencidos na preliminar" 43

\subsection{Fenômeno da prejudicialidade: prejudicialidade lógica e jurídica}

Neste ponto, é essencial tratar dos aspectos jurídicos do fenômeno da prejudicialidade, visto que o enfoque puramente lógico ampliaria sobremaneira o conceito do termo. Como sabiamente redigiu Barbosa Moreira em "Questões prejudiciais e coisa julgada":

"Desde os primeiros esforços de reconstrução sistemática, nos tempos modernos, do conceito de questão prejudicial, sentiu-se a necessidade de distinguir, no tratamento da matéria, o aspecto puramente lógico e aquele que seria lícito identificar de maneira específica, uma relevância propriamente jurídica. Já havia chegado, embora sem desenvolver-lhe todas as potencialidades, a percepção de que a essência da prejudicialidade deveria ser procurada na relação de dependência entre duas questões, ou melhor, na influência a solução de uma exerce sobre a de outra. Mas também se percebeu que, se se quisesse resolver o problema nessa perspectiva estritamente lógica, a significação do conceito acabaria por perder

41 BARBOSA MOREIRA, José Carlos. Questões prejudiciais e questões preliminares. In: BARBOSA MOREIRA, Jose Carlos. Direito Processual Civil (Ensaios e Pareceres). Rio de Janeiro: Borsoi. 1971.p. 90.

42 Ibid. p. 90.

${ }^{43}$ BRASIL. Decreto-Lei n. 1608, de 18 de setembro de 1939. Código de Processo Civil. Rio de Janeiro. 18 set. 1939. Disponível em: <http://www.planalto.gov.br/ccivil_03/decreto-lei/19371946/Del1608.htm> Acesso em: 10 mar. 2019. 
muito de seu interesse jurídico, na mesma medida em que se alargariam os limites de sua extensão."

Para melhor compreensão da abordagem jurídica do fenômeno da prejudicialidade, deve-se voltar os olhos ao processo. Dispõe Adroaldo Furtado que:

“(...) processo é caminho que se percorre rumo à sentença de mérito, por força da
qual se atribui ou negue a alguém determinado bem da vida e assim se alcance, em
maior ou menor grau de perfeição, o duplo escopo de realização do direito objetivo
(atuação da vontade concreta da lei) e de composição do conflito de interesses
(pacificação pela supressão do litígio". ${ }^{45}$

Evidentemente a prolação da sentença de mérito em um processo depende do exame apurado do juiz acerca de um conjunto de questões completamente distintas entre si, que podem condicionar seu pronunciamento. Considerar todas estas questões que surgem no decurso do pleito como prejudiciais seria distorcer o conceito. É o caso de se chegar à conclusão descabida de que a decisão do juiz, em acolher como verdadeiros ou falsos os fatos narrados em um depoimento testemunhal, seria prejudicial, apenas pelo fato de interferir de alguma maneira do julgamento final da lide. É exatamente em virtude de distorções como esta, que os processualistas se preocuparam em estabelecer critérios jurídicos mais específicos e restritivos. ${ }^{46}$

Deste esforço em aperfeiçoar o conceito, surgiram diversas correntes. Alguns autores, influenciados pelos efeitos processuais do instituto em seus ordenamentos jurídicos, entenderam que a questão prejudicial seria aquela cuja decisão competia a outro juízo. Desta forma, a prejudicialidade tomaria forma quando uma questão fosse remetida a outro órgão julgador, ficando suspenso o processo principal. ${ }^{47}$ Segundo Thereza Alvim, a nota distintiva de um instituto nunca poderia ser encontrada puramente em seus efeitos, mas

\footnotetext{
${ }^{44}$ BARBOSA MOREIRA, José Carlos. Questões prejudiciais e coisa julgada. Rio de Janeiro: Borsoi, 1967. p. 43.

${ }^{45}$ FABRÍCIO. Adroaldo Furtado. Op. cit. p. 42 e 43.

${ }^{46}$ BARBOSA MOREIRA, José Carlos. Questões prejudiciais e coisa julgada. Rio de Janeiro: Borsoi, 1967. p. 43-44.

${ }^{47}$ LEITE, Clarisse Frechiani Lara. Op. cit., p. 60.
} 
sim em sua estrutura, principalmente neste caso, em que a suspensão do processo dependeria do direito positivado em cada ordenamento jurídico. ${ }^{48}$

Completamente distinto era o entendimento da corrente adotada pelos processualistas penais. Estes sustentavam que a questão prejudicial deveria se referir a matéria diversa daquela em análise no processo principal, de sorte que seu traço primordial seria a heterogeneidade. Essa corrente se ramificava em outras duas, aqueles que entendiam que as questões prejudiciais deveriam ser de natureza civil e outros que defendiam que poderiam ser de qualquer natureza não-penal. ${ }^{49}$

Além destas, há duas linhas de pensamento que merecem destaque. Ambas têm como traço comum a ideia, já sustentada neste trabalho, de que a questão prejudicial seria aquela que influiria o próprio conteúdo da decisão principal como um antecedente lógico. A primeira corrente sustentava que o que caracterizaria a prejudicialidade seria a natureza de subsunção do juízo prejudicial e segunda defendia que o que, de fato, a caracterizaria seria a aptidão da questão prejudicial em constituir objeto de um processo autônomo. ${ }^{50}$

Francesco Menestrina, defensor da primeira corrente, sustentava que o elemento jurídico da prejudicialidade seria "a natureza de subsunção do juízo prejudicial”. Diz ele que a atividade realizada pelo magistrado é de subsunção, sendo o juízo final simplesmente a aplicação de uma norma abstrata a um caso concreto. Desta forma, considerando que "um prejuizo não é mais do que um juízo não final”, a questão prejudicial seria aquela que abrangesse um juízo lógico igual ao contido na decisão final prejudicada. ${ }^{51}$

A segunda corrente, por outro lado, fora inicialmente defendida por Böhmer, que conceituava as questões prejudiciais como controvérsias jurídicas independentes. A maioria dos adeptos desta corrente, muito embora

\footnotetext{
${ }^{48}$ ALVIM, Thereza. op. cit. p. 20.

${ }^{49}$ LEITE, Clarisse Frechiani Lara. Op. cit., p. 61.

${ }^{50}$ Ibid. p. 62.

${ }^{51}$ MENESTRINA, Francesco. Op cit. p. 103 apud. LEITE, Clarisse Frechiani Lara. Op. cit., p. 62.
} 
admitissem o elemento jurídico da subsunção do juízo prejudicial, acreditavam que o indispensável à caracterização da prejudicialidade seria na verdade: a aptidão da questão prejudicial em constituir o objeto de um processo autônomo ou juízo autônomo. ${ }^{52}$

Esta corrente excluía do âmbito da prejudicialidade as questões relativas a fatos jurídicos e os aspectos meramente processais, como valor da causa, competência e valoração da prova. Isso porque estas questões podem ser observadas na atividade de subsunção, mas não podem constituir objeto de um processo autônomo. ${ }^{53}$

Outros defensores da autonomia da questão prejudicial foram Chiovenda, Gaetano Foschini e outros autores italianos como Comoglio, Ferri e Taruffo. ${ }^{54}$

Gaetano Foschini apontava para a insuficiência da teoria da subsunção, por adotar critérios meramente teóricos e lógicos, sem voltar a devida atenção para a prática processual. $\mathrm{O}$ autor se filiou, portanto, a corrente da autonomia, defendendo que a questão prejudicial "seria apenas aquela que poderia ser decidida em outro processo como questão principal." 55

Ressalva-se, contudo, que os critérios adotados pelo referido autor italiano para defender seu posicionamento foram distintos dos demais estudiosos. Segundo ele, a prejudicialidade assim como o cúmulo do processo seriam espécies de conexão. Isto significa que, as duas seriam formas de vincular a resolução de uma controvérsia a outra controvérsia, mas seus efeitos seriam diferentes. Na conexão, haveria a união de ambas as controvérsias para posterior julgamento por um único órgão jurisdicional, enquanto que na prejudicialidade, a união das controvérsias seria impossível.

\footnotetext{
${ }^{52}$ LEITE, Clarisse Frechiani Lara. p. 69.

${ }^{53}$ Ibid. p. 70.

${ }^{54}$ Ibid. p. 70

${ }^{55}$ FOCHINI, Gaetano. Op cit. p. 109 apud. LEITE, Clarisse Frechiani Lara. Op. cit., p. 65
} 
Desta forma, ficaria evidente a capacidade da questão prejudicial em figurar como objeto principal de um processo autônomo. ${ }^{56}$

No Brasil, Scarance Fernandes e Adroaldo Furtado aderiram a corrente da autonomia, mas, sem, contudo, ignorar a subsunção necessária a configuração do fenômeno. Tais autores conceituavam a questão prejudicial como aquela que, não apenas traduzisse um juízo de subsunção do fato à norma, como também, tivesse a aptidão de constituir objeto de juízo autônomo. ${ }^{57}$

Neste ponto, urge salientar que esta autonomia não significava necessariamente que a questão fosse decidida em separado. Segundo Adroaldo Furtado: "deve-se entender que basta a autonomia abstrata da questão, a saber, a simples possibilidade de ser ela julgada principaliter em outro processo". Afirma o autor que o cerne do estudo da prejudicialidade é a extensão objetiva da coisa julgada, por isso as questões ditas como prejudiciais são inevitavelmente aquelas que possam formar coisa julgada material. $^{58}$

Outra estudiosa que parece seguir a corrente da autonomia é Ada Pelegrini Grinover, quando afirma que

\begin{abstract}
"A moderna doutrina processual reservou a denominação "questão prejudicial" para as questões relativas a outros estados ou relações jurídicas, que não dizem respeito à relação jurídica controvertida, mas que, podendo embora ser por si objeto de um processo independente, apresentam-se naquele determinado processo como ponto duvidoso na discussão da questão principal." ${ }^{, 59}$

Barbosa Moreira, o expoente do fenômeno da prejudicialidade no Brasil, é adepto da corrente da subsunção. Segundo ele, o campo da prejudicialidade em sentido jurídico se limita aos casos em que a lógica de
\end{abstract}

\footnotetext{
${ }^{56}$ LEITE, Clarisse Frechiani Lara. Op. cit., p. 71-72.

${ }^{57}$ Ibid. p. 73.

${ }^{58}$ FABRÍCIO, Adroaldo Furtado. Op. cit. p. 50.

${ }^{59}$ GRINOVER, Ada Pelegrini. Op. cit. p. 10.
} 
aplicação da norma ao fato for idêntica àquela que dá nascimento à sentença definitiva. ${ }^{60}$

O autor criticou de forma contumaz a corrente da autonomia, afirmando que esta é completamente inútil em âmbito prático. Para ele:

“a mera possibilidade abstrata de que certa questão constitua objeto de juízo autônomo, por si só, tampouco produz necessariamente repercussão prática na disciplina procedimental. No direito brasileiro e alhures, em numerosos casos, o órgão judicial aprecia e resolve sem qualquer especial formalidade, questão que, em tese, poderia ser apreciada e decidida autonomamente; aprecia-a e resolve-a, em regra, junto com a própria questão subordinada.", 61

Em contrapartida, aqueles autonomistas que realmente exigem que a questão prejudicial seja julgada em separado de forma autônoma, com a eventual suspensão do processo principal, acabam por retroagir a concepção meramente procedimental ultrapassada. ${ }^{62}$

Outra questão trazida à baila pelo doutrinador fluminense é que o critério da autonomia acaba por confundir os termos "questão" e "causa" prejudicial. Apenas constituiria questão prejudicial aquela que tivesse aptidão para ser objeto de uma causa prejudicial. Segundo Barbosa:

"ou a causa surge efetivamente, e nesse caso já se ultrapassou o plano da mera "questão" ou não surge, ficando aquela aptidão em estado puramente potencial, e nesse caso não se vê a adoção de critério proposto se avantaje, do ponto de vista de relevância prática”. ${ }^{63}$

Barbosa Moreira termina sua explanação aduzindo que o critério da autonomia compromete sobremaneira a visão unitária da prejudicialidade, contrariando a possibilidade de a natureza da questão prejudicial ser puramente processual. ${ }^{64}$

\footnotetext{
${ }^{60}$ BARBOSA MOREIRA, José Carlos. Questões prejudiciais e coisa julgada. Rio de Janeiro: Borsoi, 1967. p. 65.

${ }^{61}$ Ibid. p. 47.

${ }^{62}$ LEITE, Clarisse Frechiani Lara. Op. cit., p. 66.

${ }^{63}$ BARBOSA MOREIRA, José Carlos. Questões prejudiciais e coisa julgada. Rio de Janeiro: Borsoi, 1967. p. 49.

${ }^{64}$ Ibid. p. 49.
} 
Ultrapassada a análise perfunctória do tema em sede doutrinária, neste projeto adota-se como questões prejudiciais aquelas relativas ao direito material, que são apenas conhecidas incidentalmente no processo como um antecedente lógico para que o juiz decida a questão principal. Como exemplo pode-se citar o reconhecimento da paternidade em uma ação de alimentos e a inconstitucionalidade de uma norma em uma ação tributária.

\subsection{Classificação das questões prejudiciais: ponto, questão e causa}

Muito embora a doutrina não tenha se debruçado muito sobre o fenômeno da prejudicialidade, são diversas as classificações existentes. Dentre elas: prejudicial (a.1.) em sentido amplo e (a.2.) em sentido estrito; (b.1) imediata e (b.2) mediata; (c.1.) total e (c.2) parcial; (d.1.) própria e (d.2) imprópria; (e.1.) de rito e (e.2.) de mérito; (f.1) obrigatória e (f.2) facultativa; (g.1) homogênea e (g.2) heterogênea; (h.1) internas e (h.2) externas; e (i.1) ponto, (i.2) questão e (i.3) causa. ${ }^{65}$

Destaca-se, neste projeto, a última classificação, que tem um apelo processual mais acentuado. A figura prejudicial pode se apresentar no processo como um ponto, uma questão ou uma causa.

O ponto é a manifestação mais singela da prejudicialidade. Segundo Talamini e Wambier, ponto, latu senso, "é uma matéria que se encontra no processo e que deve ser objeto da atividade cognitiva (do juiz)" .66 Para a presente classificação, pode-se dizer que ponto constitui uma premissa, sob

\footnotetext{
${ }^{65}$ LEITE, Clarisse Frechiani Lara. Op. cit., p. 93. Adroaldo Furtado e Barbosa Moreira também se referem as prejudiciais heterogêneas e homogêneas e as obrigatórias e facultativas. FABRÍCIO. Furtado. Adroaldo. Op. cit. p. 54-55; BARBOSA MOREIRA, José Carlos. Questões prejudiciais e coisa julgada. Rio de Janeiro: Borsoi, 1967. p. 56-58.

${ }^{66}$ TALAMINI, Eduardo; WAMBIER, Luiz Rodrigues. Curso Avançado de Processo civil: teoria geral do processo e processo de conhecimento. v. 1. 13ª ed. São Paulo: Revista dos Tribunais, 2013. p. 412.
} 
a qual não foi suscitada qualquer dúvida tanto pela parte adversa quanto pelo juízo. ${ }^{67}$

A questão prejudicial - que a forma mais usual da prejudicialidade pressupõe uma dúvida sobre um ponto no curso do pleito judicial, que será apreciada pelo magistrado. ${ }^{68}$ Logo, a questão nada mais é que "um ponto controverso envolvendo os fatos e as regras jurídicas debatidas pelas partes. "69

Considerando que a questão é a controvérsia no plano lógico apreciada incidenter tantum no processo, a causa prejudicial seria aquela presente no campo imperativo, que necessita de uma decisão principaliter $^{70}$ Segundo Thereza Alvim a causa prejudicial surge como lide no mesmo processo através da declaração incidental ou em outro processo, de forma autônoma. Desta forma, a prejudicialidade, se controversa, figura-se em questão prejudicial, mas pode vir a tornar-se uma lide (causa prejudicial). ${ }^{71}$

\footnotetext{
${ }^{67}$ LEITE, Clarisse Frechiani Lara. Op. cit., p. 100.

${ }^{68}$ LETE, Clarisse Frechiani Lara. Op. cit., p. 111.

${ }^{69}$ THEODORO JÚNIOR, Humberto. Curso de Direito Processual Civil: Teoria geral do direito processual civil, processo de conhecimento e procedimento comum. v. I. 59 $9^{\mathrm{a}}$ ed. Rio de Janeiro: Forense, 2018. p. 1156.

${ }^{70}$ LEITE, Clarisse Frechiani Lara. Op. cit., p. 113.

${ }^{71}$ ALVIM, Thereza. op. cit. p. 27-28.
} 


\section{CAPÍTULO 2. COISA JULGADA}

Após essa detida análise do fenômeno da prejudicialidade, passa-se ao exame da coisa julgada. De início, será destacado sua proeminente função de proporcionar a segurança jurídica nas relações processuais. Posteriormente, o trabalho se enfocará no conceito de coisa julgada, a tradicional distinção entre coisa julgada material e formal, sua eficácia negativa e positiva e os seus limites objetivos, subjetivos e temporais.

\subsection{Coisa julgada como garantia constitucional}

A coisa julgada transcende os limites do direito processual e material, para ser reconhecida como uma garantia constitucional inscrita em nossa Carta Magna. ${ }^{72} \mathrm{~A}$ manifesta intenção do constituinte ao estabelecer que " $a$ lei não prejudicará o direito adquirido, o ato jurídico perfeito e a coisa julgada" (art. 5, inc. XXXVI) ${ }^{73}$ foi de assegurar a imunidade destas três situações, em nome de um dos mais basilares princípios democráticos, que é o da segurança jurídica. ${ }^{74}$

Segundo Canotilho, a segurança jurídica dos atos processuais, além de fundamental ao Estado de direito, se desenvolve em torno de dois conceitos: (i) estabilidade das decisões dos poderes públicos, que uma vez proferidas não devem ser contingentemente modificadas; e (ii) previsibilidade, que reconduz com a certeza e a "calculabilidade" por parte dos cidadãos. ${ }^{75}$

\footnotetext{
72 SILVA, Ovídio A. Baptista da; GOMES, Fábio Luiz. Teoria geral do Processo Civil. $3^{\mathrm{a}}$ ed. São Paulo: Revista dos Tribunais, 2002. p. 322. Neste mesmo sentido Rel. Min, Celso de Mello (STF, $1^{\text {a }}$ Turma, AgRg no RE 592.912/RS, j. 03.04.2012, Dje 22.11.2012).

73 BRASIL. Constituição da República Federativa do Brasil de 1988. Brasília. 05 out. 1988. Disponível em: <http://www.planalto.gov.br/ccivil_03/constituicao/constituicao.htm>. Acesso em: 02 abr.2019.

${ }^{74}$ DINAMARCO, Cândido Rangel. Instituições de direito processual civil. v. $37^{\mathrm{a}}$ ed. São Paulo: Malheiros, 2017. p. 356.

${ }^{75}$ CANOTILHO, José Joaquim Gomes. Direito Constitucional. $7^{\mathrm{a}}$ ed. Coimbra: Almedina, 2003. p. 264.
} 
A segurança jurídica é caracterizada quando se pensa na coisa julgada como um produto do processo. Ela é criada por meio de um procedimento, ou seja, uma sequência ordenada de atos processuais, com respeito ao contraditório e ao devido processo legal (artigo $5^{\circ}$, LIV e LV da Constituição Federal $)^{76}$, que resulta em uma decisão de mérito que vem a se tornar irrecorrível ${ }^{77}$ e a partir de então, estável e indiscutível.

A estabilidade que atinge essa decisão de mérito irrecorrível se alicerça em três fundamentos: um jurídico, um político e outro social. O escopo jurídico reclama a definitiva tutela jurisdicional, de forma a prestigiar o resultado do processo. $O$ escopo político traz à tona a afirmação da autoridade do Estado como detentor do poder jurisdicional. O escopo social oferece a pacificação das controvérsias, viabilizando a vida em sociedade ${ }^{78}$, visto que "a insegurança é um estado perverso prejudicial aos negócios, ao crédito, às relações familiares e, por isso, à felicidade pessoal dos indivíduos ou grupos." 79

Portanto, como vaticina Dinamarco:

"Vista com a amplitude própria do direito constitucional, ela (coisa julgada) é uma garantia oferecida ao vencedor, para que a segurança obtida mediante a decisão de mérito passada em julgado fique imune a novos questionamentos, seja pelo legislador, pelo administrador, seja pelo vencido ou pelos próprios juízes." ${ }^{, 0}$

\subsection{Reflexões doutrinárias sobre o conceito de coisa julgada e sua repercussão no direito positivado}

A coisa julgada é uma matéria muito polêmica, não à toa é frequente alvo de discussões entre os processualistas. A evolução doutrinária acerca do

\footnotetext{
${ }^{76}$ BRASIL. Constituição da República Federativa do Brasil de 1988. Brasília. 05 out. 1988. Disponível em: 〈http://www.planalto.gov.br/ccivil_03/constituicao/constituicao.htm〉. Acesso em: 02 abr.2019.

${ }^{77}$ DINAMARCO, Cândido Rangel. Instituições de direito processual civil. v. $37^{\mathrm{a}}$ ed. São Paulo: Malheiros, 2017. p. 357.

${ }^{78}$ CRAMER, Ronaldo. Ação rescisória por violação da norma jurídica. São Paulo: 2010.191 p. Dissertação de Mestrado em Direito na Pontifícia Universidade Católica de São Paulo. p. 35.

${ }^{79}$ DINAMARCO, Cândido Rangel. Instituições de direito processual civil. v. $37^{\mathrm{a}}$ ed. São Paulo: Malheiros, 2017. p. 356

${ }^{80}$ Ibid. p. 357.
} 
tema fora tortuosa, mormente no que diz respeito à sua natureza e, consequente, conceituação.

Antigamente, pensava-se na coisa julgada como um dos efeitos da sentença. Algum tempo depois, surgiu uma corrente na Alemanha, defendida por Hellwig e Rosemberg e no direito pátrio, por Pontes de Miranda e Celso Neves, que via a coisa julgada como um efeito declaratório da sentença insuscetível de recurso, ${ }^{81}$ de forma que a imutabilidade e a indiscutibilidade, próprios da coisa julgada, alcançavam apenas o conteúdo declaratório da decisão judicial. ${ }^{82}$

Assim, o termo "coisa julgada" (Rechtskraft) poderia ser facilmente substituído por "eficácia da declaração" (Feststellungswirkung). ${ }^{83}$

Neste sentido, afirma Celso Neves:

"Coisa julgada é o efeito da sentença definitiva sobre o mérito da causa que, pondo termo final à controvérsia, faz imutável e vinculativo, para as partes e para os órgãos jurisdicionais, o conteúdo declaratório da decisão final.”. ${ }^{84}$ (grifos nossos)

Liebman problematiza as consequências práticas de tal teoria. Diz o italiano: "indicando na coisa julgada um efeito da sentença e distinguindolhe o eventual efeito constitutivo ou condenatório, exclui ele da autoridade do julgado estes últimos efeitos e os torna independentes desta". ${ }^{85}$

Humberto Theodoro Junior também critica o referido entendimento, ao afirmar que a partir do momento em que passa em julgado uma sentença, a autoridade da coisa julgada incidirá para todos os efeitos da decisão, não só o declaratório, como também o constitutivo e o condenatório. Prossegue ele dizendo que é impensável que um provimento constitutivo (como a anulação

\footnotetext{
${ }^{81}$ THEODORO JÚNIOR, Humberto. Op. cit. p. 1139.

${ }^{82}$ Ibid. p. 1139.

${ }^{83}$ LIEBMAN, Enrico Tullio. Efícácia e autoridade da sentença e outros escritos sobre a coisa julgada (com aditamentos relativos ao direito brasileiro). $2^{\mathrm{a}}$ ed. Rio de Janeiro: Forense, 1981. p. 18.

${ }^{84}$ NEVES, Celso. Coisa Julgada Civil. São Paulo: Revista dos Tribunais. 1971. p. 443.

${ }^{85}$ LIEBMAN, Enrico Tullio. Op. cit. p. 20.
} 
de um contrato) ou um provimento condenatório (como a condenação a cumprir uma obrigação) sejam suscetíveis de modificação após o trânsito em julgado. ${ }^{86}$

Contrário à corrente alemã, o mestre italiano Liebman apontava que a coisa julgada não seria, por si só, um efeito da decisão de mérito, mas sim uma qualidade que incidiria sobre os efeitos desta (não apenas o declaratório). Em suas palavras, a coisa julgada constituiria essencialmente em "uma qualidade, mais intensa e mais profunda, que reveste o ato também em seu conteúdo e torna assim imutáveis, além do ato em sua existência formal, os efeitos, quaisquer que sejam, do próprio ato. ” 87

Ora, a decisão judicial meritória sempre lança seus efeitos naturais para fora do processo. Neste contexto, a coisa julgada seria apenas uma "capa protetora", que protege os efeitos da decisão nos casos que, por exemplo, o legislador modifica de alguma forma as relações jurídica-materiais entre os sujeitos processuais; ou o vencido desconsidera o julgado, portando-se de forma contrária ao definido na sentença. ${ }^{88}$

De fato, uma das maiores contribuições de Liebman para a temática da coisa julgada foi exatamente o distanciamento entre a eficácia da decisão e a autoridade da coisa julgada. Diz o mestre italiano que:

“(...) a autoridade da coisa julgada não é efeito da sentença, como postula a doutrina unânime, mas, sim, modo de manifestar-se e produzir-se dos efeitos da própria sentença, algo que a esses efeitos se ajunta para qualifica-los e reforça-los em sentido bem determinado". 89

Para melhor compreensão desta distinção em termos é importante rememorar que os efeitos de uma decisão podem ser produzidos a despeito

\footnotetext{
86 THEODORO JÚNIOR, Humberto. Op. cit. p. 1139.

${ }^{87}$ LIEBMAN, Enrico Tullio. Op. cit. p. 54.

${ }^{88}$ DINAMARCO, Cândido Rangel. Instituições de direito processual civil. v. 3. $7^{\text {a }}$ ed. São Paulo: Malheiros, 2017. p. 365.

${ }^{89}$ LIEBMAN, Enrico Tullio. Op. cit. p. 46.
} 
do trânsito em julgado, como é o caso de uma sentença exequível provisoriamente, que produz seus efeitos sem a cobertura da coisa julgada. ${ }^{90}$

Adepto a essa percepção, Dinamarco esclarece:

“(...) em princípio é mais prudente condicionar a eficácia da sentença à sua imutabilidade mas essa correspondência não é invariavelmente necessária nem constante porque há também razões para liberar a primeira, em alguns casos, antes que ocorra a segunda (execução provisória ou cumprimento provisório da sentença)."

Diante do exposto, para Liebman uma coisa é o reconhecimento dos efeitos da sentença, outra, completamente diversa, é a verificação da imutabilidade ou não destes efeitos ao longo do tempo. ${ }^{92}$

Em uma tentativa de mesclar as duas correntes anteriores, Ovídio Baptista e Fabio Luiz Gomes adotaram o entendimento de que a coisa julgada seria "a qualidade que torna indiscutível o efeito declaratório da sentença, uma vez exauridos os recursos com que os interessados poderiam atacá-la.". Desta forma, o autor foi fiel a doutrina clássica, limitando a res iudicata ao efeito declaratório da decisão, mas inovou, utilizando-se dos ensinamentos de Liebman, apenas para considerar a coisa julgada uma qualidade, não de todos os efeitos da decisão como pretendia o italiano, mas do efeito declaratório. ${ }^{93}$

Há quem vá além, não somente negando a qualidade da coisa julgada como efeito da sentença, mas desvinculando-a do plano de eficácia do julgado. ${ }^{94}$ Segundo Barbosa Moreira, a coisa julgada não se manifestaria nos efeitos da decisão, mas sim em seu conteúdo, como norma jurídica concreta. $^{95}$

\footnotetext{
90 THEODORO JÚNIOR, Humberto. Op. cit. p. 1139.

${ }^{91}$ DINAMARCO, Cândido Rangel. Instituições de direito processual civil. v. 3. $7^{\mathrm{a}}$ ed. São Paulo: Malheiros, 2017. p. 355.

92 BUENO, Cassio Scarpinella. Curso sistematizado de direito processual civil: Procedimento comum ordinário e sumário. v. 2. $7^{\text {a }}$ ed. São Paulo: Saraiva, 2014. p. 374.

${ }^{93}$ SILVA, Ovídio A. Baptista da; GOMES, Fábio Luiz. Op. cit. p. 325.

94 THEODORO JÚNIOR, Humberto. Op. cit. p. 1139 -1140.

95 BARBOSA MOREIRA, José Carlos. Ainda e sempre coisa julgada. In: BARBOSA MOREIRA, Jose Carlos. Direito Processual Civil (Ensaios e Pareceres). Rio de Janeiro: Borsoi. 1971.p. 139.
} 
O processualista assevera, entretanto, que a imutabilidade do conteúdo da sentença não significa a imutabilidade da situação jurídica concreta levada à análise pelo judiciário. $\mathrm{O}$ fato de o titular do direito subjetivo ter sua prestação, de algum modo, satisfeita, recebendo-a ou resolvendo abrir mão dela, não importa na modificação dos efeitos da coisa julgada. O que acontece, na verdade, é o surgimento de fatos jurídicos estranhos àqueles acobertados pelo trânsito em julgado. Assim, diz Barbosa Moreira, "a norma sentencial permanece imutável, enquanto norma jurídica concreta referida a uma determinada situação". ${ }^{96}$

Apresentado um recorte da doutrina, serão feitos a seguir comentários acerca da temática em âmbito legislativo nacional.

O conceito de coisa julgada na legislação brasileira variou muito durante o tempo. Um dos primeiros dispositivos legais a tratar sobre o assunto foi o artigo $6^{\circ}, \S 3^{\circ}$ da Lei de Introdução às Normas do Direito Brasileiro, que ainda prevê que "chama-se coisa julgada ou caso julgado a decisão de que já não caiba recurso" ${ }^{97}$. Assim, seu conceito restringe a coisa julgada a uma decisão dotada de uma característica especial: sentença irrecorrível. ${ }^{98}$ É evidente, contudo, que essa definição é insuficiente, pois não se pode confundir coisa julgada com a própria sentença. ${ }^{99}$ Como salienta Barbosa Moreira, "nem o termo "sentença" equivale a "res", nem "irrecorrivel" a "iudicata",. 100

Posteriormente, o Código de Processo Civil de 1973 conceituava, em seu artigo 467, a coisa julgada como "a eficácia, que torna imutável e

\footnotetext{
${ }^{96}$ Ibid. p. 143.

97 BRASIL. Decreto-Lei n. 4.657, de 04 de setembro de 1942. Lei de Introdução às Normas do Direito Brasileiro. Rio de Janeiro, 04 set. 1942. Disponível em: <http://www.planalto.gov.br/ccivil_03/Decreto-Lei/Del4657compilado.htm> Acesso em: 25 abr. 2019.

${ }^{98}$ BARBOSA MOREIRA, José Carlos. Ainda e sempre coisa julgada. In: BARBOSA MOREIRA, Jose Carlos. Direito Processual Civil (Ensaios e Pareceres). Rio de Janeiro: Borsoi. 1971. p. 134. ${ }^{99}$ CABRAL, Antonio do Passo. Coisa julgada. In: WAMBIER, Teresa Arruda Alvim et al (coord.). Breves comentários ao Novo Código de Processo Civil. São Paulo: Revista dos Tribunais, 2015. p. $1280 / 1281$.

${ }^{100}$ BARBOSA MOREIRA, José Carlos. Ainda e sempre coisa julgada. In: BARBOSA MOREIRA, Jose Carlos. Direito Processual Civil (Ensaios e Pareceres). Rio de Janeiro: Borsoi. 1971. p. 134.
} 
indiscutível a sentença, não mais sujeita a recurso ordinário ou extraordinário." 101

Essa concepção foi superada pelo Código de Processo Civil de 2015, que adotou explicitamente a corrente de Liebman, ao definir a coisa julgada como "a autoridade que torna imutável e indiscutivel a decisão de mérito não mais sujeita a recurso". ${ }^{102}$

Para os seguidores da concepção liebmiana, a substituição do termo “eficácia” por "autoridade" no novo diploma processual civil é um dos maiores progressos da ciência processual. ${ }^{103}$

Entretanto, há quem não considere pertinente tal alteração legislativa. Teresa Arruda Alvim Wambier, Fredie Didier, Eduardo Talamini e Antônio Passo Cabral entendem que a teoria de Liebman acabou por "demonizar" o uso dos termos "efeito" ou "eficácia" da coisa julgada. Segundo os proeminentes autores o fato de a coisa julgada não ser exatamente um efeito da decisão, não significa que ela não possa ser o efeito de algum fenômeno no sistema jurídico. Prosseguem eles dizendo que a coisa julgada, como uma espécie das várias estabilidades processuais, poderia continuar sendo conceituada como uma "eficácia", tal qual previa o revogado Código de Processo Civil. ${ }^{104}$

Outra alteração interessante é a supressão de "recurso ordinário ou extraordinário". Festejada tal modificação legislativa, visto que remontava sistemas estrangeiros, nos quais, de fato, existem diferenças entre recursos

${ }^{101}$ BRASIL. Lei n. 5.869, de 11 de janeiro de 1973. Código de Processo Civil. Brasília. 11 jan. 1973. Disponível em: < http://www.planalto.gov.br/ccivil_03/leis/15869impressao.htm>. Acesso em 15 abr. 2019.

${ }^{102}$ BRASIL. Lei n. 13.105, de 16 de março de 2015. Código de Processo Civil. Brasília, 16 de mar. 2015. Disponível em: <http://www.planalto.gov.br/ccivil_03/_ato20152018/2015/lei/113105.htm>. Acesso em 15 de abr. 2019.

${ }^{103}$ DINAMARCO. Cândido Rangel. Instituições de direto processual civil. v. 3. $7^{\mathrm{a}}$ ed. São Paulo: Malheiros, 2017. p. 366.

${ }^{104}$ CABRAL, Antonio do Passo. Coisa julgada. In: WAMBIER, Teresa Arruda Alvim et al (coord.). Breves comentários ao Novo Código de Processo Civil. São Paulo: Revista dos Tribunais, 2015.p. 1280/1281. A estabilidade processual é "o efeito preclusivo decorrente de uma cadeia de vinculação que importa na continuidade tendencial de uma posição jurídica" (CABRAL. Antônio do Passo. Coisa julgada e preclusões dinâmicas: entre continuidade, mudança e transições de posições processuais estáveis. 2. ed. Salvador: Juspodivm, 2014, p. 355). 
ordinários e extraordinários dependendo do trânsito em julgado, mas não fazia sentido no ordenamento pátrio. ${ }^{105}$

Conquanto, de acordo com a doutrina majoritária e nos moldes do novo diploma processual civil, pode-se entender a coisa julgada como a autoridade (e não eficácia) que encobre de imutabilidade e indiscutibilidade a decisão meritória e seus efeitos. Tal autoridade só se manifestará quando a decisão judicial se tornar irrecorrível, ou seja, passar em julgado. Isso porque, no momento em que ela é prolatada, constituirá somente uma proposta de solução da controvérsia (decisão meritória), ou uma proposta de extinção do processo (decisão terminativa), sendo passível de modificação. ${ }^{106}$

\subsection{Coisa julgada material e formal}

O termo "coisa julgada" sem qualquer qualificação é usualmente empregado como sinônimo de coisa julgada material (e, assim foi utilizado até o presente momento neste projeto de monografia). ${ }^{107}$ Contudo, é essencial, neste ponto, a realização de uma análise mais apurada acerca da distinção entre as duas espécies de coisa julgada: formal e material.

Em que pese o Novo Código de Processo Civil se limitar a conceituar a coisa julgada material como a autoridade que torna imutável e indiscutível a decisão de mérito não mais sujeita a recurso (art. 502, CPC) ${ }^{108}$, sem fazer menção à coisa julgada formal, esta é tradicionalmente tratada pelos processualistas.

\footnotetext{
${ }^{105}$ CABRAL, Antonio do Passo. Coisa julgada. In: WAMBIER, Teresa Arruda Alvim et al (coord.). Breves comentários ao Novo Código de Processo Civil. EDIÇÃO. São Paulo: Revista dos Tribunais, 2015. p. 1281.

106 DINAMARCO, Cândido Rangel. Cândido Rangel. Instituições de direito processual civil. v. 3. $7^{\mathrm{a}}$ ed. São Paulo: Malheiros, 2017. p. 354.

107 BUENO, Cassio Scarpinella. Curso sistematizado de direito processual civil: Procedimento comum ordinário e sumário. v. 2, 7ª ed. São Paulo: Saraiva, 2014. p. 376.

${ }^{108}$ BRASIL. Lei n. 13.105, de 16 de março de 2015. Código de Processo Civil. Brasília, 16 de mar. 2015. Disponível em: <http://www.planalto.gov.br/ccivil_03/_ato20152018/2015/lei/113105.htm>. Acesso em 15 de abr. 2019.
} 
A distinção entre a coisa julgada material e coisa julgada formal está tão somente no grau de um mesmo fenômeno. ${ }^{109}$ Em linhas gerais, pode-se dizer que a coisa julgada formal representa a imutabilidade dos efeitos da sentença “dentro" do processo, como uma estabilidade endoprocessual ${ }^{110}$. Isso apenas impediria a reapreciação da matéria no mesmo feito. ${ }^{111} \mathrm{~A}$ coisa julgada material, por sua vez, seria a imutabilidade dos efeitos de uma sentença de mérito, que incidem para "fora" do processo, vedando-se o reexame da discussão não apenas no mesmo feito, mas em qualquer outro. ${ }^{112}$

\section{Como bem esclarece Antônio do Passo Cabral:}

"A coisa julgada formal é endógena, a coisa julgada material operaria efeitos para além do processo porque a norma do direito material passa a ser aquela decidida no caso (lex especialis)". ${ }^{113}$

$\mathrm{Na}$ verdade, por ter uma feição e uma missão exclusivamente técnicoprocessual $^{114}$, se entende que a coisa julgada formal nada mais é que um aspecto do instituto da coisa julgada (material). ${ }^{115} \mathrm{~A}$ relação entre a coisa julgada material e formal não seria antagônica, mas sim de pressuposição. ${ }^{116}$

Desta forma, a material só se constituirá após a formação da cosia julgada formal. Neste sentido, afirma o mestre Humberto Theodoro Junior que "a coisa julgada material só pode ocorrer de par com a coisa julgada

\footnotetext{
109 THEODORO JÚNIOR, Humberto. Op. cit. p. 1146.

${ }^{110}$ DIDIER JÚNIOR, Fredie; BRAGA, Paula Sarno; OLIVEIRA, Rafael Alexandria de. Curso de Direito Processual Civil: Teoria da prova, Direito probatório, Decisão, Precedente, Coisa Julgada e Tutela Provisória. v. 2. 13 ${ }^{\text {a }}$ ed. Salvador: Juspodivm. 2018. p. 596.

${ }^{111}$ CABRAL, Antonio do Passo. Coisa julgada. In: WAMBIER, Teresa Arruda Alvim et al (coord.). Breves comentários ao Novo Código de Processo Civil. EDIÇÃO. São Paulo: Revista dos Tribunais, 2015.p. 1.282.

112 BUENO, Cassio Scarpinella. Curso sistematizado de direito processual civil: Procedimento comum ordinário e sumário. v. 2, $7^{\text {a }}$ ed. São Paulo: Saraiva, 2014. p. 376/377.

${ }^{113}$ CABRAL, Antonio do Passo. Coisa julgada. In: WAMBIER, Teresa Arruda Alvim et al (coord.). Breves comentários ao Novo Código de Processo Civil. EDIÇÃO. São Paulo: Revista dos Tribunais, 2015. p. 1.282.

${ }^{114}$ DINARMACO, Cândido Rangel. Instituições de direito processual civil. v. 3. $7^{\mathrm{a}}$ ed. São Paulo: Malheiros, 2017. p. 358.

${ }^{115}$ Ibid. p. 358.

${ }^{116}$ CABRAL, Antonio do Passo. Coisa julgada. In: WAMBIER, Teresa Arruda Alvim et al (coord.). Breves comentários ao Novo Código de Processo Civil. EDIÇÃO. São Paulo: Revista dos Tribunais, 2015. p. 1.282 .
} 
formal, isto é, toda sentença para transitar materialmente em julgado deve, também, passar em julgado formalmente”. 117

Além disso, a doutrina entende que a formação da coisa julgada formal se aplica a qualquer sentença. Segundo Barbosa Moreira:

"Nenhuma decisão deixa de produzir coisa julgada ao menos do sentido formal, pois inexiste, no direito dos países ocidentais, série infinita de recursos, e portanto não há processo que, em dado momento, não se encerre, tornando-se imutáveis, no seu âmbito, as decisões nêle proferidas. Ora, a essa imutabilidade corresponde, por definição, a coisa julgada formal." 118

Do mesmo modo, Dinamarco afirma:

"Toda e qualquer sentença é apta a receber a coisa julgada formal, porque todas elas têm o efeito programado de pôr fim à fase cognitiva do processo, julgando-lhe o mérito ou estabelecendo que o mérito não será julgado (CPC, art. 203, $\S 1^{\circ}$, c/c arts. 485 e 487 - supra nn. 763-764), e, quando nenhum recurso tem cabimento ou o cabível não é interposto, o litígio posto em juízo se reputa definitivamente definido e nenhuma outra se proferirá naquele processo." 119

Após este introito imprescindível ao entendimento da matéria, devese explicitar ambos os institutos de forma mais detalhada, a começar pela coisa julgada formal.

A coisa julgada formal seria a imutabilidade da decisão como ato jurídico processual. ${ }^{120}$ Ela é ao mesmo tempo fator impeditivo da substituição da sentença por outra no mesmo processo e resultado da inadmissibilidade de qualquer recurso, ${ }^{121}$ seja porque a lei não mais o admita, seja porque se esgotou o prazo legalmente estipulado, seja porque o recorrente desistiu do recurso interposto ou ainda, renunciou à sua interposição. ${ }^{122}$

\footnotetext{
117 THEODORO JÚNIOR, Humberto. Op. cit. p. 1145

${ }^{118}$ BARBOSA MOREIRA, José Carlos. Ainda e sempre coisa julgada. In: BARBOSA MOREIRA, Jose Carlos. Direito Processual Civil (Ensaios e Pareceres). Rio de Janeiro: Borsoi. 1971.p. 143. ${ }^{119}$ DINAMARCO, Cândido Rangel. Instituições de direito processual civil. v. 3. $7^{\mathrm{a}}$ ed. São Paulo: Malheiros, 2017. p. 358.

${ }^{120}$ Ibid. p. 358.

${ }^{121}$ Ibid. p. 359

${ }^{122}$ THEODORO JÚNIOR. Humberto. Op. cit. p. 1145
} 
Theodoro Junior conceitua a coisa julgada formal como " $a$ modalidade de coisa julgada que impede o juiz de reapreciar, dentro do mesmo processo as questões decididas (CPC, art. 505). ",123

Segundo Dinamarco, esse impedimento de provocar ou emitir nova decisão no processo nada mais é que a preclusão. ${ }^{124}$ Exatamente pelo fato dessa preclusão se projetar em todo o processo para impedir que nele se tome qualquer outra decisão sobre a causa, uma parte da doutrina passou a utilizar o termo "preclusão máxima" para designar a coisa julgada formal. ${ }^{125} \mathrm{Com}$ efeito, pode se dizer que a coisa julgada formal consiste simplesmente no trânsito em julgado da decisão. ${ }^{126}$

Dinamarco também assevera que os momentos de formação da coisa julgada formal - são os mais variados. Em caso de preclusão temporal, a sentença ou a decisão interlocutória passaria em julgado no momento em que transcorreu o prazo para interposição do recurso cabível, sem que ele seja interposto. $^{127} \mathrm{Na}$ preclusão lógica, a decisão transitaria em julgado nas hipóteses de renúncia ao direito de interposição do recurso ou de aquiescência a decisão proferida. ${ }^{128}$ Por fim, se daria o trânsito em julgado

\footnotetext{
${ }^{123}$ Ibid. p. 1145.

${ }^{124}$ Fredie Didier Junior, Ovídio A. Baptista da Silva e Cassio Scarpinella Bueno reconhecem que a coisa julgada formal é uma espécie de preclusão, ou ao menos, um conceito muito próximo ao da preclusão. Luiz Guilherme Marinoni, Sergio Cruz Arenhart e Daniel Mitidier afirmam que deve se distinguir coisa julgada de preclusão - e não coisa julgada material de coisa julgada formal. Segundo eles refere a doutrina que "as próprias expressões coisa julgada material e coisa julgada formal carecem de sentido, quando vistas em uma perspectiva mais atenta. Se cosia julgada advém da expressão res iudicata, que de seu turno indica que a causa - o mérito - foi julgado, então de um lado a expressão coisa julgada material é tautológica (porque apenas procura repetir o adjetivo material algo que a locução já expressa) e, de outro, a expressão coisa julgada formal é contraditória (porque refere que a coisa - o mérito - na verdade não foi julgado)". CHIOVENDA. Giuseppe. Cosa giudicata e preclusione. Saggo di dirrito processuale civile. v. 3. Milano: Giufrfré, 1993 apud. MARINONI. Luiz Guilherme; ARENHART, Sérgio Cruz; MITIDIERO, Daniel. Novo Curso de Processo Civil: Tutela de direitos mediante procedimento comum. v. 2. $2^{\mathrm{a}}$ ed. São Paulo: Revista dos Tribumais, 2015. p. 621.

${ }^{125}$ DINAMARCO, Cândido Rangel. Instituições de direito processual civil. v. 3. $7^{\mathrm{a}}$ ed. São Paulo: Malheiros, 2017. p. 359.

${ }^{126}$ MARINONI. Luiz Guilherme; ARENHART, Sérgio Cruz; MITIDIERO. Daniel. Novo Curso de Processo Civil: Tutela de direitos mediante procedimento comum. v. 2. $2^{\mathrm{a}}$ ed. São Paulo: Revista dos Tribunais, 2015. p. 621.

${ }^{127}$ DINAMARCO. Cândido Rangel. Instituições de direito processual civil. v. $4.4^{\mathrm{a}}$ ed. São Paulo: Malheiros, 2004. p. 361.

${ }^{128}$ Ibid. p. 362
} 
por preclusão consumativa, quando último recurso cabível já foi interposto ou julgado. ${ }^{129}$

Como já relatado acima, a coisa julgada formal é um pressuposto da coisa julgada material, mas é evidente que ela pode existir sozinha. Quando a sentença se restringe a decidir sobre questões processuais, extinguindo-se o feito sem julgamento do mérito (decisão terminativa), a imutabilidade será um fenômeno meramente processual, não influenciando nas relações externas ao processo. Neste caso, o processo apenas deixa de existir e as partes poderão, inclusive, voltar com a mesma controvérsia para nova apreciação do judiciário. ${ }^{130}$

Por outro lado, se a decisão resolve o mérito da causa, será, após o trânsito em julgado formal, atingida por um maior grau de estabilidade denominado de coisa julgada material (artigo 505 do CPC). Isso porque, quando a sentença contém uma decisão meritória e, consequentemente, projeta seus efeitos para fora do processo e sobre a vida dos integrantes daquela relação processual, a coisa julgada não se cuida apenas em preservar a decisão de eventuais questionamentos no processo, mas também de assegurar os direitos, obrigações e deveres dos litigantes. ${ }^{131}$

No Código de Processo Civil de 2015, o legislador expressamente previu que a coisa julgada "material" não recai apenas sob a "sentença", mas a “decisão de mérito". No Código de 1973, o legislador mencionava genericamente "sentença", de modo que o processualista fossem obrigados a se voltar as regras concernentes a ação rescisória, que previa a rescisão da “sentença de mérito" (art. 485, caput do CPC/1973) ${ }^{132}$, para verificar a

\footnotetext{
${ }^{129}$ Ibid. p. 363.

${ }^{130}$ Ibid. p. 355.

${ }^{131}$ Ibid. p. 355.

132 BRASIL. Lei n. 5.869, de 11 de janeiro de 1973. Código de Processo Civil. Brasília. 11 jan. 1973. Disponível em: < http://www.planalto.gov.br/ccivil_03/leis/15869impressao.htm>. Acesso em 15 abr. 2019.
} 
ligação entre a coisa julgada material e as sentenças que deliberam sobre o direito material. ${ }^{133}$

Ao utilizar o termo "decisão", o novo CPC abrange não apenas sentenças, como também acórdãos, decisões unipessoais e até mesmo decisões interlocutórias que julgam antecipadamente o mérito da causa. Frisa-se, neste ponto, que o novel CPC rompeu com a lógica de impossibilidade de fracionamento do mérito, o que significa que atualmente existe a possibilidade de julgamento parcial do mérito através de decisões interlocutórias, que poderão ser acobertadas pela coisa julgada. ${ }^{134}$

Essas decisões serão suscetíveis à formação de coisa julgada material se se fundam em cognição exauriente; resolvem o mérito da causa; e passam em julgado (coisa julgada formal). ${ }^{135}$ São insuscetíveis, por outro lado, à formação da coisa julgada material: (i) as decisões terminativas; (ii) os despachos e decisões interlocutórias sobre questões diversas ao mérito; (iii) as decisões prolatadas em sede de jurisdição voluntária; (iv) as decisões provisórias em tutela de urgência e evidência, que podem ser revogadas ou modificadas a qualquer tempo. ${ }^{136}$

É de se notar que a ausência de amparo da coisa julgada material não significa que estas decisões estão completamente vulneráveis a qualquer tipo de modificação. Na verdade, a coisa julgada material é o maior grau de estabilização dos atos processuais, de sorte que ela não é a única barreira imunizadora. ${ }^{137}$

\footnotetext{
${ }^{133}$ CABRAL, Antônio do Passo. Coisa julgada. In: WAMBIER, Teresa Arruda Alvim et al (coord.). Breves comentários ao Novo Código de Processo Civil. São Paulo: Revista dos Tribunais, 2015. p. 1283.

${ }^{134}$ Ibid. 1282.

${ }^{135}$ DIDIER JÚNIOR, Fredie; BRAGA, Paula Sarno; OLIVEIRA, Rafael Alexandria de. Op. cit. p. $594 / 595$

${ }^{136}$ THEODORO JÚNIOR, Humberto. Op. cit. p. 1147.

${ }^{137}$ DINAMARCO, Cândido Rangel. Instituições de direito processual civil. v. 3. $7^{\mathrm{a}}$ ed. São Paulo: Malheiros, 2017. p. 369.
} 
Inclusive, o Código de Processo Civil inovou muito no que concerne o sistema de estabilidades, desconstituindo a ideia de que a coisa julgada é a "estabilidade por excelência”, mas sim uma "espécie" de estabilidade. ${ }^{138}$

Portanto, a coisa julgada formal atua dentro do processo, sem ao menos impedir que o objeto do julgamento volte a ser discutido em outros litígios. Enquanto a coisa julgada material tem força de lei (art. 503, CPC), produzindo efeitos no mesmo processo e em quaisquer outros. ${ }^{139}$

\subsection{Efeito positivo e negativo da coisa julgada}

A coisa julgada material estabilizará a decisão proferida no processo, de maneira a extinguir em definitivo a incerteza provocada pela lide instalada pelas partes. Essa decisão não apenas será conhecida pelos sujeitos processuais, como também será imposta a eles, com força de lei. ${ }^{140}$

Uma vez cristalizada a situação jurídica, a coisa julgada pode ser vista em duas funções, de um lado, ela impedirá o restabelecimento da mesma controvérsia e de outro vinculará de forma definitiva as partes. ${ }^{141}$ À primeira destas funções ou efeitos, é dado o nome de negativa e à segunda, positiva.

O efeito negativo consiste na proibição de novo julgamento sobre a mesma demanda ou demanda idêntica, que contenha mesmas partes, mesma causa de pedir e o mesmo pedido, devendo, neste caso, o segundo processo ser extinto sem o julgamento do mérito (CPC, art. 337 inc. VII e $\S \S 1^{\circ}, 2^{\circ}$ e $4^{\mathrm{o}}, \mathrm{c} / \mathrm{c}$ art. 485 inc. V). ${ }^{142}$ Neste sentido, como diz Ovídio Baptista, a coisa

\footnotetext{
${ }^{138}$ CABRAL, Antonio do Passo. Coisa julgada. In: WAMBIER, Teresa Arruda Alvim et al (coord.). Breves comentários ao Novo Código de Processo Civil. São Paulo: Revista dos Tribunais, 2015. p. 1.282.

139 THEODORO JÚNIOR, Humberto. Op. cit. p. 1152.

${ }^{140}$ Ibid. p. 1152.

${ }^{141}$ Ibid. p. 1153.

${ }^{142}$ DINAMARCO, Cândido Rangel. Instituições de direito processual civil. v. 3. $7^{\mathrm{a}}$ ed. São Paulo: Malheiros, 2017. p. 357.
} 
julgada atuaria como "rei iudicatae, ou seja, uma defesa, para impedir novo julgamento daquilo que fora decidido na demanda anterior". ${ }^{143}$

O julgamento do novo processo seria uma violação ao princípio da economia processual, como também, à harmonização dos julgados. Mesmo que a segunda demanda proposta fosse decidida no mesmo sentido que a primeira, nada justificaria sua tramitação. ${ }^{144}$

O efeito positivo, por outro lado, corresponderia a utilização do conteúdo da coisa julgada como fundamento para posterior demanda. ${ }^{145}$ Didier afirma que o efeito positivo seria a "vinculação do julgador (de uma segunda causa) ao quanto decidido na causa em que a coisa julgada foi proferida. ${ }^{146}$

Dinamarco vincula tal função à prejudicialidade, esclarecendo que a função positiva seria a imposição do preceito dito na sentença de mérito transitada em julgado como um ponto inquestionável em outro processo, sempre que fosse objeto de uma relação de prejudicialidade. ${ }^{147}$

Neste sentido, o seguinte exemplo trazido por Didier:

“(...) em ação de alimentos lastreada em coisa julgada de filiação, o juiz não pode negar os alimentos, sob o fundamento que não existe vínculo de família - pode negar os alimentos, mas não por esse fundamento, pois sobre a existência de filiação já há coisa julgada". ${ }^{148}$

Theodoro Junior esclarece, a título conclusivo, que a imutabilidade e a indiscutibilidade prevista no artigo 502 do Código de Processo Civil referem-se a estes dois aspectos distintos, quais sejam: (i) imutabilidade

\footnotetext{
${ }^{143}$ SILVA, Ovídio A. Baptista da. Curso de Processo Civil. Processo de Conhecimento. v. 1. $3^{\circ}$ ed. São Paulo: Revista dos Tribunais, 2000. p.500.

${ }^{144}$ NEVES, Daniel Amorim Assumpção. Manual de Direito Processual Civil. $9^{\mathrm{a}}$ edição. Salvador: Juspodivm, 2017. p.881.

${ }^{145}$ SILVA, Ovídio A. Baptista da. Curso de Processo Civil. Processo de Conhecimento. v. 1. $3^{\circ}$ Ed. São Paulo: Revista dos Tribunais, 2000. p. 500.

${ }^{146}$ DIDIER JUNIOR, Fredie. Coisa julgada. In: CABRAL, Antonio do Passo; CRAMER, Ronaldo. Comentários ao Novo Código de Processo Civil. $2^{\mathrm{a}}$ ed. Rio de Janeiro: Forense, 2016. p. 752.

${ }^{147}$ DINAMARCO, Cândido Rangel. Instituições de direito processual civil. v. 3. $7^{\text {a }}$ ed. São Paulo: Malheiros, 2004. p. 357.

${ }^{148}$ DIDIER JÚNIOR, Fredie; BRAGA, Paula Sarno; OLIVEIRA, Rafael Alexandria de. Op. cit. p. 592.
} 
como impedimento para que as partes proponham demanda idêntica àquela que já está coberta pela coisa julgada, como efeito negativo; e (ii) indiscutibilidade como proibição de que o juiz de novo processo, no qual a causa de pedir seja uma situação jurídica anteriormente decidida e já transitada em julgado, não reexamine-a, mas sim tome-a como "premissa indiscutível", como efeito positivo. ${ }^{149}$

\subsection{Limites da coisa julgada}

Um dos aspectos mais relevantes do estudo da coisa julgada é a extensão dos seus limites objetivos, subjetivos e temporais.

\subsubsection{Limites objetivos da coisa julgada}

Por limites objetivos se entende a "parte" do decisium que ficará acobertada pela autoridade da coisa julgada, ou melhor, "o que não pode ser rediscutido perante o Estado-juiz pelo prevalecimento da segurança jurídica". ${ }^{150}$

Para delimitar "o quê" se torna indiscutível com a coisa julgada, é imperioso rememorar que a sentença é compota por três partes: o relatório, a motivação e o dispositivo. ${ }^{151}$ Segundo arraigado entendimento doutrinário, apenas o preceito concreto contido na parte dispositiva da decisão meritória seria acobertado pela autoridade da coisa julgada e não os motivos que a fundamentam. ${ }^{152}$

Assim a res judicata não incidiria na sentença como um todo, pois os motivos, apesar de relevantes, restringem-se ao plano lógico de elaboração do julgado. Desta forma, a parte que se tornaria imutável e indiscutível

\footnotetext{
${ }^{149}$ THEODORO JÚNIOR, Humberto. Op. cit. p. 1153.

${ }^{150}$ BUENO, Cassio Scarpinella. Op. cit. p. 377.

${ }^{151}$ THEODORO JÚNIOR, Humberto. Op. cit. p. 1160.

${ }^{152}$ DINAMARCO, Cândido Rangel. Instituições de direito processual civil. v. 3. $7^{\mathrm{a}}$ ed. São Paulo: Malheiros, 2017. p. 375.
} 
abrangeria tão somente a resposta ao pedido do autor, não o "porquê" dessa resposta. $^{153}$

Nesse sentido, Dinamarco afirma:

"Existe um eixo imaginário que liga o pedido posto na demanda inicial e a parte dispositiva da sentença, de modo que o autor pede determinada providência em relação a determinado bem da vida e o juiz lhe responde concedendo ou denegando essa providência. É nessa resposta e não nas razões adotadas pelo juiz para responder, que reside a fórmula de convivência a ser observada pelos sujeitos envolvidos no conflito." 154

Essa limitação da coisa julgada ao dispositivo da decisão advém da concepção estabelecida por Karl Heinz Schwab ${ }^{155}$ de que o objeto litigioso corresponde a matéria que será decidida principaliter no processo - o pedido principal. ${ }^{156}$ Assim, dispõe o artigo 503 do Código de Processo Civil que " $a$ decisão que julgar total ou parcialmente o mérito tem força de lei nos limites da questão principal expressamente decidida". ${ }^{157}$

Contudo, existem correntes doutrinárias que entendem insuficiente essa visão tradicional. Alguns defendem que o objeto litigioso abrange tanto o pedido quanto a causa de pedir, o que se mostra coerente com o regramento da coisa julgada, que prescinde a identificação do pedido e causa de pedir (artigos $337, \S \S 2^{\circ}$ e $4^{\circ}$ e 508, CPC)..$^{158}$

Outros, como Didier, admitem a participação do réu no objeto litigioso, não apenas quando ele apresenta reconvenção ou pedido

\footnotetext{
${ }^{153}$ THEODORO JÚNIOR, Humberto. Op. cit. p. 1161.

${ }^{154}$ DINAMARCO, Cândido Rangel. Instituições de direito processual civil. v. $3.7^{\text {a }}$ ed. São Paulo: Malheiros, 2017. p. 377.

${ }^{155}$ SHWAB, Karl Heinz. El objeto litigioso em el processo civil. Buenos Aires: EJEA, 1968.

${ }^{156}$ CABRAL, Antonio do Passo. Coisa julgada. In: WAMBIER, Teresa Arruda Alvim et al (coord.). Breves comentários ao Novo Código de Processo Civil. São Paulo: Revista dos Tribunais, 2015.p. 1.288. O Novo Código de Processo Civil adotou o advérbio "expressamente" para evitar coisa julgada implícita e construções teóricas como a consolida no enunciado de Súmula 453 do STJ, o qual dispõe: "Os honorários sucumbenciais, quando omitidos em decisão transitada em julgado, não podem ser cobrados em execução ou em ação própria." DIDIER JÚNIOR, Fredie; BRAGA, Paula Sarno; OLIVEIRA, Rafael Alexandria de. Op. cit. p. 604.

${ }^{157}$ BRASIL. Lei n. 13.105, de 16 de março de 2015. Código de Processo Civil. Brasília, 16 mar. 2015. Disponível em: <http://www.planalto.gov.br/ccivil_03/_ato20152018/2015/lei/113105.htm>. Acesso em: 15 abr. 2019.

${ }^{158}$ DIDIER JUNIOR, Fredie. Coisa julgada. In: CABRAL, Antonio do Passo; CRAMER, Ronaldo. Comentários ao Novo Código de Processo Civil. $2^{\mathrm{a}}$ ed. Rio de Janeiro: Forense, 2016. p. 749.
} 
contraposto, mas também no momento de exercício do contradireito (compensação, exceção de contrato não cumprido e prescrição, por exemplo). ${ }^{159}$

De qualquer forma, o legislador foi categórico ao estipular nos incisos do artigo 504 do Código de Processo Civil que não fazem coisa julgada (i) os motivos, ainda que importantes para determinar o alcance da parte dispositiva da sentença; e (ii) a verdade dos fatos, estabelecida como fundamento da sentença. ${ }^{160}$

No pretérito diploma processual, além desses dois incisos, se excluía da incidência da coisa julgada "a apreciação da questão prejudicial, decidida incidentalmente no processo" (art. 469, inciso III do Código de Processo Civil de $\left.1973^{161}\right)$. Assim, a questão prejudicial só poderia ser dotada de imutabilidade e indiscutibilidade caso fosse ajuizada a ação declaratória incidental. O Código de Processo Civil de 2015, por outro lado, adota novo regramento acerca da questão prejudicial, admitindo a incidência da coisa julgada quando observados certos requisitos previstos no parágrafo $1^{\circ}$ e $2^{\circ}$ do artigo 504 do referido diploma. ${ }^{162}$ Frisa-se que a coisa julgada de questão prejudicial será aprofundada no próximo capítulo.

\subsubsection{Limites subjetivos da coisa julgada}

Os limites subjetivos da coisa julgada dizem respeito a "quem” está sujeito a estabilidade inerente ao trânsito em julgado. ${ }^{163} \mathrm{~A}$ regra geral é

\footnotetext{
${ }^{159}$ DIDIER JÚNIOR, Fredie; BRAGA, Paula Sarno; OLIVEIRA, Rafael Alexandria de. Op. cit. p. 603.

${ }^{160}$ BRASIL. Lei n. 13.105, de 16 de março de 2015. Código de Processo Civil. Brasília, 16 mar. 2015. Disponível em: <http://www.planalto.gov.br/ccivil_03/_ato20152018/2015/lei/113105.htm>. Acesso em: 15 abr. 2019.

${ }^{161}$ Art. 469. Não fazem coisa julgada:

I - os motivos, ainda que importantes para determinar o alcance da parte dispositiva da sentença;

Il - a verdade dos fatos, estabelecida como fundamento da sentença;

II2 - a apreciação da questão prejudicial, decidida incidentemente no processo.

${ }^{162}$ DINAMARCO, Cândido Rangel. Instituições de direito processual civil. v. $3.7^{\mathrm{a}}$ ed. São Paulo: Malheiros, 2017. p. 376.

${ }^{163}$ DIDIER JÚNIOR, Fredie; BRAGA, Paula Sarno; OLIVEIRA, Rafael Alexandria de. Op. cit. p. 624.
} 
consagrada no artigo 506 do Código de Processo Civil, segundo o qual " $a$ sentença faz coisa julgada às partes entre as quais é dada, não prejudicando terceiro.

O novel Código de Processo Civil traz mudança ao proibir apenas a incidência dos efeitos prejudiciais aos terceiros, e não de quaisquer efeitos sejam benéficos, sejam prejudiciais - res inter alios acta nec nocet nec prodesta ${ }^{164}$ - , tal como previsto no pretérito Código. ${ }^{165}$ Segundo Antônio do Passo Cabral, em que pese a alteração ser oportuna, por permitir que os terceiros se beneficiem, é notadamente contrária a tendência mundial de impedimento de eficácia estendida para além das partes. ${ }^{166}$

De uma leitura atenta ao dispositivo em apreço, extrai-se a conclusão que a coisa julgada se opera inter partes, de forma que a autoridade da decisão transitada em julgado vai se impor para aqueles que figuraram como parte no processo, assim como seus sucessores. ${ }^{167}$

Essa restrição subjetiva à coisa julgada se alicerça no princípio do devido processo legal, ampla defesa e contraditório (art. $5^{\circ}, \mathrm{XXXV}, \mathrm{LIV}$ e $\mathrm{LV}$ da $\mathrm{CF}$ ). Isso porque, ninguém poderá ser atingido por efeitos desfavoráveis de uma decisão, sem que lhe seja oportunizado a participação do contraditório na condição de parte do processo. ${ }^{168}$

Há exceções a essa regra geral, em hipóteses em que a coisa julgada opera ultra partes ou erga omnes. ${ }^{169}$

\footnotetext{
${ }^{164}$ GRECO FILHO, Vicente. Direito processual civil brasileiro. v. 2. 16ª ed. São Paulo: Saraiva, 2003. p. 253.

${ }^{165}$ Ibid. p. 625

${ }^{166}$ CABRAL, Antonio do Passo. Coisa julgada. In: WAMBIER, Teresa Arruda Alvim et al (coord.). Breves comentários ao Novo Código de Processo Civil. São Paulo: Revista dos Tribunais, 2015. p. 1.304.

${ }^{167}$ DIDIER JÚNIOR, Fredie; BRAGA, Paula Sarno; OLIVEIRA, Rafael Alexandria de. Op. cit. p. 624/625. Didier salienta que não apenas as partes, mas também o Ministério Público como fiscal da ordem jurídica é vinculado pela decisão transitada em julgado (STJ, $4^{\mathrm{a}} \mathrm{T}$., Resp n. 1.155.793, rela. Min. Isabel Gallotti, julgado em 01.10.2013, publicado no DJe de 11.10.2013).

${ }^{168}$ DINAMARCO, Cândido Rangel. Instituições de direito processual civil. v. 3. $7^{\mathrm{a}}$ ed. São Paulo: Malheiros, 2017. p. 384 e DIDIER JÚNIOR, Fredie; BRAGA, Paula Sarno; OLIVEIRA, Rafael Alexandria de. Op. cit. p. 625.

${ }^{169}$ DIDIER JÚNIOR, Fredie; BRAGA, Paula Sarno; OLIVEIRA, Rafael Alexandria de. Op. cit. p. 625.
} 
A coisa julgada será eficaz ultra partes, nos casos em que atingir não somente as partes do processo, mas terceiros. São várias as situações que os efeitos da coisa julgada serão estendidos a terceiros, como na substituição processual, em que o substituído será atingido pelos efeitos da coisa julgada, mesmo não figurando como parte; na dissolução parcial de sociedade, na qual a sociedade ainda que não citada se submete a coisa julgada (art. 601, parágrafo único, CPC); decisão favorável a um dos credores solidários (artigo 274, $\mathrm{CC}^{170}$ ); substituição processual ulterior de adquirente/cessionário (artigo 109, $\S 3^{\circ}$ do CPC); e ações coletivas que versam sobre direitos coletivos stricto senso (artigo 103, II CDC $\left.{ }^{171}\right) .{ }^{172}$

Em outro giro, terá efeitos erga omnes, a decisão que abranger todos os jurisdicionados, como nos casos de ações de controle concentrado de constitucionalidade e ações coletivas tratando de direitos difusos ou individuais homogêneos (artigo 103, I e III do $\mathrm{CDC}^{173}$ ). Essa classificação doutrinária é alvo de críticas, visto a inviabilidade de uma decisão submeter a todos indistintamente a ponto de ter eficácia erga omnes. ${ }^{174}$

Frisa-se que o fato recorrente de terceiros que não figuraram como partes de determinada demanda judicial sofrerem efeitos da decisão proferida pelo órgão jurisdicional - como no caso de um sublocatário ser prejudicado pelos efeitos nefastos da procedência do pedido do locador em face do locatário - não se contrapõe a limitação subjetiva acima analisada. ${ }^{175}$

\footnotetext{
${ }^{170}$ BRASIL. Lei n. 10.406, de 10 de janeiro de 2002. Código Civil. Brasília, 10 jan. 2002. Disponível em: <http://www.planalto.gov.br/ccivil_03/LEIS/2002/L10406.htm> Acesso em: 20 de abr. de 2019.

${ }^{171}$ BRASIL. Lei 8.078, de 11 de setembro de 1990. Código de Defesa do Consumidor. 11 set. 1990. Disponível em: <http://www.planalto.gov.br/ccivil_03/LEIS/L8078.htm> Acesso em: 20 de ab. de 2019.

172 Ibid. p. 625-626.

${ }^{173}$ BRASIL. Lei 8.078, de 11 de setembro de 1990. Código de Defesa do Consumidor. 11 set. 1990. Disponível em: <http://www.planalto.gov.br/ccivil_03/LEIS/L8078.htm> Acesso em: 20 de ab. de 2019.

${ }^{174}$ Ibid. p. 627.

${ }^{175}$ CABRAL, Antonio do Passo. Coisa julgada. In: WAMBIER, Teresa Arruda Alvim et al (coord.). Breves comentários ao Novo Código de Processo Civil. São Paulo: Revista dos Tribunais, 2015. p. 1.302 .
} 
Partindo do entendimento liebmiano, no qual a eficácia natural da sentença diferencia-se da autoridade da coisa julgada, os efeitos da decisão passada em julgado poderão atingir terceiros, mas a imutabilidade e indiscutibilidade inerentes à coisa julgada atuará apenas sob as partes do processo. $^{176}$

\subsubsection{Limites temporais da coisa julgada}

Por fim, é evidente que a coisa julgada não é eterna ${ }^{177}$ e são os seus limites temporais que delimitarão a sua duração, ou melhor, "até quando" a decisão se revestirá do manto de estabilidade. ${ }^{178}$

Dispõe o artigo 505 que a nenhum juiz decidirá novamente as questões já decididas relativas à mesma lide, salvo: (i) se, tratando-se de relação jurídica de trato continuado, sobreveio modificação no estado de fato ou de direito, caso em que poderá a parte pedir a revisão do que foi estatuído na sentença; (ii) nos demais casos prescritos em lei.

$\mathrm{O}$ inciso I menciona as relações jurídicas de trato continuado. Para melhor compreensão do tema, cabe ressaltar que as relações jurídicas podem ser classificadas em instantâneas, permanentes e sucessivas. A relação jurídica instantânea é aquela que decorre de fato gerador instantaneamente esgotável em momento determinado, sem continuidade temporal, como ação de ressarcimento por danos materiais. A relação jurídica permanente é aquela referente à situação que se estende com o tempo, como obrigação previdenciárias e de pagar alimentos. Enquanto, que as sucessivas são

\footnotetext{
${ }^{176}$ LIEBMAN, Enrico Tullio. Op. cit. p. 132.

${ }^{177}$ CABRAL, Antonio do Passo. Coisa julgada. In: WAMBIER, Teresa Arruda Alvim et al (coord.). Breves comentários ao Novo Código de Processo Civil. São Paulo: Revista dos Tribunais, 2015. p. 1.298 .

${ }^{178}$ DIDIER JÚNIOR, Fredie; BRAGA, Paula Sarno, OLIVEIRA, Rafael Alexandria de. Op. cit. p. 634.
} 
"nascidas de fatos geradores instantâneos que, todavia, se repetem no tempo de maneira uniforme e continuada", como obrigações tributárias. ${ }^{179}$

Segundo Didier, as decisões que versam sobre relações jurídicas permanentes ou sucessivas contêm uma cláusula rebus sic stantibus, em que "havendo modificação superveniente no estado de fato ou de direito, é lícito rever o quanto se decidiu’. 180

Para a melhor doutrina, não é correto afirmar que, em virtude dessa possibilidade de reexame, as decisões que tratam de relações de trato sucessivo (permanentes e sucessivas) não transitam materialmente em julgado. Ora, a modificação superveniente de fato ou de direito pode dar ensejo a uma nova ação (ação de revisão ou ação de modificação), que conterá pedido e causa de pedir distintos, de modo a não afetar a coisa julgada formada no processo originário. ${ }^{181}$

De acordo com Theodoro Junior:

“(...) o acertamento do feito, em face da situação fático-jurídica apurada no tempo da sentença. continuará imutável e indiscutível, para sempre. Se algum novo julgamento vier a acontecer entre as partes, já não será sobre o mesmo objeto, visto que a relação jurídica litigiosa estará envolvendo elementos novos que não foram apreciados na sentença anterior." 182

O inciso II se refere aos outros instrumentos, previstos em lei, de controle da coisa julgada. Dentre os mais conhecidos, cita-se (i) a ação rescisória (artigos 966 e seguintes do CPC) e (ii) a querela nullitatis (artigo $525, \S 1^{\circ}$, inciso I e artigo 535, I, CPC). A ação rescisória é uma ação autônoma de impugnação de decisão de mérito transitada em julgado com base em problemas formais e injustiças, manejada no prazo decadencial de dois anos. A querela nulitatis, é o meio de impugnações intentada a qualquer tempo em casos que: (i) a decisão foi proferida em desfavor do réu, em

\footnotetext{
${ }^{179}$ ZAVASCKI, Teoria Albino. Eficácia das sentenças na jurisdição constitucional. Porto Alegra, agosto de 2000. p. 88/89.

${ }^{180}$ DIDIER JÚNIOR, Fredie; BRAGA, Paula Sarno; OLIVEIRA, Rafael Alexandria de. Op. cit. p. 626.

${ }^{181}$ Ibid. p. 626.

182 THEODORO JÚNIOR, Humberto. Op. cit. p. 1187.
} 
processo que correu a sua revelia por falta de citação e; (ii) a decisão proferida em desfavor do réu revel, em processo que correu a sua revelia por citação defeituosa. $^{183}$

Além desses instrumentos de controle da decisão transitada em julgada, há na doutrina quem defenda a utilização de meios atípicos - não previstos em lei - para a revisão ou desconstituição da res iudicata, nas hipóteses em que a solução fora injusta ou inconstitucional. ${ }^{184}$ À presente tese se dá o nome de relativização atípica da coisa julgada. ${ }^{185}$

Segundo Marinoni, os doutrinadores e juristas que defendem a "relativização" costumam se pautar nos princípios da proporcionalidade, da legalidade e da instrumentalidade. Isso porque, (i) a coisa julgada mesmo que consistente em valor esculpido na Carta Magna não pode prevalecer a outros princípios igualmente dignos de guarida; (ii) a sentença não pode se afastar do direito positivado; e (iii) o processo como instrumento da jurisdição deve necessariamente ter como base os ideais de justiça e a adequação a realidade fática. ${ }^{186}$

Para Didier, um dos principais problemas dessa concepção é a abrangência do significante "injustiça" no imaginário do judiciário do país. A relativização pode franquear ao Judiciário um "poder geral de revisão da coisa julgada, que daria margem, certamente, a interpretações das mais diversas, em prejuízo da segurança jurídica. ",187

\footnotetext{
${ }^{183}$ DIDIER JUNIOR, Fredie. Coisa julgada. In: CABRAL. Antonio do Passo; CRAMER. Ronaldo. Comentários ao Novo Código de Processo Civil. $2^{\mathrm{a}}$ ed. Rio de Janeiro: Forense, 2016. p. 775; ${ }^{184}$ BARBOSA MOREIRA, José Carlos. Considerações sobre a chamada relativização da coisa julgada material. In: DIDIER JUNIOR, Fredie (org.). Relativização da coisa julgada. $2^{\mathrm{a}}$ ed. Salvador: Juspodivm, 2008. p. 227.

${ }^{185}$ DIDIER JÚNIOR, Fredie; BRAGA, Paula Sarno; OLIVEIRA, Rafael Alexandria de. Op. cit. p. 640.

${ }^{186}$ MARINONI, Luiz Guilherme. O princípio da segurança dos atos jurisdicionais (A questão da relativização da coisa julgada material). In: DIDIER JUNIOR, Fredie (org.). Relativização da coisa julgada. $2^{\mathrm{a}}$ ed. Salvador: Juspodivm, 2008. p. 264

${ }_{187}$ DIDIER JÚNIOR, Fredie; BRAGA, Paula Sarno; OLIVEIRA, Rafael Alexandria de. Op. cit. p. 641.
} 
Apesar da teoria ser muito discutida e controvertida, o Supremo Tribunal Federal a admitiu nas hipóteses de sentenças transitadas em julgado proferidas em ações de investigação de paternidade, que entendiam pela inexistência do vínculo entre pai e filho por ausência de provas. Após o surgimento do exame de DNA, tais decisões se mostraram contrárias a realidade e eminentemente injustas, por isso passiveis de modificação ${ }^{188}$

188 (STF, RE 363.889, Rel. Min. Dias Toffoli, j. 02.06.2011). DIDIER JUNIOR, Fredie. Coisa julgada. In: CABRAL. Antonio do Passo; CRAMER. Ronaldo. Comentários ao Novo Código de Processo Civil. $2^{\mathrm{a}}$ Ed. Rio de Janeiro: Forense, 2016. p. 776. 


\section{CAPÍTULO 3. COISA JULGADA SOBRE QUESTÃO PREJUDICIAL}

No capítulo anterior foi exposto uma visão ampla do instituto da coisa julgada no novo codex de processo civil, com seus principais aspectos, sendo inclusive discriminado alguns traços comparativos com as normas positivadas dos antigos códigos. Desta forma, este tópico se reservará a exposições de comentários especificamente acerca do regramento da coisa julgada em questão prejudicial e da ação declaratório incidental nos Códigos de Processo Civis de 1939, 1973 e 2015.

\subsection{COISA JULGADA SOBRE QUESTÃO PREJUDICIAL NO CÓDIGO DE PROCESSO CIVIL DE 1939 e 1973}

\subsubsection{Panorama geral e ação declaratório incidental}

A normativa do Código de Processo Civil de 1939 acerca da coisa julgada era insuficiente e imprecisa. O caput do artigo 287 do diploma dispunha que "a sentença que decidir total ou parcialmente a lide terá força de lei nos limites das questões decididas". ${ }^{189}$ Contudo, o parágrafo único comportava interpretações variadas ao prever que "considerar-se-ão decididas todas as questões que constituam premissa necessária da conclusão ${ }^{190},{ }^{191}$

Diante desta redação inconsistente, discutia-se a real abrangência dos limites objetivos da coisa julgada, por um lado como restrita ao dispositivo da sentença, por outro, expandida unicamente ao fundamento precípuo a

\footnotetext{
${ }^{189}$ BRASIL. Decreto-Lei n. 1.608, de 18 de setembro de 1939. Código de Processo Civil. Rio de Janeiro. 18 set. 1939. Disponível em: <http://www.planalto.gov.br/ccivil_03/decreto-lei/19371946/Del1608.htm> Acesso em: 10 mar. 2019.

190 Ibid.

${ }^{191}$ ALVIM, José Eduardo Carreira. Elementos da teoria geral do processo. $2^{\mathrm{a}}$ ed. Rio de Janeiro: Forense: 1993. p. 408. José Eduardo Carreira salienta que "o preceito do CPC-39 inspirou-se no Projeto Mortara que, entretanto, dispunha: "Considerar-se-á decidida, ainda que não resolvida expressamente, toda questão cuja resolução constitua premissa da disposição contida na sentença".
} 
decisão final. ${ }^{192}$ Uma corrente minoritária defendia que a leitura do parágrafo único do artigo 287 do código levava à conclusão de que a coisa julgada incidiria sob questões prejudiciais. ${ }^{193}$

O Código Civil de 1973 fora muito mais preciso ao delinear a abrangência objetiva da res iudicata. O artigo 469 é expresso no sentido de excluir da incidência da coisa julgada não apenas os motivos, ainda que importantes para determinar o alcance da parte dispositiva da sentença (inciso I do artigo 469 do CPC/73) e a verdade dos fatos, estabelecida como fundamento da sentença (inciso II do artigo 469 do CPC/73), como também a apreciação da questão prejudicial, decidida incidentemente no processo (inciso III do artigo 469 do CPC/73). ${ }^{194}$

Neste contexto, só haveria formação da coisa julgada em relação a questão prejudicial se ela fosse decidida de forma principal (principialiter). Isso só poderia ocorrer (i) se a inicial contivesse um pedido expresso que lhe abrangesse ou (ii) através ação declaratória incidental. ${ }^{195}$

A ação declaratória incidental era disciplinada pelos artigos $5^{\mathbf{0 1 9 6}}$, $325^{197}$ e 470 do pretérito Código. Este último dispositivo previa que fazia coisa julgada a resolução da questão prejudicial, se esta constituísse pressuposto necessário para o julgamento da lide e se a parte requeresse a declaração incidental ao juízo competente.

\footnotetext{
192 Ibid. p. 408. e GRINOVER, Ada Pelegrini. Ação declaratória incidental. São Paulo: Revista dos Tribunais, 1972, 35/36.

${ }^{193}$ REDONDO, Bruno Garcia. Questões prejudiciais e limites objetivos da coisa julgada no novo CPC. Revista do Processo. vol. 248. ano 40. p. 43 - 67. São Paulo: Revista Tribunais, out. 2015. p. 48.

${ }^{194}$ BRASIL. Lei n. 5.869, de 11 de janeiro de 1973. Código de Processo Civil. Brasília. 17 jan. 1973. Disponível em: < http://www.planalto.gov.br/ccivil_03/leis/15869impressao.htm>. Acesso em 15 abr. 2019.

${ }^{195}$ DIDIER JÚNIOR, Fredie; BRAGA, Paula Sarno; OLIVEIRA, Rafael Alexandria de. Op. cit. p. 621.

${ }^{196}$ CPC/73: Art. 5ํ. Se, no curso do processo, se tornar litigiosa relação jurídica de cuja existência ou inexistência depender o julgamento da lide, qualquer das partes poderá requerer que o juiz a declare por sentença.

${ }^{197}$ CPC/73: Art. 325. Contestando o réu o direito que constitui fundamento do pedido, o autor poderá requerer, no prazo de 10 (dez) dias, que sobre ele o juiz profira sentença incidente, se da declaração da existência ou da inexistência do direito depender, no todo ou em parte, o julgamento da lide (art. $\left.5^{\circ}\right)$.
} 
Segundo Scarpinella Bueno, o "pedido incidental de declaração" não constituía nova ação, mas novo pedido formulado por qualquer das partes ${ }^{198}$, com o escopo de obter tutela jurisdicional não pedida inicialmente. ${ }^{199}$ Destarte, o pedido expresso de declaração incidental cumulava-se ao pedido principal, adquirindo um caráter eminentemente reconvencional. ${ }^{200}$

Independentemente da nomenclatura - ação ou pedido -, a declaração servia não apenas para ampliar o objeto de julgamento, como também, o objeto da decisão, revestindo a questão prejudicial da autoridade da coisa julgada. $^{201}$

\title{
Salienta Ada Pelegrinni Grinover:
}

\begin{abstract}
"Mediante a ação declaratória incidental operar-se-á a aplicação do objeto do pedido; e a questão prejudicial, que poderia constituir objeto de processo autônomo, terá sido declarada dentro de ação que verse sobre outro estado ou relação jurídica, de forma que a ela também se estende a autoridade da coisa julgada." 202
\end{abstract}

O prazo para que o autor requeresse a declaração incidental era de 10 dias após o réu contestar o ponto prejudicial alegado. Quanto ao prazo para o requerimento do réu, a lei fora omissa, mas se considerava aquele previsto para a apresentação de contestação (15 dias). ${ }^{203}$

Quanto ao procedimento, a ação declaratória incidental, quando deferida era processada nos autos principais e julgada pela mesma sentença do pedido principal - sendo proferida uma sentença formalmente una. ${ }^{204}$

\footnotetext{
198 Thereza Alvim esclarece que ao falar em "partes", a lei procurou se referir ao autor, o réu, ao oponente ou qualquer litisconsorte. ALVIM, Thereza. Questões prévias e os limites objetivos da coisa julgada. São Paulo: Revista dos Tribunais, 1977. p. 102.

199 BUENO, Cassio Scarpinella. Curso sistematizado de direito processual civil: Procedimento comum ordinário e sumário. v. 2. 5a Ed. São Paulo: Saraiva, 2012. p. 218-219

${ }^{200}$ FURTADO, Adroaldo. Op. cit. p. 116.

201 BUENO, Cassio Scarpinella. Curso sistematizado de direito processual civil: Procedimento comum ordinário e sumário. v. 2. 5a Ed. São Paulo: Saraiva, 2012. p. 218-219

202 GRINOVER, Ada Pelegrini. Ação declaratória incidental. São Paulo: Revista dos Tribunais, 1972. p. 58.

${ }^{203}$ ALVIM, Thereza. Questões prévias e os limites objetivos da coisa julgada. São Paulo: Revista dos Tribunais, 1977. p. 102.

${ }^{204}$ ALVIM, Thereza. Questões prévias e os limites objetivos da coisa julgada. São Paulo: Revista dos Tribunais, 1977. p. 104.
} 
Quando indeferida, era proferida decisão interlocutória (impugnável por agravo de instrumento) e o processo seguia apenas com o pedido principal. ${ }^{205}$

\subsection{COISA JULGADA SOBRE QUESTÃO PREJUDICIAL NO CÓDIGO DE PROCESSO CIVIL DE 2015}

\subsubsection{Distinção entre coisa julgada comum e coisa julgada especial}

Pode-se dizer que atualmente o nosso ordenamento jurídico abarca dois regimes jurídicos distintos para a formação de coisa julgada, dependendo do objeto de incidência: o regime comum e o regime especial. O regime jurídico comum ou tradicional consiste na coisa julgada de questão principal (art. 503, caput, CPC). O regime especial consiste na coisa julgada de questão prejudicial decidida de forma incidental no processo, especificamente nas situações previstas no parágrafo $1^{\circ}$ e $2^{\circ}$ do artigo 503 do Código de Processo Civil. ${ }^{206}$

No regime especial, a coisa julgada abrangerá questão que não compõe o objeto litigioso. ${ }^{207}$ Trata-se, assim, de "engenhosa técnica" para que os pronunciamentos que versem sobre questões prejudiciais suscitadas incidentalmente no processo atinjam a autoridade da coisa julgada. ${ }^{208}$

A essência do regime especial trazido pelo Código de Processo Civil de 2015 é a inexigibilidade de postulação pelas partes, mesmo que por ação declaratória incidental, estendendo-se a coisa julgada sobre a questão prejudicial automaticamente. ${ }^{209}$

Interessante o entendimento de Cândido Rangel Dinamarco, quando afirma que: "o resultado final será mais amplo que o objeto do processo, o

\footnotetext{
${ }^{205}$ NERY JUNIOR, Nelson; NERY, Rosa Maria de Andrade. Código de Processo Civil Comentado. $16^{a}$ ed. São Paulo: Revista dos Tribunais, 2016. p. 712.

${ }^{206}$ DIDIER JÚNIOR, Fredie; BRAGA, Paula Sarno; OLIVEIRA, Rafael Alexandria de. Op. cit. p. 615.

${ }^{207}$ Ibid. p. 613.

${ }^{208}$ DINAMARCO, Cândido Rangel. Instituições de direito processual civil. v. 3. $7^{\mathrm{a}}$ ed. São Paulo: Malheiros, 2017. p. 378.

${ }^{209}$ Ibid. p.379.
} 
que constitui uma mitigação da regra da correlação entre a decisão e a demanda, imposta do artigo 492 do Código de Processo Civil ${ }^{210 " .211}$

\author{
Salienta o nobre processualista:
}

\begin{abstract}
"Essa técnica remete-nos à teoria dos efeitos secundários da sentença ou dos atos jurídicos em geral. Todos eles são efeitos exteriores agregados por lei a um ato voluntário, produzidos automaticamente por determinação legal e independentemente de qualquer postura volitiva do agente. Exemplo emblemático é a sentença penal condenatória, dotada por lei de eficácia declaratória da obrigação do condenado a ressarcir os danos causados pelo crime e valendo também como título executivo para a execução civil - efeitos que ela terá sem que a seu respeito o juiz criminal emita qualquer pronunciamento ou sequer cogite deles (supra nn. 1.077 e 1.089). Do mesmo modo, quando presentes os requisitos indicados no art. 503, $\S 1^{\circ}$, do Código de Processo Civil o pronunciamento judicial incidenter tantum a respeito da questão prejudicial valerá como uma decisão tomada principialiter, independentemente de qualquer intenção do juiz, e sobre ele incidirá a autoridade da coisa julgada." 212
\end{abstract}

Alhures, não deve ser taxada como equivocada a existência da coisa julgada especial, pois trata-se de uma legítima opção legislativa com o propósito de proporcionar o maior rendimento possível do processo $^{213}$, através do reconhecimento da estabilidade de uma questão que já fora devidamente debatida pelas partes durante o iter procedimental. ${ }^{214}$

\title{
3.2.2. Requisitos para a formação de coisa julgada especial
}

Para a formação da coisa julgada especial são insuficientes somente os requisitos tradicionais da coisa julgada (decisão de mérito, trânsito em julgado formal e cognição exauriente). ${ }^{215}$

\footnotetext{
${ }^{210} \mathrm{CPC} / 2015$. art. 492. É vedado ao juiz proferir decisão de natureza diversa da pedida, bem como condenar a parte em quantidade superior ou em objeto diverso do que lhe foi demandado.

${ }^{211}$ DINAMARCO, Cândido Rangel. Instituições de direito processual civil. v. 3. $7^{\mathrm{a}}$ ed. São Paulo: Malheiros, 2017. p. 379.

${ }^{212}$ Ibid. p.379/380.

${ }^{213}$ BRASIL. Exposição de Motivos do Código de Processo Civil elaborada pela Comissão de Juristas instituída pelo Ato do Presidente do Senado Federal. p.36. Disponível em: <https://www2.senado.leg.br/bdsf/bitstream/handle/id/512422/001041135.pdf> Acesso em: 10 mai. 2019.

${ }^{214}$ DIDIER JÚNIOR, Fredie; BRAGA, Paula Sarno; OLIVEIRA, Rafael Alexandria de. Op. cit. p. 614.

${ }^{215}$ MENEZES, Lucas. A coisa julgada e as questões incidentais no novo código de processo civil. In: Coisa julgada e outras estabilidades processuais. DIDIER JUNIOR, Fredie; CABRAL, Antônio do Passo (coord.). Salvador: Juspodvim, 2018. p. 236.
} 
À luz do novo codex processual civil, os pressupostos para a formação da coisa julgada sobre questão prejudicial são indispensáveis e cumulativos. ${ }^{216}$ São eles: (i) expressa decisão da questão prejudicial (§ $1^{\circ} \mathrm{do}$ art. 503, CPC); (ii) dependência de julgamento do mérito da decisão da solução da questão prejudicial (inciso I do $\S 1^{\circ}$ do artigo 503, CPC); (iii) existência de contraditório prévio e efetivo (inciso II do $\S 1^{\circ}$ do art. 503, CPC); (iv) competência absoluta do juízo para decidir a referida questão como principal (inciso III do $\S 1^{\circ}$ do art. 503, CPC) e; (v) ausência de restrições probatórias ou cognitivas ( $\left(2^{\circ}\right.$ do art. 503, CPC).

Tais requisitos se assemelham ao que o direito norte-americano exige para a formação do issue preclusion, ou colateral estoppel. ${ }^{217}$ De maneira en passant, pode-se dizer que para a família do commom law, a coisa julgada é vista de duas forma: claim preclusion, que é a proibição da mesma demanda ser novamente decidida e o collateral estoppel, que impede que a decisão sobre questão decida incidenter tantum seja rediscutida. ${ }^{218}$

As questões são atingidas pelo collateral estoppel quando (i) feito um debate prévio; (ii) há decisão expressa pelo órgão julgador; e (iii) a questão for uma razão necessária a decisão da causa. Este instituto é baseado no princípio da boa-fé, no sentido em que as partes devem respeitar opiniões prévias, de forma a não as alterar em feitos posteriores. ${ }^{219}$

\subsubsection{Questão prejudicial expressa e incidentalmente decidida}

\footnotetext{
${ }^{216}$ Enunciado 313 do Fórum Permanente de Processualistas Civis: "São cumulativos os pressupostos previstos nos $\$ 1^{\circ}$ e seus incisos, observado o $\$ 2^{\circ}$ do art. 503."

${ }^{217}$ MEDINA, José Miguel Garcia. Novo Código de Processo Civil comentado: Com remição e notas comparativas ao CPC/73. $5^{\text {a }}$ ed. São Paulo: Revista dos Tribunais, 2017. p. 827.

218 SAMPIETRO, Luiz Roberto Hijo. Primeiras reflexões sobre a possibilidade de a coisa julgada atingir questões prejudiciais no Novo Código de Processo Civil. Revista de Processo. vol. 253. ano 41. São Paulo: Revista dos Tribunais, mar. 2016. p. 194/195.

${ }^{219}$ WAMBIER, Teresa Arruda Alvim. O que é abrangido pela coisa julgada no Direito Processual Civil Brasileiro: a Norma Vigente e as perspectivas de mudança. Revista de Processo. ano 39. v. 230. São Paulo: Revista dos Tribunais, abr. 2014. p. 83.
} 
Como já exposto, as questões prejudiciais são aquelas que representam um antecedente lógico necessário a decisão da questão principal.

Neste ponto, o questionamento que se faz é qual é o "conteúdo" da questão prejudicial que se torna apta a formar coisa julgada. Para Didier Junior a questão prejudicial referida no $\S 1^{\circ}$ do artigo 503 pode dizer respeito à relação jurídica e à autenticidade/falsidade de documento, isto é, questões capazes de figurar como objeto de ação declaratória nos moldes do art. 19, incisos I e II do Código de Processo Civil. ${ }^{220}$

Alguns estudiosos do processo, entendem que não há formação de coisa julgada automática sobre autenticidade/falsidade de documento. Nestas hipóteses, deve a arguição ser objeto expresso de ação declaratória, em respeito ao previsto no artigo 430, caput e parágrafo único ${ }^{221}$ e $433^{222}$ do Código de Processo Civil. ${ }^{223}$

Ressalta-se, ainda, que a coisa julgada recaíra sobre questões jurídicas e não sobre questões fáticas ${ }^{224}$ (capítulo II.iii deste projeto de monografia e artigo 504, II, CPC). De forma exemplificativa, pode-se dizer que em uma

${ }^{220} \mathrm{CPC} / 2015$ Art. 19. O interesse do autor pode limitar-se à declaração:

I - da existência, da inexistência ou do modo de ser de uma relação jurídica;

II - da autenticidade ou da falsidade de documento.

${ }^{221} \mathrm{CPC} / 2015$. 430. A falsidade deve ser suscitada na contestação, na réplica ou no prazo de 15 (quinze) dias, contado a partir da intimação da juntada do documento aos autos.

Parágrafo único. Uma vez arguida, a falsidade será resolvida como questão incidental, salvo se a parte requerer que o juiz a decida como questão principal, nos termos do inciso II do art. 19 .

${ }^{222}$ CPC/2015. Art. 433. A declaração sobre a falsidade do documento, quando suscitada como questão principal, constará da parte dispositiva da sentença e sobre ela incidirá também a autoridade da coisa julgada.

${ }^{223}$ REDONDO. Bruno Garcia. Questões prejudiciais e limites objetivos da coisa julgada no novo CPC. Revista do Processo. vol. 248. ano 40, p. 43 - 67. São Paulo: Revista Tribunais, out. 2016. p. 50.

${ }^{224}$ Importante ressaltar, nesse ponto, que o artigo 123 do Código de Processo Civil enuncia que transitada em julgado a sentença em processo, no qual ocorreu intervenção de terceiro por assistência, não poderá o assistente discutir a justiça da decisão em processo posterior. Por "justiça da decisão" entende-se os fundamentos fáticos e jurídicos que motivam a sentença. Neste caso, tanto questões "fáticas" quanto "jurídicas" localizadas topograficamente na fundamentação da decisão não poderão ser rediscutidas. A doutrina esclarece, contudo, que essa limitação "tangência a coisa julgada, mas não se confunde com ela”. Parte dos processualistas a chamam de eficácia da intervenção ou eficácia da assistência. DIDIER JÚNIOR, Fredie. Curso de Direito Processual Civil: Introdução ao Direito Processual Civil, Parte Geral e Processo de Conhecimento. v. 1. 18 ed. Salvador: Juspodivm, 2016. p. 495; SAMPAIO, Marcos Vinicius de Abreu. Da intervenção de Terceiros. In: WAMBIER, Teresa Arruda Alvim et al (coord.). Breves comentários ao Novo Código de Processo Civil. São Paulo: Revista dos Tribunais, 2015. p. 407. 
ação, em que se pleiteia o cumprimento de uma obrigação pactuada em um contrato, a eventual invalidade deste instrumento contratual resolvida incidentalmente pelo juízo pode ser acobertado pela coisa julgada, mas o fato deste vício decorrer de coação, por exemplo, não se torna imutável. ${ }^{225}$

De acordo com o disposto no parágrafo $1^{\circ}$ do artigo 503 do diploma processual, a extensão da coisa julgada a questão prejudicial só ocorre se esta for decidida "expressa" e "incidentalmente" no processo.

É evidente que a resolução da questão prejudicial deve aparecer de forma expressa, precisa e fundamentada e não como uma "manifestação inconclusiva" ${ }^{226}$. A resolução da questão prejudicial deve necessariamente atender aos mesmos preceitos legais exigidos à apreciação da questão principal, como a certeza da decisão (§ único do artigo 492, $\left.\mathrm{CPC}^{227}\right){ }^{228}$

Mesmo que a questão seja discutida pelas partes litigantes durante o processo, se o magistrado não a apreciar, não haverá incidência da coisa julgada. A imutabilidade e indiscutibilidade não poderão atingir decisão que sequer fora proferida. ${ }^{229}$ Por óbvio, essa decisão não deve ser feita por ato jurisdicional autônomo nem antes de ser prolatada a sentença. O importante é que a questão seja verdadeiramente resolvida no corpo sentencial, contando

\footnotetext{
${ }^{225}$ Ramina de Lucca salienta que tal opção legislativa é incompreensível. Para ele: "Se a intenção era otimizar o processo, evitar novas discussões e impedir decisões conflitantes, a imunização das questões fáticas seria muito mais eficiente do que a imunização das questões jurídicas". RAMINA DE LUCCA, Rodrigo. Os limites objetivos da coisa julgada no Novo Código de Processo Civil. Revista do Processo. v. 252. ano 41. p. 79 - 110. São Paulo: Revista dos Tribunais, fev. 2016. p. 100.

${ }^{226}$ MEDINA, José Miguel Garcia. Op. cit. p. 827. Segundo o processualista "p. e., se o juiz afirma que "não ficou provada a validade da cláusula contratual", não se pode inferir, só por isso, que tenha declarado a invalidade da clausula".

${ }^{227} \mathrm{CPC} / 2015$ : Art. 492. É vedado ao juiz proferir decisão de natureza diversa da pedida, bem como condenar a parte em quantidade superior ou em objeto diverso do que lhe foi demandado. Parágrafo único. A decisão deve ser certa, ainda que resolva relação jurídica condicional.

${ }^{228}$ MEDINA, José Miguel Garcia. Op. cit. p. 827.

${ }^{229}$ REDONDO, Bruno Garcia. Questões prejudiciais e limites objetivos da coisa julgada no novo CPC. Revista do Processo. vol. 248. ano 40. p. 43 - 67. São Paulo: Revista Tribunais, out. 2016. p. 51.
} 
com fundamentação capaz de explicar a opção do órgão julgador ${ }^{230}$, nos moldes do artigo 93, IX da Carta Magna.

Além disso, a questão deve ser decidida incidentalmente no processo. A previsão do novel código é fundamental, visto que a prejudicialidade pode se manifestar de forma incidental ou principal. $^{231}$ À manifestação da prejudicialidade como pedido principal, convencionou dar-se o nome de “causa prejudicial” (vide subcapítulo II.iv do trabalho). Por exemplo no caso de cumulação de pedido de investigação da paternidade e de alimentos. Nesta circunstância, a formação da coisa julgada seguirá o regramento tradicional previsto no caput do artigo 503 do Código de Processo Civil. ${ }^{232}$

A manifestação da prejudicialidade de forma incidental é objeto do dispositivo em apreço (artigo 503, $\S 1^{\circ}, \mathrm{CPC}$ ). As questões que são resolvidas no decorrer do processo e não formam o “objeto litigioso", como é o caso da filiação em uma demanda de alimentos, podem formar coisa julgada.

\subsubsection{Dependência do julgamento do mérito}

O segundo requisito, firmado no inciso $\mathrm{I}$ do $\S 1^{\mathrm{o}}$ do artigo 503 do Código de Processo Civil, é a dependência para o julgamento da questão principal. Assim, para lograr a autoridade da coisa julgada, a questão prejudicial deve necessariamente constituir fundamento necessário a decisão da questão principal. ${ }^{233}$

Esse pressuposto parece tautológico, se considerado que a relação de dependência entre a questão prejudicial e a questão principal é intrínseca à

\footnotetext{
${ }^{230}$ MARINONI. Luiz Guilherme. Coisa julgada sobre questão, inclusive em benefício de terceiro. Revista do Processo. vol. 259. ano 41. p. 91-116. São Paulo: Revista do Tribunal, set. 2016. p. 109. ${ }^{231}$ DIDIER JÚNIOR, Fredie; BRAGA, Paula Sarno; OLIVEIRA, Rafael Alexandria de. Op. cit. p. 612.

${ }^{232}$ Ibid. p. 621

${ }^{233}$ MARIONONI, Luiz Guilherme; ARENHART, Sergio Cruz; MITIDIERO, Daniel. Código de Processo Civil Comentado. $3^{\mathrm{a}}$ ed. São Paulo: Revista dos Tribunais, 2017. p. 617.
} 
prejudicialidade. Com efeito, a doutrina aponta dois aspectos consideráveis para dar utilidade a tal dispositivo. ${ }^{234}$

O primeiro aspecto é destinado aos adeptos ao entendimento de que a questão prejudicial e a questão preliminar não se diferem por sua natureza, admitindo-se questões prejudiciais de mérito e questões prejudiciais processuais. Para tais estudiosos, esse dispositivo é fundamental para afastar da incidência da coisa julgada a questão prejudicial processual. ${ }^{235}$

O segundo aspecto é o distanciamento da coisa julgada dos elementos extraídos do obiter dictium ${ }^{236}$, ou seja, daqueles argumentos secundários ou acessórios utilizados como mera retórica jurídica, que não tenham qualquer influência fundamental para o deslinde do objeto principal do litígio. ${ }^{237}$

Diante do exposto, se conclui que as questões resolvidas como obter dictium ou de natureza processual não são aptas a formação da coisa julgada. ${ }^{238}$

\subsubsection{Existência de contraditório prévio e efetivo}

O terceiro requisito, consubstanciado no inciso II do $\S 1^{\circ}$ do artigo 503 do Código de Processo Civil, consiste na existência de contraditório prévio e efetivo.

O princípio do contraditório afigura-se em duas garantias: (i) de participação na formação do resultado do julgamento e (ii) de não surpresa. À luz do modelo constitucional, a decisão final deve ser resultado de um acirrado debate entre os sujeitos processuais, e não "fruto do solipsismo do juiz”. Neste sentido, o próprio artigo 10 do Código de Processo Civil narra

\footnotetext{
${ }^{234}$ NEVES, Daniel Amorim Assumpção. Novo Código de Processo Civil Comentado. $3^{\mathrm{a}}$ ed. Salvador: Juspodivm, 2018. p. 885.

${ }^{235}$ Ibid. p. 886

${ }^{236}$ Ibid. p. 886.

${ }^{237}$ DIDIER JÚNIOR, Fredie; BRAGA, Paula Sarno; OLIVEIRA, Rafael Alexandria de. op. cit. p. 516.

${ }^{238}$ DONIZETTI, Epídio. Novo Código de Processo Civil Comentado. $3^{\text {a }}$ ed. São Paulo: Atlas, 2018. p. 437.
} 
que o magistrado não pode decidir acerca de qualquer matéria, mesmo aquelas cognoscíveis de ofício, sem a prévia manifestação das partes. ${ }^{239}$

O contraditório efetivo desponta como verdadeira garantia para que as partes tenham a oportunidade de participar do debate e influenciar na decisão, permitindo-se, assim, que convençam o julgador sobre o cabimento de suas colocações. ${ }^{240}$ Desta forma, essa garantia objetiva a legitimação do poder estatal do processo, que depende da efetiva possibilidade de participação das partes possivelmente afetadas pela jurisdição. ${ }^{241}$

Nesse passo, o legislador, ao substituir o pedido expresso declaratório pela existência concreta de contraditório, privilegiou a dialética processual como mecanismo de construção da decisão final do órgão julgador em conjunto com as partes. ${ }^{242}$

Com efeito, o princípio do contraditório é âmago de qualquer sistema de estabilidades. Isso porque, havendo contraditório concreto e efetivo entre os sujeitos participantes do processo, aquela discussão não precisará ser reproduzida em outro feito. ${ }^{243}$

Comparativamente ao regime da coisa julgada tradicional, pode-se identificar uma postura excessivamente protetiva do legislador quanto ao contraditório na discussão de questões prejudiciais ${ }^{244}$, visto que há impedimento da formação de coisa julgada sobre a questão incidentalmente resolvida nos casos de revelia.

\footnotetext{
${ }^{239}$ CÂMARA, Alexandre Freitas. O novo Processo Civil Brasileiro. $2^{\text {a }}$ ed. São Paulo: Atlas, 2016. p. $10 / 11$

${ }^{240}$ DIDIER JÚNIOR, Fredie; BRAGA, Paula Sarno; OLIVEIRA, Rafael Alexandria de. Op. cit. p. 616.

${ }^{241}$ MARINONI, Luiz Guilherme. Coisa julgada sobre questão, inclusive em beneficio de terceiro. Revista do Processo. vol. 259. ano 41. p. 97-116. São Paulo: Revista dos Tribunais, set. 2016. 102. ${ }^{242}$ REICHELT. Luiz Alberto. Decisão sobre questões prejudiciais de mérito e direito fundamental à intangibilidade da coisa julgada material no novo Código de Processo Civil. Revista de processo. vol. 259. ano 41. p. 81-96. São Paulo: Revista dos Tribunais, set. 2016. p. 90.

${ }^{243}$ CABRAL. Antônio Passo. Coisa julgada. In: WAMBIER, Teresa Arruda Alvim et al (coord.). Breves comentários ao Novo Código de Processo Civil. São Paulo: Revista dos Tribunais, 2015. p. 1292.

${ }^{244}$ Ibid. p. 1292.
} 
De acordo com Didier, a preocupação exacerbada do legislador se justifica, pois o debate acerca da questão incidental teoricamente teria sido menos consistente e intenso que aquele travado a respeito da questão principal. ${ }^{245}$

Há quem discorde de tal cautela legislativa. Isso porque, o efeito material da revelia é a presunção de veracidade das alegações formuladas pelo autor (art. 344, CPC). Ocorre que essa presunção é iuris tantum, admitindo prova em contrário, que poderá ser produzida no momento em que o réu ingressa no processo (art. 349, CPC), o que possibilita, portanto, a efetivação do contraditório, mesmo que de forma tardia. ${ }^{246}$ Assim, uma parte da doutrina defende que só há restrição de formação da coisa julgada nos casos em que réu revel deixa de comparecer ao processo. ${ }^{247}$

Aliás, uma questão interessante é que alguns processualistas, como Talamini, sustentam que mesmo a questão não seja "efetivamente" debatida, o requisito estaria preenchido no momento, em que é concedida às partes a oportunidade de instrução probatória e jurídica, uma vez que há disponibilidade de contraditório. ${ }^{248}$

Defende-se, ainda, que a oportunidade de manifestação das partes deve ser uma preocupação do juiz, que também deve contribuir para a delimitação da coisa julgada - princípio da cooperação. Assim, quando o magistrado vislumbrar uma questão prejudicial a ser solucionada, tem o

\footnotetext{
${ }^{245}$ DIDIER JÚNIOR, Fredie; BRAGA, Paula Sarno; OLIVEIRA, Rafael Alexandria de. Op. cit. p. 618.

${ }^{246}$ CÂMARA, Alexandre Freitas. Op. cit. p. 207.

247 NEVES, Daniel Amorim Assumpção. Novo Código de Processo Civil Comentado. $3^{\mathrm{a}}$ ed. Salvador: Juspodivm, 2018. p. 886. Da mesma forma Redondo afirma: “(...) não haverá formação de coisa julgada sobre ponto prejudicial somente quando se tratar de uma revelia "qualificada", isto é, o réu for revel e, além disso, tiver havido a produção do efeito material da revelia e o réu não tiver conseguido, por meio de objeção antes da sentença, controverter, substancialmente, o ponto prejudicial. Somente nessa estrita hipótese é que não terá havido contraditório prévio e efetivo, caso em que não poderá se formar coisa julgada sobre tal ponto." REDONDO. Bruno Garcia. Questões prejudiciais e limites objetivos da coisa julgada no novo CPC. Revista do Processo. vol. 248. ano 40. p. 43 - 67. São Paulo: Revista Tribunais, out. 2016. p. 52.

${ }^{248}$ TALAMINI, Eduardo. Questões prejudiciais e coisa julgada. São Paulo, 2016. Disponível em $<$ https://www.migalhas.com.br/dePeso/16,MI235860,101048-

Questoes+prejudiciais+e+coisa+julgada> Acesso: 10 de ab. de 2019.
} 
dever de indicá-la às partes para que haja um debate prévio, acompanhado da adequada produção probatória. ${ }^{249}$

De forma diversa, há quem diga que havendo previsão expressa sobre possibilidade de questão prévia incidentalmente decidida transitar em julgado, não é obrigação do juiz alertar os litigantes. Essa ausência de obrigatoriedade não impede, contudo, que o magistrado, na decisão de saneamento do processo, faça referência expressa as questões prejudiciais relevantes (artigo 357, II e III, CPC). ${ }^{250}$

Por fim, urge destacar que da exigência de contraditório efetivo, Didier extrai outro requisito fundamental: a legitimidade das partes para a discussão da questão prejudicial ${ }^{251}$. De forma muito elucidativa o autor cita o exemplo da institucionalidade de uma lei suscitada como questão prejudicial em um processo. Evidente que qualquer pessoa pode discutir a constitucionalidade de uma lei, em controle difuso, mas somente os legitimados elencados no artigo 103 da Constituição Federal podem alegá-la em controle concentrado. Assim, mesmo que o próprio Supremo Tribunal Federal, órgão jurisdicional competente, decida a matéria, não haverá o contraditório efetivo, visto que não há a participação dos legitimados.

Neste mesmo sentido, os litisconsortes necessários devem participar do processo para concretização do contraditório ${ }^{252}$, nos moldes do enunciado 638 do Fórum Permanente de Processualistas civis, que dispõe que:

\footnotetext{
${ }^{249}$ MARINONI, Luiz Guilherme; ARENHART, Sérgio Cruz; MITIDIERO, Daniel. Novo Curso de Processo Civil: Tutela de direitos mediante procedimento comum. v. 2. $2^{\mathrm{a}}$ edição. São Paulo: Revista dos Tribunais, 2015. p. 634. Também TALAMINI, Eduardo. Questões prejudiciais e coisa julgada. São Paulo, 2016. Disponível em <https://www.migalhas.com.br/dePeso/16,MI235860,101048Questoes+prejudiciais+e+coisa+julgada> Acesso: 10 de ab. de 2019.

${ }^{250}$ REDONDO. Bruno Garcia. Questões prejudiciais e limites objetivos da coisa julgada no novo CPC. Revista do Processo. vol. 248. ano 40. p. 43 - 67. São Paulo: Revista Tribunais, out. 2016. p. $56 / 57$.

${ }^{251}$ DIDIER JÚNIOR, Fredie; BRAGA, Paula Sarno; OLIVEIRA, Rafael Alexandria de. Op. cit. p. 617. Dinamarco também adiciona como requisito da formação de coisa julgada sobre questão incidental a legitimidade passiva e ativa das partes para litigar em juízo acerca da questão prejudicial, nos moldes do artigo 18 do Código de Processo Civil. DINAMARCO, Cândido Rangel. Instituições de direito processual civil. v. 3. $7^{\mathrm{a}}$ ed. São Paulo: Malheiros, 2017. p. 378/379

${ }^{252}$ DIDIER JÚNIOR, Fredie; BRAGA, Paula Sarno; OLIVEIRA, Rafael Alexandria de. Op. cit. p. 618.
} 
“A formação de coisa julgada sobre questão prejudicial incidental, cuja resolução como principal exigiria a formação de litisconsórcio necessário unitário, pressupõe contraditório efetivo por todos os legitimados, observada a parte final do art. 506."253

\subsubsection{Competência absoluta}

De acordo com o inciso III do $\S 1^{\circ}$ do artigo 503 do Código de Processo Civil, também é requisito para a formação da coisa julgada especial a competência absoluta do juízo ratione personae e ratione materiae para resolver a questão prejudicial de forma principal.

Há hipóteses em que o órgão julgador apenas tem competência para analisar a questão de forma incidental, e não principal. É o caso de um juízo federal conhecer da inconstitucionalidade de uma norma, no exercício do controle difuso. É cediço que qualquer órgão jurisdicional pode - como também deve - analisar a constitucionalidade nas normas sob judice, mas a matéria só pode ser julgada como questão principal pelo Supremo Tribunal Federal, em controle concentrado. ${ }^{254}$

Também é o caso de um processo previdenciário tramitando na Justiça Federal, onde se discuta de forma prejudicial uma relação de família. Eventual pronunciamento do magistrado federal versado sobre a questão incidental não terá o condão de formar coisa julgada, em razão de sua incompetência. ${ }^{255}$

Outro exemplo é uma ação trabalhista ajuíza por uma empregada doméstica em face de seus empregadores, visando condenação solidária, na qual se discuta a união estável dos réus. Por óbvio, o reconhecimento pelo

\footnotetext{
${ }^{253}$ FÓRUM PERMENTE DE PROCESSUALISTAS CIVIL (FPPC). Enunciados do Fórum Permanente de Processualistas Civis. Disponível em: <https://institutodc.com.br/wpcontent/uploads/2017/06/FPPC-Carta-de-Florianopolis.pdf> Acesso em: 10 mai. 2019.

${ }^{254}$ DIDIER JÚNIOR, Fredie; BRAGA, Paula Sarno; OLIVEIRA, Rafael Alexandria de. op. cit. p. 619.

${ }^{255}$ Ibid. p. 619.
} 
juízo trabalhista da relação de companheirismo não forma coisa julgada material. ${ }^{256}$

Interessante destacar que o requisito da competência deve ser analisado levando-se em conta o juízo de primeiro grau de jurisdição. Isso porque, há a possibilidade de o órgão recursal ter competência mais ampla do que os órgãos de primeiro grau. No Tribunal de Justiça do Rio de Janeiro, as Câmaras Cíveis são competentes para a julgamento das mais diversas matérias, excepcionando-se as criminais e as relações de consumo. Desta forma, pode o primeiro grau ser composto por órgãos de diferentes competências em relação a matéria (exemplo fazendária e família) e o segundo grau abranger todas elas. Porém, essa amplitude do tribunal recursal não é relevante para a determinação da dimensão da coisa julgada. ${ }^{257}$

Ressalta-se, por fim, a importância de tal pressuposto, uma vez que se não fosse assim estabelecido, a questão efetivamente debatida pelas partes, mesmo que resolvida por órgão incompetente, poderia ser atingir a estabilidade de coisa julgada. ${ }^{258}$

\subsubsection{Ausência de restrições probatórias ou cognitivas}

O último requisito legal está previsto no $§ 2^{\circ}$ do artigo 503 do Código de Processo Civil, segundo o qual não se aplica a extensão da coisa julgada à questão prejudicial se houver restrições probatórias ou limitações à cognição que impeçam o aprofundamento da análise da questão prejudicial.

\footnotetext{
256 NEVES. Daniel Amorim Assumpção. Novo Código de Processo Civil Comentado. $3^{\mathrm{a}}$ ed. Salvador: Juspodivm, 2018. p. 886.

${ }^{257}$ CÂMARA. Alexandre Freitas. Op. cit. p. 309.

${ }^{258}$ CABRAL, Antonio do Passo. Coisa julgada. In: WAMBIER, Teresa Arruda Alvim et al (coord.). Breves comentários ao Novo Código de Processo Civil. São Paulo: Revista dos Tribunais, 2015. p. 1293.
} 
Na linha do contraditório efetivo, o Código de Processo Civil traz proibições a formação do trânsito em julgado material, em "ambientes desfavoráveis", que estreitam a extensão plena do direito probatório. ${ }^{259}$

As restrições probatórias são características em procedimentos sumários documentais, como o mandado de segurança, em que a prova é préconstituída e como nos Juizados Especiais Cíveis, em que é possível arrolar apenas três testemunhas para cada parte (artigo 34 da Lei 9.099/1995 ${ }^{260}$ ) e é descabida perícia complexa (art. 35 da Lei 9.099/1995261).262

As limitações à cognição podem aparecer em sua "profundidade" (tutela provisória) ou em sua "extensão" (ação de desapropriação, consignatória e de inventários). ${ }^{263}$

Além disso, devido a salvaguarda concedida pelo novel diploma processual à autonomia da vontade das partes, essas restrições probatórias ou limitações cognitivas podem resultar do acordo entre as partes em um negócio jurídico processual (artigo 190 do Código de Processo Civil). ${ }^{264}$

De resto, o indeferimento de provas pelo judiciário em decisões fundamentadas, por serem desnecessárias ou meramente protelatórias (artigo 370, caput e parágrafo único, $\mathrm{CPC}$ ), não é tida, em regra, como restrição probatória. Isso porque, o indeferimento de provas irrelevantes não obsta que o juiz decida a causa com base em cognição exauriente. ${ }^{265}$

\footnotetext{
${ }^{259}$ MARINONI, Luiz Guilherme; ARENHART, Sérgio Cruz; MITIDIERO, Daniel. Novo Curso de Processo Civil: Tutela de direitos mediante procedimento comum. v. 2. $2^{\text {a }}$ ed. São Paulo: Revista dos Tribunais, 2015. p. 634. d

${ }^{260}$ BRASIL. Lei n. 9.099, de 26 de setembro de 1995. Brasília, 26 set. 1995. Disponível em:

<http://www.planalto.gov.br/ccivil_03/Leis/L9099.htm> Acesso: 14 mai. 2019.

${ }^{261}$ Ibid.

${ }^{262}$ REDONDO. Bruno Garcia. Questões prejudiciais e limites objetivos da coisa julgada no novo CPC. Revista do Processo. vol. 248. ano 40. p. 43 - 67. São Paulo: Revista Tribunais, out. 2016. p. 54.

${ }^{263}$ NEVES, Daniel Amorim Assumpção. Novo Código de Processo Civil Comentado. $3^{\mathrm{a}}$ ed. Salvador: Juspodivm, 2018. p. 886.

${ }^{264}$ DIDIER JUNIOR. Fredie. Coisa julgada. In: WAMBIER, Teresa Arruda Alvim et al (coord.). Breves comentários ao Novo Código de Processo Civil. São Paulo: Revista dos Tribunais, 2015. p. 769.

${ }^{265}$ MATTOS. Sérgio. Resolução de questão prejudicial e coisa julgada: primeiras linhas sobre o art. $503, \S \S 1^{\circ}$ e $2^{\circ}$, do CPC/2015. In: Coisa Julgada e outras estabilidades processuais. DIDIER JUNIOR, Fredie; CABRAL, Antônio do Passo. Salvador: Juspodivm, 2018. p. 220.
} 
A proibição da res iudicata nestas hipóteses é muito coerente se considerado que diante do "déficit do contraditório", as mesmas questões podem posteriormente ser objeto de procedimentos mais completos, com uma produção de prova e cognição aperfeiçoadas, o que proporcionará, em alguns casos, uma resposta diferente do judiciário. ${ }^{266}$

Frisa-se, no entanto, que alguns processualistas defendem que a aplicação do $\$ 2^{\circ}$ do artigo 503 do novel diploma processual deve ser feita com parcimônia, sendo observado se nos procedimentos supracitados, de fato, houve "impedimento no aprofundamento da análise da questão prejudicial”.

Pode-se citar o exemplo de um procedimento tramitando em Juizado Especial, em que apesar da limitação ao número de testemunhas e a impossibilidade de prova pericial mais complexa, a questão prejudicial seja resolvida eminentemente com uma prova documental. Assim, tem-se que as limitações probatórias não interfeririam no deslinde da questão incidental, sendo cabível - se preenchidos os requisitos do $\S 1^{\circ}$ do artigo 503, CPC - a extensão a coisa julgada a resolução da referida questão. ${ }^{267}$

\subsubsection{Diferença entre eficácia preclusiva e coisa julgada sobre questão prejudicial}

Uma questão salutar é estabelecer uma diferença entre a coisa julgada sobre questão prejudicial e a eficácia preclusiva da coisa julgada. Ambas incidem sobre os fundamentos da decisão final, mas não se confundem.

O artigo 508 prevê o que a doutrina convencionou chamar de eficácia preclusiva da coisa julgada. Segundo o dispositivo, transitada em julgado a decisão de mérito, todas as alegações e defesas que poderiam ter sido

\footnotetext{
${ }^{266}$ CABRAL, Antonio do Passo. Coisa julgada. In: WAMBIER, Teresa Arruda Alvim et al (coord.). Breves comentários ao Novo Código de Processo Civil. São Paulo: Revista dos Tribunais, 2015. p. 1294.

${ }^{267}$ NEVES, Daniel Amorim Assumpção. Novo Código de Processo Civil Comentado. $3^{\mathrm{a}}$ ed. Salvador: Juspodivm, 2018. p. 887.
} 
formuladas para o acolhimento ou rejeição do pedido reputam-se deduzidas e repelidas. ${ }^{268}$ Isso significa que a coisa julgada faz precluir a possibilidade de as partes suscitarem argumentos que poderiam ter sido suscitados. ${ }^{269}$ Exatamente por esse motivo que, desde o direito romano, se afirma que " $a$ coisa julgada cobre o deduzido e o deduzível, a res deducta e a res deducenda. ${ }^{270}$

A amplitude dessa eficácia preclusiva é muito discutida pela doutrina. A corrente majoritária, formada por Barbosa Moreira, Moniz de Aragão e Mitidiero, entendem que essa eficácia incide apenas sobre argumentos e provas que embasam a causa petendi. A preclusão não atingiria todas as causas de pedir passíveis de fundamentar o pedido deduzido. Desta forma, haveria a possibilidade de interposição de nova ação, contendo o mesmo pedido, mas diferente causa de pedir. ${ }^{271}$ Ora, renovar o pedido com outra causa de pedir é propor demanda diversa. ${ }^{272}$

Há outra corrente, segundo a qual todas as possíveis causas de pedir são atingidas pela eficácia preclusiva da coisa julgada, não apenas os argumentos. ${ }^{273}$

Neste trabalho, adota-se a corrente majoritária.

Logo, conclui-se que a eficácia preclusiva nada mais é que uma aptidão da coisa julgada em evitar que as partes ajuízem nova demanda com a mesma causa de pedir e pedido, mas com argumentos diferentes, os quais

\footnotetext{
${ }^{268}$ BRASIL. Lei n. 13.105, de 16 de março de 2015. Código de Processo Civil. Brasília, 16 mar. 2015. Disponível em: <http://www.planalto.gov.br/ccivil_03/_ato20152018/2015/lei/113105.htm>. Acesso em: 15 abr. 2019.

${ }^{269}$ DIDIER JUNIOR. Fredie. Coisa julgada. In: CABRAL, Antonio do Passo; CRAMER, Ronaldo. Comentários ao Novo Código de Processo Civil. $2^{\mathrm{a}}$ ed. Rio de Janeiro: Forense, 2016. p. 782.

${ }^{270}$ CABRAL, Antonio Passo. Coisa julgada. In: WAMBIER, Teresa Arruda Alvim et al (coord.). Breves comentários ao Novo Código de Processo Civil. São Paulo: Revista dos Tribunais, 2015. p. 1309.

${ }^{271}$ DIDIER JUNIOR. Fredie. . Coisa julgada. In: CABRAL, Antonio do Passo; CRAMER, Ronaldo. Comentários ao Novo Código de Processo Civil. $2^{\mathrm{a}}$ ed. Rio de Janeiro: Forense, 2016. p. 782.

${ }^{272}$ DIDIER JÚNIOR, Fredie; BRAGA, Paula Sarno; OLIVEIRA, Rafael Alexandria de. Op. cit. p. 633.

${ }^{273}$ DIDIER JUNIOR. Fredie. . Coisa julgada. In: CABRAL, Antonio do Passo; CRAMER, Ronaldo. Comentários ao Novo Código de Processo Civil. $2^{\mathrm{a}}$ ed. Rio de Janeiro: Forense, 2016. p. 782.
} 
não tinham sido deduzidos na demanda anterior. Enquanto a coisa julgada sobre questão prejudicial consiste na extensão dos limites objetivos da coisa julgada à questão prejudicial incidental (leia-se questão imprescindível ao julgamento do mérito), que já foi amplamente debatida durante o iter procedimental, impedindo, assim, sua rediscussão perante o judiciário.

\subsubsection{Aspectos relevantes:}

Destaca-se alguns dos diversos aspectos relevantes discutidos em sede doutrinária quanto a aplicação do regime especial.

\subsubsection{Desnecessidade de pedido declaratório expresso pela parte}

De fato, o intuito do legislador na criação desta nova sistemática foi o de ver-se livre de amarras procedimentais, possibilitando que a coisa julgada atinente à questão prejudicial fosse formada de forma automática, do mesmo modo da coisa julgada tradicional.

\section{Como afirma Didier Junior:}

"A coisa julgada em qualquer dos seus regimes jurídicos, é efeito que decorre automaticamente da lei, não depende de um "dizer" do órgão julgador ("faça-se coisa julgada") ou de pedido da parte ("pede-se que essa decisão se torne indiscutível pela coisa julgada")." ${ }^{274}$

Neste sentido, o enunciado 165 do Fórum Permanentes de Processualistas Civis é certeiro em dispor que "a coisa julgada da decisão da questão prejudicial independe de pedido expresso da parte, bastando para que ocorra o preenchimento dos requisitos legais. ${ }^{2} 275$

\footnotetext{
${ }^{274}$ DIDIER JUNIOR, Fredie. Coisa julgada. In: CABRAL, Antonio do Passo; CRAMER, Ronaldo. Comentários ao Novo Código de Processo Civil. $2^{\mathrm{a}}$ ed. Rio de Janeiro: Forense, 2016. p. 766.

275 FÓRUM PERMENTE DE PROCESSUALISTAS CIVIL (FPPC). Enunciados do Fórum Permanente de Processualistas Civis. Disponível em: <https://institutodc.com.br/wpcontent/uploads/2017/06/FPPC-Carta-de-Florianopolis.pdf> Acesso em: 10 mai. 2019.
} 


\subsubsection{Sobrevivência da ação declaratória incidental}

Com o regramento do artigo 503 do novo código, a propositura da ação declaratória incidental parece esvaziar-se de utilidade prática, deixando de ser a ferramenta fundamental à expansão da coisa julgada sobre questão prejudicial. ${ }^{276}$

Neste interim, o questionamento que se faz é se a ação declaratória incidental subsiste no nosso ordenamento e se eventualmente proposta, seria inadmita ou rejeitada liminarmente (artigo 330, III, CPC), em razão da ausência de interesse processual. ${ }^{277}$

Ora, em um ordenamento em que se privilegia o acesso à justiça e a inafastabilidade do judiciário (art.5, XXXV, CF), devem ser admitidas prioritariamente demandas das mais diversas. Neste sentido, os artigos $19 \mathrm{e}$ 20 do Código de Processo Civil reconhecem a proposição de ações declaratórias. ${ }^{278}$ Desta forma, em que pese a ausência de previsão legal a respeito da ação declaratória incidental, não há nenhum óbice a sua proposição. ${ }^{279} \mathrm{Na}$ verdade, a postulação de tal ação pode ser benéfica para as partes, por lhes proporcionar maior convicção do alcance da coisa julgada.

Desta forma, tendo a parte interesse em ver a questão prejudicial decidida como principal, poderá intentar a ação declaratória incidental com base no artigo 19, I do CPC e do enunciado 111 do Fórum Permanente dos Processualistas Civis. ${ }^{280}$

Destaca-se que haverá conexão da demanda principal com a demanda declaratória, o que ensejará a reunião das causas, nos moldes do artigo 55 do

\footnotetext{
${ }^{276}$ CABRAL, Antonio Passo. Coisa julgada. In: WAMBIER, Teresa Arruda Alvim et al (coord.). Breves comentários ao Novo Código de Processo Civil. São Paulo: Revista dos Tribunais, 2015. p. 1294.

${ }^{277}$ Ibid. p. 1296.

${ }^{278}$ Ibid. p. 1294.

${ }^{279}$ MEDINA, José Miguel Garcia. Op. cit. p. 829.

${ }^{280}$ 111. (arts. 19, 329, II, 503, § $1^{\circ}$ ) Persiste o interesse no ajuizamento de ação declaratória quanto à questão prejudicial incidental. (Grupo: Coisa Julgada, Ação Rescisória e Sentença)
} 
Código de Processo Civil. ${ }^{281}$ Neste sentido, o enunciado 35 da I Jornada de Direito Processual Civil do Conselho da Justiça Federal assim dispõe:

"Considerando os princípios do acesso à justiça e da segurança jurídica, persiste o interesse de agir na propositura de ação declaratória a respeito da questão prejudicial incidental, a ser distribuída por dependência da ação preexistente, inexistindo litispendência entre ambas as demandas (arts. 329 e 503, $\S 1^{\circ}$, do CPC). ${ }^{282}$

\subsubsection{Desnecessidade de inserção no dispositivo da sentença}

A questão prejudicial consiste em um preceito lógico essencial ao deslinde da questão principal, de forma que, teoricamente, ocuparia espaço na parte da fundamentação da sentença. Contudo, a doutrina é vacilante quanto à (in)exigibilidade da inserção da resolução da questão prejudicial na parte dispositiva do pronunciamento judicial.

Segundo Antônio do Passo Cabral, para que a coisa julgada cubra a prejudicialidade exaustivamente debatida e resolvida basta o preenchimento dos requisitos legais, "ainda que topograficamente posicionada no corpo da fundamentação." 283

Na mesma linha, Assumpção Neves afirma:

"Não me oponho à opção do legislador de estender a autoridade da coisa julgada à decisão da questão prejudicial. Mas desconsiderar que ela faça parte dos motivos da decisão é ficção jurídica com a qual não estou disposto a conviver.”

O entendimento consignado no enunciado 438 do Fórum Permanente de Processualistas Civis é no mesmo sentido: "É desnecessário que a

\footnotetext{
${ }^{281}$ DIDIER JÚNIOR, Fredie; BRAGA, Paula Sarno; OLIVEIRA, Rafael Alexandria de. op. cit. p. 622.

${ }^{282}$ Enunciados aprovados na I Jornada de Direito Processual Civil do Conselho da Justiça Federal. ago. 2017. Disponível em: <https://flaviotartuce.jusbrasil.com.br/noticias/495129671/enunciadosaprovados-na-i-jornada-de-direito-processual-civil-do-conselho-da-justica-federal-agosto-de2017> Acesso em: 20 de mai. 2019.

${ }^{283}$ CABRAL, Antonio do Passo. Coisa julgada. In: WAMBIER, Teresa Arruda Alvim et al (coord.). Breves comentários ao Novo Código de Processo Civil. São Paulo: Revista dos Tribunais, 2015. p. 1294.
} 
resolução expressa da questão prejudicial incidental esteja no dispositivo da decisão para ter aptidão de fazer coisa julgada". ${ }^{284}$

Essa configuração não obsta que o juiz, em privilégio ao princípio da cooperação, venha destacar ou reiterar a resolução da questão prejudicial no dispositivo sentencial. Contudo, essa referência consistiria em formalidade facultativa e não requisito indispensável a res iudicata. ${ }^{285}$

De forma diametralmente oposta, Alexandre Freitas Câmara sustenta que em hipótese alguma a fundamentação transitará em julgado (art.504, CPC), de sorte que uma vez apreciada questão prejudicial, apta a formação da coisa julgada, deve o juiz expressamente decidi-la no dispositivo da sentença. Segundo ele, essa exigência afastaria qualquer dúvida das partes acerca dos limites objetivos da coisa julgada, sendo a impugnação possível em sede recursal, caso não preenchidos alguns dos requisitos legais a sua configuração. ${ }^{286}$

Outros doutrinadores conceituadíssimos, como Luiz Guilherme Marinoni, Sérgio Cruz Arenhart e Daniel Mitidiero defendem a necessidade de a resolução da questão prejudicial estar inserida na parte dispositiva da sentença ${ }^{287}$.

\subsubsection{Submissão à remessa necessária}

\footnotetext{
${ }^{284}$ FÓRUM PERMENTE DE PROCESSUALISTAS CIVIL (FPPC). Enunciados do Fórum Permanente de Processualistas Civis. Disponível em: <https://institutodc.com.br/wpcontent/uploads/2017/06/FPPC-Carta-de-Florianopolis.pdf> Acesso em: 10 mai. 2019.

${ }^{285}$ REDONDO, Bruno Garcia. Questões prejudiciais e limites objetivos da coisa julgada no novo CPC. Revista do Processo. vol. 248. ano 40. p. 43 - 67. São Paulo: Revista Tribunais, out. 2016. p. $57 / 58$.

${ }^{286}$ CÂMARA, Alexandre Freitas. Op. cit. p. 312.

${ }^{287}$ MARINONI, Luiz Guilherme; ARENHART, Sérgio Cruz; MITIDIERO, Daniel. Novo Curso de Processo Civil. Tutela de direitos mediante procedimento comum. v. 2. $2^{\mathrm{a}}$ ed. São Paulo: Revista dos Tribunais, 2015. p. 633.
} 
Em certos casos, diante da relevância do interesse público, a Lei determina o reexame necessário da decisão pelo tribunal ad quem. ${ }^{288} \mathrm{O}$ artigo 496 do Código de Processo Civil estabelece que a sentença contra a Fazenda Pública está sujeita ao duplo grau de jurisdição, não produzindo efeito senão depois de confirmada pelo tribunal. Trata-se da previsão legal à remessa necessária.

Em que pese o dispositivo se referir à "sentença", a doutrina reconhece que qualquer decisão que tenha aptidão a formar coisa julgada, deve ser submetida a reanalise do segundo grau de jurisdição. ${ }^{289}$

Nesse contexto, há entendimento consolidado pelo enunciado n. 439 do Fórum Permanente de Processualistas Civis quanto à necessidade de remessa necessária para a configuração da coisa julgada especial, senão vejamos:

“439. (art. 503, $\S \S 1^{\circ}$ e $2^{\circ}$ ). Nas causas contra a Fazenda Pública, além do preenchimento dos pressupostos previstos no art. $503, \S \S 1^{\circ}$ e $2^{\circ}$, a coisa julgada sobre a questão prejudicial incidental depende de remessa necessária, quando for o caso." 290

\subsubsection{Impugnação da resolução da questão prejudicial e o interesse recursal}

Da questão prejudicial decidida na sentença caberá apelação (artigo $203, \S 1^{\circ}$ e 1009 do CPC) e da questão decidida em decisão interlocutória, agravo de instrumento (artigo 1015, II, CPC). ${ }^{291}$ Haverá interesse processual de reforma da resolução de questão prejudicial (i) para que a questão

\footnotetext{
${ }^{288}$ ARAÚJO FILHO, Luiz Paulo da Silva. Remessa Necessária. In: CABRAL, Antônio do Passo; CRAMER, Ronaldo. Comentários ao Novo Código de Processo Civil. $2^{\mathrm{a}}$ ed. Rio de Janeiro: Forense, 2016. p. 743.

${ }^{289}$ DIDIER JUNIOR, Fredie. Coisa julgada. In: CABRAL, Antonio do Passo; CRAMER, Ronaldo. Comentários ao Novo Código de Processo Civil. $2^{\mathrm{a}}$ ed. Rio de Janeiro: Forense, 2016. p. 769.

290 FÓRUM PERMENTE DE PROCESSUALISTAS CIVIL (FPPC). Enunciados do Fórum Permanente de Processualistas Civis. Disponível em: <https://institutodc.com.br/wpcontent/uploads/2017/06/FPPC-Carta-de-Florianopolis.pdf > Acesso em: 10 mai. 2019.

${ }^{291}$ MATTOS, Sérgio. Resolução de questão prejudicial e coisa julgada: primeiras linhas sobre o art. $503, \S \S 1^{\circ}$ e $2^{\circ}$, do CPC/2015. In: Coisa Julgada e outras estabilidades processuais. DIDIER JUNIOR, Fredie; CABRAL, Antônio do Passo (coord.). Salvador: Juspodivm, 2018. p. 224.
} 
prejudicial seja decidida pelo tribunal ad quem com força de cosia julgada; e (ii) para evitar a formação a coisa julgada, que lhe é desfavorável. ${ }^{292}$

Neste contexto, salienta Bruno Garcia Redondo que se o recurso interposto impugnar apenas a questão principal, sem se referir a questão prejudicial, ele será parcial (artigo 1.002, CPC), cobrindo de estabilidade da coisa julgada a resolução da questão prejudicial (artigo 1.013, § $1^{\circ}, \mathrm{CPC}$ ). Da mesma forma, tendo o recurso atacado apenas a resolução da questão prejudicial, a decisão a respeito da questão principal passará em julgado materialmente. ${ }^{293}$

Outro ponto interessante a ser ressaltado é que tradicionalmente, a sucumbência está ligada a derrota quanto ao resultado da questão principal. Entretanto, segundo Antônio do Passo Cabral, com a nova sistemática, é possível que a parte, mesmo que vencedora em relação ao pedido principal, se veja prejudicada em virtude da resolução da questão prejudicial incidental. ${ }^{294}$

Portanto, passa a existir interesse jurídico para parte que, embora tenha seu pedido julgado procedente, objetive desfazer a sentença quanto ao pronunciamento acerca da questão prejudicial, que lhe foi desfavorável. ${ }^{295}$

Contudo, a possibilidade de impugnação da questão prejudicial não é a posição unânime. Ramina de Lucca, por exemplo, infirma a coerência lógica de se permitir recursos que busquem a reforma exclusiva de questão

\footnotetext{
292 Ibid. 225.

${ }^{293}$ REDONDO, Bruno Garcia. Questões prejudiciais e limites objetivos da coisa julgada no novo CPC. Revista do Processo. vol. 248. ano 40. p. 43 - 67. São Paulo: Revista Tribunais, out. 2016. p. $60 / 61$.

${ }^{294}$ CABRAL, Antonio do Passo. Coisa julgada. In: WAMBIER, Teresa Arruda Alvim et al (coord.). Breves comentários ao Novo Código de Processo Civil. São Paulo: Revista dos Tribunais, 2015. p. 1294. Ressalta-se que Segundo Redondo: "Essa nova noção sobre ganho e perda, contudo, não deve ser levada em conta para fins da identificação do ônus da sucumbência (ônus da parte vencida de arcar comas despesas processuais e os honorários advocatícios). As regras da sucumbência levam em conta apenas o mérito do processo, isto é, o resultado da solução dada ao pedido principal, à pretensão que foi levada ao Poder Judiciário." REDONDO. Bruno Garcia. Questões prejudiciais e limites objetivos da coisa julgada no novo CPC. Revista do Processo. vol. 248. ano 40. p. 43 - 67. São Paulo: Revista Tribunais, out. 2016. p. 60/61.

295 Ibid. p. 1294.
} 
prejudicial. Para ele, se o intuito do legislador era a efetividade e simplificação do procedimento, isso não será alcançado, visto que será alargado significativamente o numérico de recursos. Afirma que "se a parte quer discutir especificamente a questão prejudicial, então deve incluí-la no mérito do processo, pela via adequada (demandando ou reconvindo) e darlhe status de questão principal." 296

\subsubsection{Controle da coisa julgada relativa à questão prejudicial}

Entende-se que a coisa julgada relativa à questão prejudicial incidental é impugnável pelos mesmos mecanismos da coisa julgada tradicional. Portanto, efetivamente comprovado todos os requisitos para a configuração da res iudicata, pode esta ser impugnada mediante ação rescisória, nos moldes do artigo 966 e seguintes do Código de Processo Civil. ${ }^{297}$

Assim, dispõe o enunciado 338 do Fórum Permanente de Processualistas Civis: "Cabe ação rescisória para desconstituir a coisa julgada formada sobre a resolução expressa da questão prejudicial incidental. $" 298$

Acredita-se que a interposição de ação rescisória será um comportamento muito raro na prática processual, por conta da obrigatoriedade de deposito prévio (artigo 967, II, CPC) e do ônus de comprovar o cumprimento dos requisitos para formação a coisa julgada especial (artigo 503, $\S \S 1^{\circ}$ e $2^{\circ}, \mathrm{CPC}$ ). A tendência é que as partes adotarão o

\footnotetext{
${ }^{296}$ RAMINA DE LUCCA, Rodrigo. Os limites objetivos da coisa julgada no Novo Código de Processo Civil. Revista do Processo. v. 252. ano 41. p. 79 - 110. São Paulo: Revista dos Tribunais, fev. 2016. p. 104.

${ }^{297}$ DIDIER JUNIOR, Fredie. Coisa julgada. In: CABRAL, Antonio do Passo; CRAMER, Ronaldo. Comentários ao Novo Código de Processo Civil. $2^{\mathrm{a}}$ ed. Rio de Janeiro: Forense, 2016. p. 769.

${ }^{298}$ FÓRUM PERMENTE DE PROCESSUALISsTAS CIVIL (FPPC). Enunciados do Fórum Permanente de Processualistas Civis. Disponível em: <https://institutodc.com.br/wpcontent/uploads/2017/06/FPPC-Carta-de-Florianopolis.pdf> Acesso em: 10 mai. 2019.
} 
caminho mais fácil e menos técnico de ajuizamento de nova demanda repropondo a discussão sobre a questão já debatida e resolvida. ${ }^{299}$

\subsubsection{Questão prejudicial em relação a terceiros}

Outro ponto enfrentado pela doutrina é se a questão prejudicial pode afetar terceiros não participantes do processo. É o caso de questão debatida e resolvida, que diga respeito a um conflito concreto em que o terceiro está inserido. ${ }^{300}$ Esse terceiro não é titular dos direitos e obrigações referentes a decisão, mas encontra-se em posição tal, que sua esfera de direitos pode ser afetada. $^{301}$

Pelos mesmos parâmetros abalizados para as questões principais, Marinoni acredita que a decisão de questão incidental pode beneficiar terceiros estranhos ao processo, mas nunca os prejudicar. ${ }^{302}$

Segundo Dinamarco, a princípio, não deveria haver vinculação entre o julgamento da questão prejudicial a terceiros, uma vez que "embora correlatas as situações, ao menos o objeto é diferente em uma e outra". $\mathrm{O}$ processualista prossegue fazendo uma comparação. Diz que o entendimento consolidado pela jurisprudência é que julgado procedente uma ação de investigação de paternidade, os seus efeitos não terão o condão de vincular um outro indivíduo que alegue ser pai daquela criança, não o impedindo desde $\operatorname{logo}$ de se dirigir ao judiciário para requerer o reconhecimento de paternidade - isso porque, haveria cerceamento de defesa. ${ }^{303}$

\footnotetext{
${ }^{299}$ MATTOS, Sérgio. Resolução de questão prejudicial e coisa julgada: primeiras linhas sobre o art. $503, \S \S 1^{\circ}$ e $2^{\circ}$, do CPC/2015. In: Coisa Julgada e outras estabilidades processuais. DIDIER JUNIOR, Fredie; CABRAL, Antônio do Passo (coord.). Salvador: Juspodivm, 2018. p. 226.

${ }^{300}$ MARINONI. Luiz Guilherme. Coisa julgada sobre questão, inclusive em beneficio de terceiro. Revista do Processo. vol.259. ano 41. p. 91-116. São Paulo: Revista do Tribunal, set. 2016. p. 110. ${ }^{301}$ DINAMARCO. Cândido Rangel. Instituições de direito processual civil. v. 3. $7^{\mathrm{a}}$ ed. São Paulo: Malheiros, 2017. p. 388.

${ }^{302}$ MARINONI. Luiz Guilherme. Coisa julgada sobre questão, inclusive em benefício de terceiro. Revista do Processo. vol.259. ano 41. p. 91-116. São Paulo: Revista do Tribunal, set. 2016. p. 112. ${ }^{303}$ DINAMARCO. Cândido Rangel. Instituições de direito processual civil. v. 3. $7^{\mathrm{a}}$ ed. São Paulo: Malheiros, 2017. p. 388.
} 


\subsubsection{Direito transitório}

O artigo 1.054 do Código de Processo Civil excepciona a eficácia imediata das normas processuais civis. ${ }^{304} \mathrm{O}$ novo regime de coisa julgada sobre questão prejudicial será aplicado aos processos que tiverem início após a entrada em vigor do código.

Aos processos anteriores, é aplicável o antigo diploma processual, de forma que a coisa julgada sobre questão prejudicial, dependerá necessariamente da postulação da ação declaratória incidental (art.5 $5^{\circ}, 320$ e 470, CPC/1973). ${ }^{305}$

A regra é louvável, uma vez que a aplicabilidade dos pressupostos previstos no art. 503, parágrafos $1^{\circ}$ e $2^{\circ}$ dependem dos atos praticados durante o processo. Se houvesse aplicação imediata, as partes seriam surpreendidas por consequências que não poderiam prever e, se pudessem, adotariam comportamento diferente. ${ }^{306}$

304 RAMINA DE LUCCA, Rodrigo. Os limites objetivos da coisa julgada no Novo Código de Processo Civil. Revista do Processo. v. 252. ano 41. p. 79 - 110. São Paulo: Revista dos Tribunais, fev. 2016. p. 106.

${ }^{305}$ DIDIER JÚNIOR, Fredie; BRAGA, Paula Sarno; OLIVEIRA, Rafael Alexandria de. Op. cit. p. 623.

${ }^{306}$ RAMINA DE LUCCA, Rodrigo. Os limites objetivos da coisa julgada no Novo Código de Processo Civil. Revista do Processo. v. 252, ano 41. p. 79 - 110. São Paulo: Revista dos Tribunais, fev. 2016. p. 106. 


\section{CONCLUSÃO}

A ideia românica de coisa julgada, estampada no Digesto, consistente na descoberta da verdade - res iudicata pro veritate accipitur - não prevalece no ordenamento jurídico pátrio. Sob a ótica jurídica atual a coisa julgada não se vincula a noção de verdade, nem mesmo presunção da verdade. A coisa julgada constitui apenas uma nobilíssima opção do legislador constitucional de busca da estabilidade das relações sociais. ${ }^{307}$

O legislador poderia ter optado pela certeza ao invés da estabilidade, o que autorizaria a revisão da decisão proferida em determinado feito judicial a qualquer tempo, perpetuando-se, assim, a solução da controvérsia. De fato, essa escolha não seria tão judiciosa, visto que a eternização dos conflitos é vista como uma situação nefasta para a segurança jurídica e para efetiva prestação jurisdicional. Assim, o sistema de estabilidades, mormente o instituto da coisa julgada, pode ser visto como um critério de justiça para processualística civil. ${ }^{308}$

Nesse passo, cabe ressaltar que a possibilidade de acesso ao judiciário perde sua magnitude se considerados os atuais problemas de morosidade e falta de efetividade. Ora, um sistema processual que não oferece aos jurisdicionados o reconhecimento e realizações de seus direitos não se harmoniza com as garantias constitucionais de um Estado Democrático. ${ }^{309}$

A busca pela eliminação dos vícios do sistema vigente impulsionou a edição do recente Código de Processo Civil, promulgado em 2015. A Exposição de Motivos desse novo diploma já enuncia seu potencial de gerar um processo mais justo, célere e simplificado. A simplificação dispõe-se a

\footnotetext{
${ }^{307}$ MARINON, Luiz Guilherme; ARENHART, Sérgio Cruz; MITIDIERO, Daniel. Novo Curso de Processo Civil: Tutela de direitos mediante procedimento comum. v. 2. $2^{\mathrm{a}}$ ed. São Paulo: Revista dos Tribunais, 2015. p. 623.

${ }^{308}$ Ibid. p. 624.

309 BRASIL. Exposição de Motivos do Código de Processo Civil elaborada pela Comissão de Juristas instituída pelo Ato do Presidente do Senado Federal. p. 26-28. Disponível em: <https://www2.senado.leg.br/bdsf/bitstream/handle/id/512422/001041135.pdf> Acesso em: 30 de abr. de 2019.
} 
suscitar a maior coesão e centralização da atenção e do esforço do Estadojuiz ao mérito da causa. ${ }^{310}$

Uma das formas de alcançar estes objetivos foi a adoção de novo regime jurídico acerca da coisa julgada. Muito se discorreu nesta monografia sobre uma das mudanças mais intrigantes trazidas pela referida onda modificadora, a extensão da coisa julgada à questão prejudicial.

As razões especificas para a alteração legislativa são relacionadas à efetivação da jurisdição, ao rendimento e à economia processual. A legitimidade do regime é defendida amplamente pelos processualistas, por assegurar a estabilidade de uma decisão plenamente discutida e analisada. Ora, é incoerente que uma questão já concluída em definitivo em uma ação jurisdicional (mesmo que de forma incidental) possa ser objeto de outro feito. Isso geraria dupla apreciação do poder judiciário, que já se encontra há muito sobrecarregado.

Registra-se que a mudança gerou um burburinho geral dos processualistas, que se prontificarão a se esmiuçar no tema. Além do exame dos dispositivos inseridos no novo Código de Processo Civil, os estudiosos destacaram aspectos assaz relevantes para a correta aplicação do regime especial de coisa julgada.

Porém a pergunta que se faz é: "Será que a implementação deste novo regime amenizará os problemas e gerará maior economia processual?”. A alteração legislativa é sobremaneira recente para que se ofereça uma resposta precisa para este questionamento. Certo é, que, o novo regime está sendo posto à prova pelos nossos tribunais.

Alguns processualistas acreditam, contudo, que a nova sistemática burlaria o princípio do dispositivo, visto que a coisa julgada incidiria sobre

\footnotetext{
310 BRASIL. Exposição de Motivos do Código de Processo Civil elaborada pela Comissão de Juristas instituída pelo Ato do Presidente do Senado Federal. p. 26-28. Disponível em: <https://www2.senado.leg.br/bdsf/bitstream/handle/id/512422/001041135.pdf> Acesso em: $30 \mathrm{de}$ abr. de 2019.
} 
questão que não foi postulada pelas partes ${ }^{311}$. Exatamente este argumento que foi utilizado pelos Senadores Francisco Dornelles e Marconi Perillo quando propostas as infrutíferas emendas 58 e 148 ao Projeto do Novo Código de Processo Civil.

Não apenas isso, alguns defendem que a inovação não traria economia processual, uma vez que a complexidade e o tempo de duração do primeiro processo aumentariam muito. É evidente que mera possibilidade de a coisa julgada incidir sobre questões discutidas no processo, trará maior cautela para as partes, que se empenharam em debater ferrenhamente questões prejudiciais surgidas incidentalmente como se fossem principais. ${ }^{312}$

Para Antônio Gigi, José Maria Rosa Tesheiner e Marília Zanella Prates:

"Ainda que a coisa julgada sobre questões gerasse economia processual, é inaceitável justificar a expansão da coisa julgada sobre as questões prejudiciais somente com base na economia dos custos que um processo gera para o Estado. Tal justificativa apenas demonstra a falência da máquina estatal para providenciar ao cesso à Justiça garantido pela Constituição." 313

Prosseguem os autores, dizendo que tampouco a segurança jurídica será privilegiada com a adoção de tal regramento. Isso porque, a necessidade de segurança não justificaria as dificuldades práticas do regime e o custo de tempo e energia para sua implementação. ${ }^{314}$

Neste projeto de monografia, parece mais acertado adotar um posicionamento mais otimista acerca da novidade legislativa. O regime especial de coisa julgada não foi inserido levianamente no ordenamento.

A nova sistemática é produto de um movimento de insatisfação dos processualistas perante a inefetividade jurisdicional. $\mathrm{O}$ artigo 503 é claro e elucidativo e os requisitos enunciados em seus parágrafos privilegiam os

\footnotetext{
${ }^{311}$ DINAMARCO. Cândido Rangel. Op. cit. p. 378/379.

${ }^{312}$ GIDI, Antonio; TESHEINER, José Maria Rosa; PRATES, Marília Zanella. Limites objetivos da coisa julgada no projeto de Código de Processo Civil. Revista do Processo. v. 194. p.101-138. São Paulo: Revista dos Tribunais, abr. 2011. p. 129.

${ }^{313}$ Ibid. p. 129

${ }^{314}$ Ibid. 135.
} 
princípios processuais e constitucionais da ampla defesa e contraditório. Além disso, a doutrina mostra-se bastante receptiva e seus apontamentos servem para aprimorar ainda mais a inovadora sistemática.

Portanto, o regime tem grande potencial para ser gradativamente aplicado na prática, se respeitado os ditames legais e observados alguns comentários relevantes da doutrina. A expectativa é que ele gere a previsibilidade, a economia e a consistência prometidas. 


\section{BIBLIOGRAFIA}

ALVIM, José Eduardo Carreira. Elementos da teoria geral do processo. $2^{\mathrm{a}}$ ed. Rio de Janeiro: Forense: 1993.

ALVIM, Thereza. Questões prévias e os limites objetivos da coisa julgada. São Paulo: Revista dos Tribunais, 1977.

ARAÚJO FILHO, Luiz Paulo da Silva. Remessa necessária. In: CABRAL, Antônio do Passo; CRAMER, Ronaldo. Comentários ao Novo Código de Processo Civil. $2^{\mathrm{a}}$ ed. Rio de Janeiro: Forense, 2016.

BARBOSA MOREIRA, José Carlos. Ainda e sempre coisa julgada. In: BARBOSA MOREIRA, José Carlos. Direito Processual Civil (Ensaios e Pareceres). Rio de Janeiro: Borsoi. 1971. p.

BARBOSA MOREIRA, José Carlos. Considerações sobre a chamada relativização da coisa julgada material. In: DIDIER JUNIOR, Fredie (org.). Relativização da coisa julgada. $2^{\mathrm{a}}$ ed. Salvador: Juspodivm, 2008.

BARBOSA MOREIRA, José Carlos. Questões prejudiciais e coisa julgada. Rio de Janeiro: Borsoi, 1967.

BARBOSA MOREIRA, José Carlos. Questões prejudiciais e questões preliminares. In: BARBOSA MOREIRA, José Carlos. Direito Processual Civil (Ensaios e Pareceres). Rio de Janeiro: Borsoi, 1971. p.

BRASIL. Constituição da República Federativa do Brasil de 1988. Brasília. 05 out. 1988.

Disponível

em: 
<http://www.planalto.gov.br/ccivil_03/constituicao/constituicao.htm>. Acesso em: 02 abr. 2019.

BRASIL. Decreto-Lei n. 1.608, de 18 de setembro de 1939. Código de Processo Civil. Rio de Janeiro. 18 set. 1939. Disponível em: $<$ http://www.planalto.gov.br/ccivil_03/decreto-lei/19371946/Del1608.htm> Acesso em: 10 mar. 2019.

BRASIL. Decreto-Lei n. 4.657, de 04 de setembro de 1942. Lei de Introdução às Normas do Direito Brasileiro. Rio de Janeiro, 04 set. 1942. Disponível em: $<$ http://www.planalto.gov.br/ccivil_03/DecretoLei/Del4657compilado.htm> Acesso em: 25 abr. 2019.

BRASIL. Exposição de Motivos do Código de Processo Civil elaborada pela Comissão de Juristas instituída pelo Ato do Presidente do Senado Federal. Disponível em: <https://www2.senado.leg.br/bdsf/bitstream/handle/id/512422/001041135.p df> Acesso em: 10 mai. 2019.

BRASIL. Lei n. 5.869, de 11 de janeiro de 1973. Código de Processo Civil. Brasília. 11 jan. 1973. Disponível em: < http://www.planalto.gov.br/ccivil_03/leis/15869impressao.htm>. Acesso em 15 abr. 2019.

BRASIL. Lei 8.078, de 11 de setembro de 1990. Código de Defesa do Consumidor. 11 set. $1990 . \quad$ Disponível em: 
<http://www.planalto.gov.br/ccivil_03/LEIS/L8078.htm> Acesso em: 20 de ab. de 2019.

BRASIL. Lei n. 9.099, de 26 de setembro de 1995. Brasília, 26 set. 1995. Disponível em: <http://www.planalto.gov.br/ccivil_03/Leis/L9099.htm> Acesso: 14 mai. 2019.

BRASIL. Lei n. 10.406, de 10 de janeiro de 2002. Código Civil. Brasília, 10 jan. $2002 . \quad$ Disponível em: <http://www.planalto.gov.br/ccivil_03/LEIS/2002/L10406.htm> Acesso em: 20 de abr. de 2019.

BRASIL. Lei n. 13.105, de 16 de março de 2015. Código de Processo Civil. Brasília, 16 mar. $2015 . \quad$ Disponível em: <http://www.planalto.gov.br/ccivil_03/_ato20152018/2015/lei/113105.htm>. Acesso em: 15 abr. 2019.

BRASIL. Supremo Tribunal Federal. AgRg no RE 592.912/RS. Relator Ministro Celso de Mello. julgado em 03.04.2012. Dje em 22.11.2012. Disponível em: <https://stf.jusbrasil.com.br/jurisprudencia/22869958/agregno-recurso-extraordinario-re-592912-rs-stf/inteiro-teor111144855 ?ref=juris-tabs>. Acesso em: 20 abr. 2019.

BRASIL. Superior Tribunal de Justiça. Resp n. 1.155.793. Relatora Ministra Isabel Gallotti. julgado em 01.10.2013. DJe de 11.10.2013. Disponível em: <https://stj.jusbrasil.com.br/jurisprudencia/24256385/recurso-especial-resp- 
1155793-df-2009-0166170-7-stj/inteiro-teor-24256386?ref=juris-tabs> Acesso em: 20 de abr. de 2019.

BRASIL. Supremo Tribunal Federal. RE 363.889. Relator Ministro Dias Toffoli. julgado em 02.06.2011. Dje em 15.12.2011. Disponível em: $<$ https://stf.jusbrasil.com.br/jurisprudencia/20998282/recursoextraordinario-re-363889-df-stf>. Acesso em: 20 abr. 2019.

BUENO, Cassio Scarpinella. Curso sistematizado de direito processual civil: Procedimento comum ordinário e sumário. v. 2. $5^{\text {a }}$ ed. São Paulo: Saraiva, 2012.

BUENO, Cassio Scarpinella. Curso sistematizado de direito processual civil: Procedimento comum ordinário e sumário. v. 2. $7^{\mathrm{a}}$ ed. São Paulo: Saraiva, 2014.

CABRAL, Antonio do Passo. Coisa julgada e preclusões dinâmicas: entre continuidade, mudança e transições de posições processuais estáveis. $2^{\mathrm{a}} \mathrm{ed}$. Salvador: Juspodivm, 2014.

CABRAL, Antonio do Passo. Coisa julgada. In: WAMBIER, Teresa Arruda Alvim et al (coord.). Breves comentários ao Novo Código de Processo Civil. São Paulo: Revista dos Tribunais, 2015.

CÂMARA, Alexandre Freitas. O novo Processo Civil Brasileiro. $2^{\mathrm{a}}$ ed. São Paulo: Atlas, 2016. 
CANOTILHO, José Joaquim Gomes. Direito Constitucional. $7^{\mathrm{a}}$ ed. Coimbra: Almedina, 2003.

CHIOVENDA, Giuseppe. Cosa giudicata e preclusione: Saggo di dirrito processuale civile. v. 3. Milano: Giuffré, 1993.

CRAMER, Ronaldo. Ação rescisória por violação da norma jurídica. São Paulo: 2010. 191 p. Dissertação de Mestrado em Direito na Pontifícia Universidade Católica de São Paulo.

DIDIER JUNIOR, Fredie. BRAGA. Paula Sarno. OLIVEIRA. Rafael Alexandria de. Curso de Direito Processual Civil: Teoria da Prova, Direito Probatório, Decisão, Precedente, Coisa julgada e Tutela Provisória. v. 2.13 ed. Salvador: Juspodivm, 2018.

DIDIER JUNIOR, Fredie. Curso de Direito Processual Civil: Introdução ao Direito Processual Civil, Parte Geral e Processo de Conhecimento. v. 1. $18^{\mathrm{a}}$ ed. Salvador: Juspodivm, 2016.

DIDIER JUNIOR, Fredie. Coisa julgada. In: CABRAL, Antonio do Passo; CRAMER, Ronaldo. Comentários ao Novo Código de Processo Civil. $2^{\mathrm{a}} \mathrm{ed}$. Rio de Janeiro: Forense, 2016.

DINAMARCO, Cândido Rangel. Instituições de direito processual civil. v. 3. $7^{\mathrm{a}}$ ed. São Paulo: Malheiros, 2017. 
DINAMARCO, Cândido Rangel. Instituições de direito processual civil. v. 2. $4^{\mathrm{a}}$ ed. São Paulo: Malheiros, 2004.

DONIZETTI, Epídio. Novo Código de Processo Civil Comentado. $3^{\mathrm{a}}$ ed. São Paulo: Atlas, 2018.

Enunciados aprovados na I Jornada de Direito Processual Civil do Conselho da Justiça Federal. ago. 2017. Disponível em: <https://flaviotartuce.jusbrasil.com.br/noticias/495129671/enunciadosaprovados-na-i-jornada-de-direito-processual-civil-do-conselho-da-justicafederal-agosto-de-2017> Acesso em: 20 de mai. 2019

FABRÍCIO, Adroaldo Furtado. A ação declaratória incidental. $3^{\mathrm{a}} \mathrm{ed}$. Rio de Janeiro: Forense, 1996.

FOCHINI, Gaetano. La pregiudizialitá nel processo penale. Milano: La stampa moderna, 1942.

FÓRUM PERMENTE DE PROCESSUALISTAS CIVIL (FPPC). Enunciados do Fórum Permanente de Processualistas Civis. Disponível em: $<$ https://institutodc.com.br/wp-content/uploads/2017/06/FPPC-Carta-deFlorianopolis.pdf> Acesso em: 10 mai. 2019.

GIDI, Antonio; TESHEINER, José Maria Rosa; PRATES, Marília Zanella. Limites objetivos da coisa julgada no projeto de Código de Processo Civil. 
Revista do Processo. v. 194. São Paulo: Revista dos Tribunais, abr. 2011. p. $101-138$.

GRECO FILHO, Vicente. Direito processual civil brasileiro. v. 2. $16^{\mathrm{a}}$ ed. São Paulo: Saraiva, 2003.

GRINOVER, Ada Pelegrini. Ação declaratória incidental. São Paulo: Revista dos Tribunais, 1972.

LEITE, Clarisse Frechiani Lara. Prejudicialidade no processo civil. São Paulo: Saraiva, 2008.

LIEBMAN, Enrico Tullio. Efícácia e autoridade da sentença e outros escritos sobre a coisa julgada (com aditamentos relativos ao direito brasileiro). $2^{\mathrm{a}}$ ed. Rio de Janeiro: Forense, 1981.

MARINONI, Luiz Guilherme; ARENHART, Sergio Cruz; MITIDIERO, Daniel. Código de Processo Civil Comentado. $3^{\mathrm{a}}$ ed. São Paulo: Revista dos Tribunais, 2017.

MARINONI, Luiz Guilherme; ARENHART, Sérgio Cruz; MITIDIERO, Daniel. Novo Curso de Processo Civil: Tutela de direitos mediante procedimento comum. v. 2. $2^{\mathrm{a}}$ ed. São Paulo: Revista dos Tribunais, 2015. 
MARINONI. Luiz Guilherme. Coisa julgada sobre questão, inclusive em benefício de terceiro. Revista do Processo. vol. 259. ano 41. São Paulo: Revista do Tribunal, set. 2016. p. 91-116.

MARINONI, Luiz Guilherme. O princípio da segurança dos atos jurisdicionais (A questão da relativização da coisa julgada material). In: DIDIER JUNIOR, Fredie (org.). Relativização da coisa julgada. $2^{\mathrm{a}}$ ed. Salvador: Juspodivm, 2008. p. 264

MATTOS, Sérgio. Resolução de questão prejudicial e coisa julgada: primeiras linhas sobre o art. 503, $\S 1^{\circ} \mathrm{e} 2^{\circ}$, do CPC/2015. In: Coisa Julgada e outras estabilidades processuais. DIDIER JUNIOR, Fredie; CABRAL, Antônio do Passo (coord.). Salvador: Juspodivm, 2018. p. 207-230.

MEDINA, José Miguel Garcia. Novo Código de Processo Civil comentado: Com remição e notas comparativas ao CPC/1973. $5^{\text {a }}$ ed. São Paulo: Revista dos Tribunais, 2017.

MENESTRINA, Francesco. La pregiudiciale nel processo civile. Milano: A. Giuffré, 1963.

MENEZES, Lucas. A coisa julgada e as questões incidentais no novo Código de Processo Civil. In: Coisa julgada e outras estabilidades processuais. DIDIER JUNIOR. Fredie; CABRAL. Antônio do Passo (coord.). Salvador: Juspodvim, 2018. p. 231-258. 
NERY JUNIOR, Nelson; NERY, Rosa Maria de Andrade. Código de Processo Civil Comentado. 16 a ed. São Paulo: Revista dos Tribunais, 2016.

NEVES, Celso. Coisa Julgada Civil. São Paulo: Revista dos Tribunais, 1971.

NEVES, Daniel Amorim Assumpção. Manual de Direito Processual Civil. $9^{a}$ ed. Salvador: Juspodivm, 2017.

NEVES, Daniel Amorim Assumpção. Novo Código de Processo Civil Comentado. $3^{\text {a }}$ ed. Salvador: Juspodivm, 2018.

RAMINA DE LUCCA, Rodrigo. Os limites objetivos da coisa julgada no Novo Código de Processo Civil. Revista do Processo. v. 252. ano 41. São Paulo: Revista dos Tribunais, fev. 2016. p. 79 - 110.

REDONDO, Bruno Garcia. Questões prejudiciais e limites objetivos da coisa julgada no novo CPC. Revista do Processo. vol. 248. ano 40. São Paulo: Revista Tribunais, out. 2015. p. $43-67$.

REICHELT, Luiz Alberto. Decisão sobre questões prejudiciais de mérito e direito fundamental à intangibilidade da coisa julgada material no novo Código de Processo Civil. Revista de processo. vol. 259. ano 41. p. 896. São Paulo: Revista dos Tribunais, set. 2016. p. 81- 96.

SAMPAIO, Marcos Vinicius de Abreu. Da intervenção de Terceiros. In: WAMBIER, Teresa Arruda Alvim et al (coord.). Breves comentários ao 
Novo Código de Processo Civil. EDIÇÃO. São Paulo: Revista dos Tribunais, 2015.

SAMPIETRO, Luiz Roberto Hijo. Primeiras reflexões sobre a possibilidade de a coisa julgada atingir questões prejudiciais no Novo Código de Processo Civil. Revista de Processo. vol. 253. ano 41. São Paulo: Revista dos Tribunais, mar. 2016. p. 185-207.

SHWAB, Karl Heinz. El objeto litigioso em el processo civil. Buenos Aires: EJEA, 1968.

SILVA, Ovídio A. Baptista da. Curso de Processo Civil. Processo de Conhecimento. v. 1. $3^{\circ}$ ed. São Paulo: Revista dos Tribunais, 2000.

SILVA, Ovídio A. Baptista da; GOMES, Fábio Luiz. Teoria geral do Processo Civil. $3^{\text {a }}$ ed. São Paulo: Revista dos Tribunais, 2002.

TALAMINI, Eduardo. Questões prejudiciais e coisa julgada. São Paulo, 2016. Disponível em <https://www.migalhas.com.br/dePeso/16,MI235860,101048Questoes+prejudiciais+e+coisa+julgada> Acesso em : 10 abr. 2019.

TALAMINI, Eduardo; WAMBIER, Luiz Rodrigues. Curso Avançado de Processo Civil: Teoria geral do processo e processo de conhecimento. v. 1. $13^{\mathrm{a}}$ ed. São Paulo: Revista dos Tribunais, 2013. 
THEODORO JÚNIOR, Humberto. Curso de Direito Processual Civil: Teoria geral do direito processual civil, processo de conhecimento e procedimento comum. v. I. 59 $9^{\mathrm{a}}$ ed. Rio de Janeiro: Forense, 2018.

WAMBIER, Teresa Arruda Alvim. O que é abrangido pela coisa julgada no Direito Processual Civil Brasileiro: a norma vigente e as perspectivas de mudança. Revista de Processo. ano 39. v. 230. São Paulo: Revista dos Tribunais, abr. 2014. p. 75-89.

ZAVASCKI, Teoria Albino. Eficácia das sentenças na jurisdição constitucional. Porto Alegre, ago. 2000. 